DIATOMS AS INDICATORS OF HISTORICAL MACROPHYTE BIOMASS IN FLORIDA LAKES

By

THOMAS JAMES WHITMORE

A DISSERTATION PRESENTED TO THE GRADUATE SCHOOL OF THE UNIVERSITY OF FLORIDA IN PARTIAL FULFILLMENT OF THE REQUIREMENTS FOR THE DEGREE OF DOCTOR OF PHILOSOPHY

UNIVERSITY OF FLORIDA 


\section{ACKNOWLEDGMENTS}

I thank Daniel E. Canfield, Jr. for suggesting the concept of this study in constructive criticisms he offered during my master's defense. Dan's challenge provided me with motivation: I chose this topic because I was determined to show him I could resolve the problem. Mark Hoyer and Christine Horsburgh were responsible for collection and management of macrophyte data, and Mark was especially helpful in providing me with this information. The Florida Museum of Natural History provided the vehicles, boats, and equipment for field work. Brian Rood, J. Daniel Bryant and Dennis Crumby assisted in the field. Silvia Ferguson gave much time and hard work in field assistance, and has been a constant source of support throughout this study.

I am grateful to Claire Schelske, Marty Fleisher, and Arthur Peplow for radionuclide assay of samples used to calculate bulk sediment accumulation rates. I thank Douglas Turley for the time and computer expertise he offered for data management. Paul Zimba gave generous assistance in computer programming during his personal time, making it possible for me to use the CANOCO statistical package. Dana Griffin provided funds for mainframe computing. Martha Love and Sarah E. Whitmore kindly helped with manuscript preparation. 
This dissertation work was begun under the guidance of Edward S. Deevey, Jr., my major professor for more than 9 years. Ed's death in November 1988 was a blow to many academic disciplines, and a sad personal loss of which I am especially cognizant at this time. I have benefitted from Frank Nordlie's particulalry competent guidance through the completion of my studies. Claire Schelske generously provided the space, resources and financial support that allowed me to complete my graduate work. Joseph S. Davis and Ronald G. Wolff have been supportive members of my graduate committee for many years. It is largely due to Ron's encouragement that I pursued graduate studies at the University of Florida. No list of acknowledgements for my graduate work would be complete without expressing sincere thanks for all manner of support and encouragement to Mark Brenner, my colleague of $11-1 / 2$ years who introduced me to paleolimnology. 


\section{TABLE OF CONTENTS}

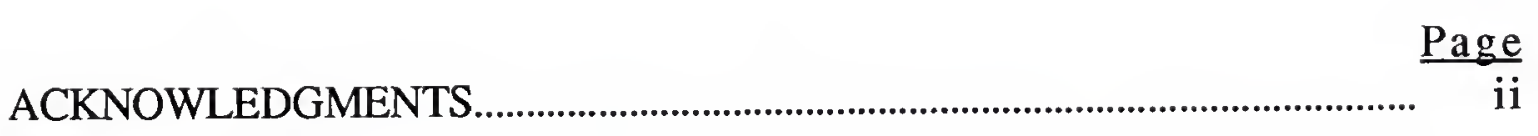

ABSTRACT

$\mathrm{vi}$

\section{CHAPTER}

1

INTRODUCTION

The Concept of Trophic State in Lakes....................................... 1

Macrophytes and the Lake Ecosystem........................................ 4

The Relationship of Macrophytes With Epiphyton............... 11

Methods for Reconstructing Historical Macrophyte

Communities..................................................................... 15

Diatom Methods in Paleolimnology............................................. 16

Effects of Spatial Variation on Diatom Assemblages............ 27

Purpose.................................................................................................. 29

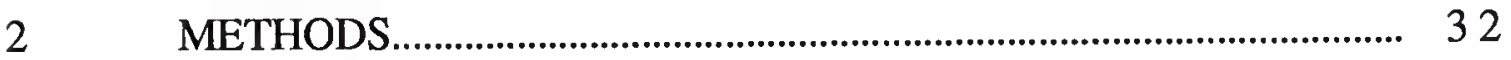

Collection of Sediment Samples.................................................. 32

Laboratory Analyses....................................................................... 33

Quantifying Macrophyte Presence............................................. 36

Water Chemistry Data................................................................... 38

Statistical Analyses........................................................................ 38

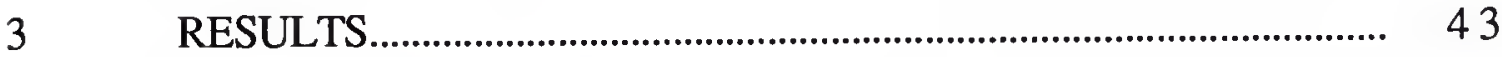

Results of Cluster Analyses.......................................................... 61

Results of Principal Components Analyses............................ 68

Results of Stepwise Multiple Regression.................................. 76

Results of Canonical Correspondence Analyses.................... 83

A New Predictive Model for Water-Column Total P......... 85 Assessing Confoundedness in the Water-Column Total

P Predictive Model........................................................... 88 


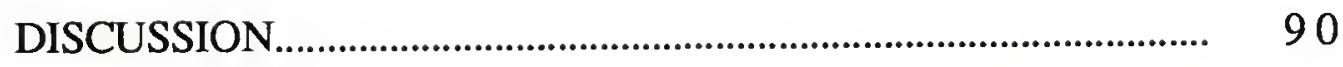

Dominant Environmental Variables and Scale of Analysis.

Response of Periphyton to Water-Column Nutrients...... 93

Recommended Predictive Models for Macrophyte

Variables....................................................................... 95

Applying Predictive Models to Obtain Historical TSI

Estimates

APPENDIX 1. 101

APPENDIX 2. 102

APPENDIX 3. 109

APPENDIX 4 116

APPENDIX 5.

118

APPENDIX 6

120

BIBLIOGRAPHY

123

BIOGRAPHICAL SKETCH. 


\begin{abstract}
Dissertation Presented to the Graduate School of the University of Florida in Partial Fulfillment of the Requirements for the Degree of Doctor of Philosophy
\end{abstract}

\title{
DIATOMS AS INDICATORS OF HISTORICAL MACROPHYTE BIOMASS IN FLORIDA LAKES
}

By

Thomas James Whitmore

May 1991

Chairman: Frank G. Nordlie

Major Department : Zoology

Macrophytes represent an important component of primary production in lakes that is usually ignored in trophic state classification. Trophic classifications traditionally emphasize watercolumn nutrient concentrations and phytoplankton biomass.

Predictive models have been developed from diatom assemblages to assess historical changes in lake trophic state, but these models usually infer water-column total $\mathrm{P}$ or chlorophyll $a$ values and thus also ignore macrophyte production. Lake-sediment core samples often indicate former periods of low trophic state, although these periods may instead represent low water-level events that periodically occur in Florida lakes. Because macrophyte biomass is negatively correlated with water-column nutrients, macrophyte biomass may have been high at times when nutrient inferences suggest that lakes were unproductive. 
The purpose of this study was to develop predictive models for inferring historic macrophyte biomass using diatoms, and to incorporate those models into a scheme that permits a more complete assessment of former lake trophic state than do models based solely on water-column nutrient concentrations.

Subfossil diatom assemblages were analyzed from the surface sediments of 29 Florida lakes covering a range of macrophyte abundance. Trophic-state, $\mathrm{pH}$, and specific conductance formed an environmental gradient that was the principal influence on diatom communities in the limnologically diverse set of lakes. The planktonic proportion of the diatom community was positively correlated with trophic state, whereas the periphytic proportion was negatively correlated with trophic state. Sedimentary diatom concentrations, however, showed that both of these life-form communities had a positive response to increase in water-column nutrients.

Multivariate models are presented that permit estimates of former macrophyte biomass from fossil diatom assemblages. The $\mathrm{kg}$ of $P$ contained in once-living macrophyte biomass can be estimated using a mean percent $\mathrm{P}$ value for macrophyte taxa. This mass of $\mathrm{P}$ divided by lake volume yields a concentration that can be added to limnetic $P$ inferences obtained from diatom predictive models to estimate the potential total $\mathrm{P}$ content of the water column (WCP) Trophic state index values calculated with historic WCP will reflect both former macrophyte and phytoplankton aspects of trophic state. 


\section{CHAPTER 1}

\section{INTRODUCTION}

\section{The Concept of Trophic State in Lakes}

Primary productivity in lakes can be defined as the rate at which new organic matter is formed by photosynthesis in autotrophs such as phytoplankton and macrophytes. Annual productivity is typically expressed as the number of grams of carbon fixed per unit of lake surface area per year. Lake productivity, however, has been more traditionally thought of in conceptual terms referred to as trophic state, and typologically described using categories ranging from ultraoligotrophic at the low end of productivity to hypereutrophic at the high end (cf. Shannon and Brezonik 1972).

Several trophic state indices (TSI) have been developed that permit numerical expression of trophic state using biological, physical and chemical characteristics. Shannon and Brezonik (1972), for instance, used principal components analysis to reduce seven variables including chlorophyll $a(\mathrm{Chl} a)$, primary productivity, and total $\mathrm{P}$ to a single variable that described the trophic status of lakes. Although it was inclusive, this TSI has been regarded as cumbersome, especially because of the difficulty in obtaining primary productivity values. Carlson (1977) sought a single, easily obtained measure to describe lake trophic state, and he selected 
Secchi depth, a convenient variable that reflected phytoplankton standing crop in many lakes. Carlson scaled his TSI with the intention that a ten-unit increase in TSI would be equivalent to a doubling of algal biomass, but his index failed to relate in a uniform way to Chl $a$. Carlson calibrated his TSI to limnetic Chl $a$ and total P for a set of north-temperate lakes and developed subindices to permit expression of TSI from these latter two variables.

Kratzer and Brezonik (1981) later modified Carlson's approach by constructing a subindex expressing TSI from water-column total $\mathrm{N}$ concentrations after observing $\mathrm{N}$ limitation in several Florida lakes located on phosphatic limestones. They proposed an averaged subindex that used mean TSI values based on Chl $a$ and Secchi depth, and the lesser of the two TSI values based on total P and total $\mathrm{N}$.

Baker et al. (1981) observed different relationships between Secchi depth, total P and Chl $a$ in Florida lakes than Carlson (1977) observed in north-temperate lakes. Huber et al. (1982), therefore, constructed a new TSI for Florida lakes using the Florida Lakes Data Base, a large data set that is maintained at the Water Resources Research Center at the University of Florida.

Huber et al. based their TSI on Chl $a$, a more direct measure of phytoplankton biomass than Secchi depth, and they retained Kratzer and Brezonik's total $\mathrm{N}$ and averaged subindex approach because of $\mathrm{N}$ limitation in some Florida lakes. Huber et al. described lakes with total $\mathrm{N} /$ total $\mathrm{P}$ values $>30$ as $\mathrm{P}$-limited, and calculated averaged TSI (TSI(AVG) for these lakes as the mean of TSIs based on Secchi depth (TSI(SD)), Chl $a$ (TSI(Chl $a)$ and total P (TSI(TP)). Lakes with total $\mathrm{N} /$ total $\mathrm{P}$ values $<10$ were described as $\mathrm{N}$-limited, and $\mathrm{TSI}(\mathrm{AVG})$ was 
calculated as the mean of TSI(SD), TSI(Chl $a$ ) and TSI(TN). Huber et al. regarded lakes with total $\mathrm{N} /$ total $\mathrm{P}$ values between 10 and 30 as nutrient-balanced, and noted that nutrient-Chl $a$ relationships were different in these lakes than in nutrient-limited lakes. They constructed new TSI expressions for total $\mathrm{P}$ (TSI(TPB) and total $\mathrm{N}$ (TSI(TNB) for nutrient-balanced lakes, and defined TSI(AVG) for these lakes as the mean of $\operatorname{TSI}(\mathrm{SD}), \operatorname{TSI}(\mathrm{Chl} a), \operatorname{TSI}(\mathrm{TPB})$ and TSI(TNB). The TSI of Huber et al. is the only TSI developed specifically for use in Florida lakes.

All of the trophic state indices discussed above, however, share in common their bias towards phytoplankton biomass and watercolumn nutrient concentrations as the relevant indicators of primary production in lakes, and they give no importance to the presence of macrophytes. Porcella et al. (1980) constructed a multivariate index based on Carlson's (1977) subindices and included a term derived from percent-area coverage of macrophytes. Because Porcella et al.'s TSI was developed for north-temperate lakes that are P-limited and demonstrate hypolimnetic oxygen deficits during stratification, this TSI might be inappropriate for use in Florida. The macrophyte term also failed to quantify nutrients contained in macrophyte biomass as other TSIs using water-column total $P$ quantify the nutrients contained in phytoplankton biomass.

Canfield et al. (1983a) proposed a new approach to trophic state classification of lakes that gave consideration to nutrients contained in macrophyte biomass as well as to water-column nutrient concentrations. They quantified the amount of $\mathbf{P}$ contained per unit of dry weight in many species of macrophytes from 6 Florida lakes. 
Next they estimated the macrophyte biomass in each lake from the area covered by macrophytes and the macrophyte density in $\mathrm{kg}$ of wet biomass per square meter. This permitted calculation of the $\mathrm{kg}$ of $\mathrm{P}$ contained in macrophyte biomass in each lake and the amount of $P$ that would be released to the water column assuming $100 \%$ death and decomposition of the macrophytes. Dividing this mass of $\mathrm{P}$ by the lake volume yielded a concentration that when added to water column total $\mathbf{P}$ produced an estimate of the potential total $\mathbf{P}$ content of the water column (WCP). This approach provided more realistic estimates of trophic state for lakes such as Fairview in Orange Co., which appeared oligotrophic based on water-column nutrients and Chl $a$, but contained a large standing crop of macrophytes. The estimate of total water-column $P$ content brought this lake to the eutrophic range, which was edaphically consistent with other lakes in the same physiographic region. Recent evidence shows that watercolumn $\mathrm{P}$ concentration in Lake Fairview has increased to the predicted WCP level because of macrophyte removal by grass carp (Canfield pers. comm.). Canfield et al. (1983a) noted that the same approach may be used with $\mathrm{N}$ for lakes that are $\mathrm{N}$-limited.

\section{Macrophytes and the Lake Ecosystem}

Despite the emphasis on water-column nutrients and phytoplankton biomass to characterize lake trophic state, macrophytes are responsible for a substantial amount of the primary production that occurs in many lakes. This is especially the case in Florida because the shallow depths of Florida lakes, the high amounts of insolation and the long growing season are conditions that support 
high macrophyte standing crops (Brenner et al. 1990). Many Florida lakes have high nutrient concentrations because of edaphic reasons or anthropogenic loading (Canfield and Hoyer 1988), and this also stimulates macrophyte production.

\section{Macrophyte Growth Forms}

Macrophyte species are often grouped into growth-form categories that describe whether or not the plants are rooted in sediments and whether they grow laterally in the water or erect and out of the water. Submerged macrophytes are those typically rooted in sediments, growing completely under the water and usually flexible due to a lack of rigid cellular tissue. Myriophyllum heterophyllum Michx., Utricularia purpurea Walt. and Ceratophyllum demersum $\mathrm{L}$. are three examples of submerged taxa native to Florida, while another common taxon, Hydrilla verticillata Royle is an introduced exotic that has proliferated widely. Many submerged taxa, when growing in dense stands, are regarded as nuisance species that have a negative effect on lake recreational uses (Brenner et al. 1990).

Floating-leaved plants can be divided into two categories depending on whether they are rooted in sediments or not. Rooted floating-leaved plants derive most of their nutrients from the sediments (Carignan and Kalff 1980) and often have large peltate leaves growing at the surface where they have access to sunlight and atmospheric $\mathrm{CO}_{2}$ for photosynthesis. Common examples of these taxa found in Florida are Nymphaea spp. (water-lily), Nelumbo lutea (Willd.) Pers. (American lotus), Nuphar luteum (L.) Sibth. \& Smith 
(spadderdock), Nymphoides aquatica (Gmel.) O.Ktze and Brasenia shreberi Gmelin. A second group of floating-leaved taxa are unrooted in sediments and free-floating. These taxa, which include Lemna minor L. (duckweed), Pistia stratiotes L. (water-lettuce) and Salvinia rotundifolia Willd,, obtain their nutrients from the water and exhibit adaptations that keep the plant afloat. Eichhornia crassipes (Mart.) Solms. is a floating-leaved species introduced to Florida, which because of its rapid spread and prolific growth, has become a severe economic and environmental problem (Tarver et al. 1979).

Emergent taxa, which grow erect in shallow aquatic areas and do not depend on the water for support, demonstrate the third growth form in macrophytes. Common examples of these taxa are Typha spp. (cattails), which was the macrophyte with the most extensive areal coverage in a large survey of Florida lakes (Schardt 1983), and Sagittaria latifolia Willd.

Some taxa exhibit growth patterns that are typical of more than one growth-form category. Hydrocotyl umbellata L., for instance, grows mostly as a submerged plant though leaves are frequently emergent in shallow water. Portions of Hydrocotyl mats occasionally break away and are redistributed as floating vegetation. Potamogeton spp. also exhibits extensive lateral submerged growth, but bears some floating leaves at the surface.

\section{Environmental Factors Influencing Macrophyte Distribution}

Many studies have been conducted to determine which environmental factors most affect the distribution and abundance of macrophytes, and many of these studies have come to different 
conclusions. Collins et al. (1987), for instance, compared macrophyte biomass density with 13 different chemical, physical and biological variables at various sites in Lake George, NY. They concluded that water depth was the most important factor affecting macrophyte biomass, and that substrate type and eutrophication status were of secondary importance. Canfield and Hoyer (1988) studied the influence of light and nutrient availability on macrophytes in Florida streams, and they concluded that nutrients do not regulate the abundance of macrophytes. Shading of macrophytes was the most important factor regulating macrophytes in that study, while substrate type, water depth and current velocity had a secondary influence. Jackson and Charles (1988) studied macrophyte species composition in 31 small, unproductive lakes in New York that were low in specific conductance. They concluded that $\mathrm{pH}$ was the regulating factor, that area, slope and substrate composition were of secondary importance, and that macrophyte distribution bore no relation to trophic state indicators. Crowder et al. (1977) concluded that specific conductance was as important a macrophyte determinant as $\mathrm{pH}$ in their study on circumneutral to hardwater lakes. Duarte and Kalff (1990) determined that alkalinity and slope were the most important factors in their study, but they explained the discrepant conclusions between studies as the result of differences in scale of analysis. When macrophytes are compared between lakes in hardwater areas, water chemistry, including specific conductance and trophic state are bound to be important determinants of macrophyte disribution (Duarte and Kalff 1990, Jackson and Charles 1988). Surveys of unproductive, dilute lakes 
cover a small range of difference along the $\mathrm{pH}$-alkalinityconductivity complex, and they are likely to conclude that $\mathrm{pH}$ is the important variable affecting macrophyte distribution (Jackson and Charles 1988). Surveys conducted within one or a few lakes will cover only a small range of water chemisty differences, and site characteristics, such as waves, slope and sediment type, will prove to be the most important determinants (Duarte and Kalff 1990). Within a single lake, wave exposure is likely to be a leading determinant of macrophyte biomass at shallow littoral depths, whereas water transparency will exert more influence at greater depths (Duarte and Kalff 1990).

\section{Effect of Macrophytes on Lake Ecosystem}

Macrophytes seem to exert considerable effects on the nutrient cycling, biology, sedimentation patterns and senescence of the lakes in which they occur. Rooted macrophytes obtain most of their nutrients from lake sediments and thus link the sediments with overlying water (Carpenter 1981). This provides a mechanism for the regeneration of sedimentary nutrients into the water-column. Carignan and Kalff (1982) observed that living macrophytes were responsible for a $2.2 \%$ daily increase in $\mathrm{P}$ that represented a net seasonal input to the littoral zone because the $\mathrm{P}$ was derived from sediments. While $\mathrm{P}$ is not released from living macrophytes at a rapid rate, substantial amounts of nutrients in the macrophyte biomass are released when macrophytes die back and shoots decay. Approximately $75 \%$ of the $\mathrm{P}$ released is in a soluble reactive form, and $\mathrm{P}$ becomes rapidly assimilated by phytoplankton, leading to an 
increase in water-column Chl $a$ (Carpenter and Lodge 1986). Landers (1982) estimated that approximately $18 \%$ of the annual P loading in Lake Monroe, Indiana originated from senescing macrophytes. Carpenter (1981) also concluded that most of the dissolved organic carbon and dissolved total $\mathbf{P}$ in Lake Wingra, Wisconsin was released during decomposition of Myriophyllum spicatum in the littoral zone. Filbin and Barko (1985) have concluded that the release of sedimentary nutrients into the water column by macrophytes may be more significant in lakes than in reservoirs because of the riverine nature of reservoirs.

Macrophytes have several influences on the sedimentation patterns in lakes where they are found. Macrophytes tend to intercept or modify the flow of materials such as sediment from land to the pelagic zone. By reducing water velocity and wave action, macrophytes function as sediment traps in the littoral zone. This effect was shown to be significant in historical changes in sedimentation patterns of Lough Augher, Northern Ireland (Anderson 1990b). When macrophytes die, their biomass increases sedimentary organic matter content and leads to an accretion of littoral sediment that promotes infilling of the lake basin and expansion of emergent vegetation (Carpenter 1981, Carpenter and Lodge 1986). Macrophyte presence in lakes, therefore, accelerates infilling and senescence of lakes.

Macrophytes provide a complex habitat, and their presence leads to an increase in those species commonly found in littoral areas. When macrophytes are present, epiphytic algae proliferate and an increase is observed in epiphytic grazers such as snails (Carpenter 
and Lodge 1986). Zooplankton are abundant in weed beds and the habitat complexity also provides cover and protection for spawning and young fish (Carpenter and Lodge 1986). Dense infestations of submerged macrophytes, nevertheless, have been shown to have a negative effect on the presence of sport fish (Shireman and Maceina 1981).

Conflicting reports have been presented about the effects of eliminating macrophytes in lakes through chemical or biological control. Carpenter and Lodge (1986) stated that because of the macrophyte role in enhancing sedimentary $P$ recycling, an increase in macrophyte standing crop will lead to an increase in phytoplankton standing crop, whereas the long-term effect ( $>3 \mathrm{yrs}$.) of killing macrophytes will lead to a decrease in water-column $\mathrm{N}$ and $\mathrm{P}$ and a decrease in phytoplankton. This positive correlation between macrophyte and phytoplankton standing crop is contrary to the negative relationship reported by Canfield et al. (1984) between the percent of lake volume infested with macrophytes and water-column Chl $a$ for 32 Florida lakes. An increase in water-column $\mathrm{P}$ concentrations and phytoplankton standing crop has been shown following herbicide application to macrophytes in Florida lakes because of nutrient release by the decaying plant material (Richard et al. 1984). An increase in water-column $P$ was also reported following biological control of macrophytes using the grass carp Ctenopharyngodon idella because of nutrient release from feces, although this increase seems less dramatic because of the retention of $\mathrm{P}$ in the fish biomass (Richard et al. 1984, Canfield et al. 1983b, Canfield et al. 1984). 
The Relationship of Macrophytes With Epiphyton

Epiphytic algae growing in macrophyte beds often exhibit high concentrations of biomass and are responsible for a significant proportion of the primary production in a lake. Allen and Oceuski (1981), for instance, determined that algal epiphytic production in Lake Ohrid, Yugoslavia was higher than the production they observed in littoral or pelagic algae. Cattaneo and Kalff (1980) observed that the epiphytic algae in eutrophic portions of Lake Memphremagog, Quebec fixed more carbon than macrophytes did throughout the growing season. Fontaine and Ewel (1981) estimated that macrophytes and their associated epiphytes were responsible for $56 \%$ of the gross production in Little Lake Conway, Florida.

The question of macrophytes as a nutrient source for their epiphytic algae has been a much-debated issue often referred to as the "neutral substrate hypothesis" in the literature. Cattaneo and Kalff (1979) observed no significant difference in epiphytic production on Potamogeton richardsonii and artificial plants made of plastic. They concluded that macrophytes functioned as neutral support structures. Carignan and Kalff (1982) studied epiphytic algae growing on fully 32P labelled Myriophyllum spicatum and concluded that epiphytes derived only $3.4-9.0 \%$ of their $\mathrm{P}$ from the labelled macrophytes, and that macrophytes were more important to epiphytes for support than as a P source. Gough and Gough (1981) took issue with Cattaneo and Kalff (1979), and cited Hutchinson's (1975) statements that macrophytes release by-products of nutrient assimilation, photosynthates and inorganic nutrients. They argued 
that although some macrophytes may be neutral hosts, others affect epiphytic production or community composition. Cattaneo and Kalff (1981) replied that epiphytic biomass was mostly related to the surface area of the substrate on which the epiphytes grow, and that water chemistry exhibits a greater influence than macrophytes on epiphytic production.

Recent studies by Burkholder and Wetzel (1990) seem to offer a more definitive explanation of macrophyte influence on epiphytes. They measured alkaline phosphatase (APA), an enzyme that catalyzes hydrolysis of organic $\mathrm{P}$ compounds to release orthophosphate, in epiphyton growing on natural and artificial plants. They observed, as did Cattaneo and Kalff (1979), that APA concentrations were higher in epiphyton growing on artificial substrates than they were in epiphyton growing on macrophytes. Burkholder and Wetzel concluded that epiphyton on artificial substrates are P-limited and synthesize APA to provide a P source, although the epiphyton growing on macrophytes were not P-limited because of nutrient release by the macrophytes.

Epiphyton can in turn exert effects that influence the growth of their macrophyte hosts. Nutrients are usually in abundant supply to rooted macrophytes, and macrophytes generally do not seem to compete with epiphyton for this resource. When epiphyton biomass is high, however, epiphyton may shade their macrophyte hosts (Eminson and Moss 1980). Filbin and Barko (1985) observed that epiphytic biomass in Eau Galle Reservoir, Wisconsin comprised up to $33 \%$ of the macrophyte and epiphyte biomass, and they concluded that epiphyton may have limited macrophyte growth by light 
attenuation. Sand-Jenson and Sondergaard (1981) studied phytoplankton and epiphyton shading effects on macrophytes in Danish lakes. In oligotrophic, silicate-poor lakes, the water was responsible for most of the light attenuation. Epiphyton were responsible for $50 \%$ of the light attenuation to macrophytes in oligotrophic, silicate-rich lakes receiving $N$ supply. In a lake that had a high nutrient supply, they determined that epiphytes were responsible for $86 \%$ of the light attenuation to macrophytes. Sand-Jensen and Sondergaard concluded that the shading effects that epiphytes exert on macrophytes becomes a decisive factor limiting depth distribution of macrophytes in lakes with high nutrient supply.

Substrate Specificity and Growth Forms of Periphyton

Some studies have indicated a high degree of substrate specificity by epiphytic and periphytic diatoms. Round (1956) characterized diatom taxa growing on plants (epiphytic) as "attachment" types mostly of the genera Achnanthes, Cymbella and Epithemia, whereas diatoms found on sediments (epipelic) were actively motile and unattached, including the genera Navicula, Amphora and Diploneis. Round noted, however, that diatom taxa growing on stones (epilithic) were similar to epiphytic diatoms. Siver (1978) observed that the diatom genera Achnanthes, Cocconeis and Eunotia were the most abundant taxa growing on Potamogeton robinsii. Blindow (1987) stated that the composition of epiphyton on Potamogeton and Chara was different than the epiphytic composition on Nitellopsis that was heavily marl-encrusted. Eminson and Moss (1980) observed that host specificity of periphyton was greater in 
oligotrophic lakes because of the importance of macrophyte nutrient loss to epiphytes, whereas host specificity was less pronounced in mesotrophic and eutrophic lakes because of the greater effect of water-column nutrients on periphytic taxa.

Several studies have demonstrated the importance of diatom growth form to patterns of colonization and physical structure of epiphytic diatom communities. Achnanthes and Cocconeis are solitary cells that lie adnate to the substrate and colonize horizontally, and these genera are usually the initial colonizers on new substrate (Robinson and Rushforth 1987). Later colonizers must contend with space limitations, and genera such as Gomphonema and Cymbella are at an advantage because they grow on long stalks and colonize in a vertical orientation (Roemer et al. 1984, Robinson and Rushforth 1987). This upward expansion of the epiphytic community improves light and nutrient availability for taxa in the higher tiers (Hudson and Legendre 1987), though some adnate forms below such as Cocconeis placentula var. euglypta (Ehr.) Cl. exhibit shade tolerance (Robinson and Rushforth 1987). Swift-moving taxa capable of complex movements including Nitzschia and Navicula can be observed within the community matrix (Hudson and Legendre 1987). As the thickness of periphyton on the substrate becomes too great, cells on the outer tiers are subject to loss by grazing or sloughing off by currents (Roemer et al. 1984, Hudson and Legendre 1987).

Sloughed off periphytic taxa can become part of the planktonic drift and are then referred to as tychoplanktonic (Lowe 1974). 


\section{Methods for Reconstructing Historical Macrophyte Communities}

Historical macrophyte presence has been traditionally determined from lake sediments by methods that do not yield quantitative estimates of standing crop. Macrophyte presence has been assessed historically from macrophyte remains, pollen and seeds that are found in lake sediment. Davis (1985) studied historical macrophyte presence in upper Chesapeake Bay and summarized many of the biological and diagenetic factors that obscure accurate reconstruction of former macrophyte communities. Seed preservation is poor in some taxa (e.g. Vallisneria and Potamogeton) and seed dispersal is poor in others (e.g. Myriophyllum) leading to under-representation of these taxa in sediments. Pollen and seed production is variable among species of macrophytes (Yeo 1966, Birks 1980), and plants producing larger quantities of these may be over-represented in the sedimentary record. Seeds and pollen also may be unreliable indicators of macrophyte standing crop because a large number of species reproduce vegetatively by budding, fragmentation and by plants arising from stolons and rhizomes (Tarver et al. 1979).

Seed representation in the sedimentary record may be affected by differential transport and palatability (Birks 1980). Birks (1973) and Watts (1978) have shown that seed dispersal is often localized for macrophyte taxa. Dispersal patterns, therefore, can cause a high degree of spatial variability of macrophyte indicators in lake sediment. Sampling from many littoral sediment cores is required to obtain a reliable reconstruction of macrophyte history. 
To summarize, traditional methods of macrophyte community reconstruction tend to over-represent, under-represent or miss entire portions of the macrophyte community. No single method has been developed that will provide reasonably accurate quantitative estimates of historical macrophyte standing crop.

\section{Diatom Methods in Paleolimnology}

\section{Some Quantitative Diatom Methods Used in $\mathrm{pH}$ Reconstructions}

Most quantitative work using diatoms to reconstruct past limnological conditions has been concerned with lake acidification due to anthropogenically induced acid precipitation. The large number of lake acidification studies recently funded (Davis 1987) indicates that lake acidification has occupied an important place on the agenda of national and international environmental concerns. The high costs of implementing more rigid air pollution standards necessitated statistical rigor to determine if atmospheric loadings of sulfur and $\mathrm{N}$ oxides were having significant fallout effects on aquatic ecosystems. As a consequence, lake acidification studies received priority funding and were numerous. Davis (1987) reviewed many such studies that used diatoms to infer historical $\mathrm{pH}$ trends.

The earliest quantitative index relating diatom assemblages to $\mathrm{pH}$ of lakewater was the $\alpha$ index described by Nygaard (1956), a ratio of acidic to alkaline diatoms in a sample based on the $\mathrm{pH}$ autecological classifications (Hustedt 1937-38) of the individual taxa. Renberg and Hellberg (1982) developed the somewhat more sophisticated index $\mathrm{B}$ that was also a ratio of the percentage of diatoms in $\mathrm{pH}$ autecological categories. These authors regressed log- 
transformed index $\mathrm{B}$ values with $\mathrm{pH}$ for a set of 30 Swedish lakes and produced a model with which they assessed lake acidification due to atmospheric deposition in Sweden. Index B is somewhat statistically dubious, however, because coefficients for the autecological terms could not have been calculated by a simple linear regression between $\mathrm{pH}$ and $\log$ index $\mathrm{B}$ as indicated by Renberg and Hellberg (Whitmore 1989).

Cluster analysis has been used to identify diatom assemblages characteristic of various $\mathrm{pH}$ conditions (e.g. Davis and Anderson 1985). Charles (1985) used cluster analysis to group diatom species with similar $\mathrm{pH}$ requirements and he performed a multiple regression of these clusters with $\mathrm{pH}$ values of 38 Adirondack lakes. His model explained approximately $90 \%$ of the variance in $\mathrm{pH}$ in his calibration data set.

Davis and Berge (1980) performed a stepwise multiple regression of 33 taxa in a set of Norwegian lakes and produced a model consisting of 7 taxa that explained $93 \%$ of the variance in $\mathrm{pH}$ (unadjusted $\mathrm{R}^{2}$ ). Dixit and Evans (1986) have shown, however, that particularly in lakes with spatial variability in diatom assemblages, the use of indicator assemblages rather than individual taxa in predictive models will greatly reduce the error term. Hustedt's (1937-38) $\mathrm{pH}$ autecological categories have also been used in multiple regression equations to develop $\mathrm{pH}$ predictive models based on diatom assemblages (Davis and Berge 1980, Charles 1984, 1985).

Ordination techniques, which reduce the number of diatom variables in a model, have been used to construct $\mathrm{pH}$ predictive equations. Principal components analysis is an indirect ordination 
technique that was used to develop models for assessing lake acidification in Maine and Norway (Davis and Berge 1980, Davis and Anderson 1985). Davis and Anderson (1985) found that principal component models were less sensitive than multiple regression models using individual taxa to variation in the frequencies of taxa caused by environmental factors other than pH. Van dam et al. (1980) also used a principal components procedure to calibrate diatom models and assess the effects of acid precipitation on Dutch moorland pools.

Reciprocal averaging (RA) is another indirect ordination technique that has been used in diatom-based models. Charles (1985) used reciprocal averaging to ordinate diatom data and he correlated RA axes with environmental variables in a set of Adirondack lakes. $\mathrm{pH}$ was a primary determinant of diatom assemblage composition in that set of lakes and a regression equation predicting $\mathrm{pH}$ from Charles' first RA axis explained $90 \%$ of the variance in $\mathrm{pH}$. In other environmental applications, ServantVildary and Roux (1990) have used reciprocal averaging to determine the effects of ionic elements on diatom species composition in saline lakes of the Bolivian Altiplano.

Canonical correspondence analysis (CANOCO) is a direct ordination technique that has been used in $\mathrm{pH}$ reconstructions to define axes that are combinations of taxa responding directly to $\mathrm{pH}$. The axes have then been regressed with $\mathrm{pH}$ and the resulting models used to document historical trends in lake acidification. Battarbee et al. (1988), for example, used CANOCO to assess the acidification of 
Scottish lochs and their recovery following abatement of atmospheric sulfate emissions in the United Kingdom.

\section{Diatom Methods for Reconstructing Trophic State}

Historical trophic state studies generally have not received the degree of quantitative treatment that studies of lake acidification have. Diatom/trophic reconstructions have often relied heavily on autecological information of specific taxa for qualitative interpretation of diatom percentage diagrams from lake sediment cores. Brugam (1978), for instance, documented the eutrophication of Linsley Pond in Connecticut and Bradbury (1975) used diatoms to interpret the history and eutrophication of Minnesota lakes. Battarbee (1978) observed the influence of land use and sewage effluent on the eutrophication of Lough Neagh, Northern Ireland. Håkansson (1982) presented an excellent ecological analysis of the diatom flora from Håvgårdssjön in Sweden and documented eutrophication after 1900 due to agricultural activity. Qualitative studies have provided understanding of gross trends in the trophic trajectory of lakes because of climatic patterns and anthropogenic influence, but they have lacked ability to discern subtle trophic differences, assess rates of change or demonstrate statistical significance.

Ratios have been proposed that quantitatively describe lake productivity using the percentages of diatom species separated at high taxonomic levels. Nygaard's (1949) C/P index was a ratio of the number of valves in the diatom orders Centrales and Pennales. High $\mathrm{C} / \mathrm{P}$ values were thought to indicate eutrophic conditions because of 
the supposed eutrophic preference of Centrales, a notion refuted by the wide range of trophic preferences actually observed for centric taxa (Battarbee 1979). Stockner and Benson (1967) studied historic trends in Lake Washington and proposed the $\mathrm{A}: \mathrm{C}$ index, a ratio of the number of valves in the tribe Araphidiniae to the number of valves in the order Centrales. Centrales were assumed to be oligotrophic rather than eutrophic indicators in this scheme. Stockner (1971) later qualified the conditions under which this index would accurately indicate trophic state, but subsequent studies (e.g. Brugam 1979, Battarbee 1979, Carney 1982, Charles 1985, Whitmore 1985) have shown that the $\mathrm{A}: \mathrm{C}$ index is not a useful indicator of lake trophic status. The essential problem with these indices is that they assume ecological uniformity of diatom species over broad taxonomic groupings, whereas the individual species actually have ecologically diverse requirements (C. Reimer pers. comm.).

Schelske et al. (1983) examined concentrations of biogenic silica in sediment cores from the Great Lakes. Increases in biogenic silica were shown over time in the sediments of all of the Great Lakes because eutrophication led to a more rapid production and sequestering to sediments of diatom valves. The peak in sedimentary storage of biogenic silica in Lakes Ontario and Erie occurred in the 1800's and was followed by a decline that resulted from silica limitation (Kilham 1971) as these lakes continued to eutrophicate. Sedimentary biogenic silica increased after 1940 in Lake Michigan and reached a maximum abundance in 1964, after which it declined. Stoermer et al. (1990) used cluster analysis to delineate diatom zonation in a sediment core from Lake Michigan 
and determined that changes in diatom species composition support the eutrophication inferences of sedimentary biogenic silica. Schelske (1988) demonstrated that recent declines in sedimentary biogenic silica are consistent with historic water concentration data that showed a decline in dissolved silica in Lake Michigan.

Whitmore (in press) studied the relationship in Florida lakes between sedimentary diatom concentrations and accumulation rates and lake trophic state as indicated by a TSI based on water-column Chl $a$. Both periphyton and planktonic diatom concentrations were positively correlated with water-column $\mathrm{Chl} a$. Because diatom accumulation rates were determined by three order of magnitude differences in sedimentary diatom concentrations rather than by the small range in bulk sediment accumulation rates, sedimentary diatom concentrations were shown to be more expedient predictors of Chl $a$ than diatom accumulation rates. Sedimentary concentrations were found to be unreliable predictors of trophic state when factors such as silica limitation or blue-green bacterial inhibition limit phytoplankton production, or when post-depositional changes affect preservation of diatom valves.

Bailey and Davis (1978) used a multiple regression of diatom taxa to predict water-column total $P$ in a set of 19 lakes in Maine. The best model explained $96 \%$ of the variance of total $\mathrm{P}$ in these lakes, but contained only a few species of Fragilaria as independent variables. Such models based on a limited number of taxa may prove unreliable when applied to lakes outside of their calibration data sets because of the large number of environmental factors that can influence the distribution and abundance of species (Patrick 
1973). Predictive approaches that utilize groups of taxa are generally more reliable than those based on a limited number of taxa (Battarbee 1979).

Diatom indices have been proposed that used trophic autecological classifications of taxa for lakes in Florida (Whitmore 1985, 1989) and in Canada (Agbeti and Dickman 1989). In both of these studies, diatoms were classified into 5 autecological categories, and their percentages were structured into an index similar to indices used for $\mathrm{pH}$ reconstructions (Nygaard 1956, Renberg and Hellberg 1982). Log-transformed values of the indices were regressed with $\log$-transformed total $\mathrm{P}$ and $\mathrm{Chl} a$ in the Canadian lakes and with TSI(TP) and TSI(Chl $a$ ) in Florida lakes. Logtransformed values of the diatom inferred trophic index (D.I.T.I.) (Agbeti and Dickman 1985) explained $71 \%$ of the variance in logtransformed total $P$ in the Canadian lakes, and the TROPH 1 index (Whitmore 1989) explained $83 \%$ of the variance in TSI(TP) in Florida lakes. Agbeti and Dickman concluded that the D.I.T.I. diatom index was influenced by unspecified environmental factors. Whitmore showed that $\mathrm{pH}$ was an important covariable affecting diatom assemblages in the Florida lakes, though partial correlations demonstrated that the predictive model using the TROPH 1 diatom index was not statistically confounded by $\mathrm{pH}$. Despite the fact that silica limitation or cyanobacterial inhibition may affect paleoproductivity inferences based on diatom accumulation rates (Anderson 1990c), the TROPH 1 index still seems useful because diatom assemblages are qualitatively distinct at the high nutrient conditions where their populations are limited (Whitmore in press). 
Canfield (pers. comm.) pointed out that while diatom indices such as TROPH 1 may be accurate predictors of water-column total P, they are not comprehensive indicators of lakewide trophic state because they ignore the important component of primary production that is in macrophytes.

Anderson et al. (1990) used the reciprocal averaging (RA) indirect ordination method to study historical changes in lake trophic state in Lough Augher, Northern Ireland resulting from loading and later re-direction of nutrients from point sources. Anderson et al. did not correlate RA axes with water quality indicators to quantitatively assess trophic state changes, but instead plotted RA axes against each other to graphically depict assemblage similarity and ecological change.

Charles (1985) investigated the relationship between lake-water characteristics and sedimentary diatom assemblages in 38 Adirondack lakes. Charles used reciprocal averaging to determine which environmental variables influenced the diatom assemblages, and found that total $\mathrm{P}$ was a weak correlate with the first RA axis. He concluded that $\mathrm{pH}$ proved a more important determinant of diatom assemblage composition in the Adirondack lakes because those lakes spanned a wider range of $\mathrm{pH}$ than of trophic state.

Huttunen and Meriläinen (1986) used detrended correspondence analysis, another indirect ordination method, to interpret historical limnological trends in a Finnish lake and were able to demonstrate eutrophication following deforestation and the inception of agriculture, as well as recent lake acidification. 
Fritz (1990) used the canonical correspondence option of CANOCO (ter Braak 1987) in a constrained ordination of 127 diatom taxa in 64 lakes of the northern Great Plains. The ordination axis was constrained by the variable salinity, which resulted in a predictive model that Fritz used in reconstructing historical changes in the salinity of Devils Lake.

In recent studies of Canadian lakes (Christie and Smol 1990, Hall and Smol 1990), attempts to construct trophic predictive models have involved canonical correspondence analysis as an explanatory ordination method to identify limnological variables affecting diatom assemblages in lakes having a wide range of trophic state but a narrow range of $\mathrm{pH}$. Weighted averaging calibration (Line and Birks 1990) was then used as the regression method to construct transfer functions and determine historical changes in trophic variables. Anderson (1990c) examined the weighted averaging approach to quantitative trophic-state reconstruction and warned that weighted averaging studies largely utilize open water phytoplankton and $\mathrm{v}$ chemical data, and that they ignore littoral community production and chemistry. Anderson suggested that modeling methods should be coupled with the use of multiple cores to calculate whole-basin diatom accumulation rates that would give a reliable measure of both plankton and periphytic paleoproduction.

\section{Comments on Statistical Methods}

Cluster analysis is a statistical method that groups observations into clusters that reflect their similarity without a priori consideration of which factors are influencing the similarities. 
Cluster analysis of diatom assemblages from a set of lakes, for instance, would result in clusters of diatom species that demonstrate a similar response to the environmental variables responsible for between-lake variance in the assemblages.

Indirect ordination techniques, which include reciprocal averaging, principal components analysis and detrended correspondence analysis, reduce the number of variables (e.g. diatom taxa) by combining the variables into a series of linear combinations of the original variables called ordination axes. With indirect ordination methods, ordination axes are just particular combinations of variables that are uncorrelated and appear in the order that best explains the variance within the data set. The relationship between indirect ordination axes and environmental variables that influence the data set can then be determined by correlating axes with environmental variables. Other ordination axes, however, may be more suitable for establishing the relationship between the taxa and specific environmental variables influencing diatom assemblages.

Canonical correspondence analysis (CCA), included in canonical community ordination (CANOCO), is a direct ordination technique in which variables are combined into ordination axes that are constrained by specific environmental variables (ter Braak 1987). Ordination axes are independent and uncorrelated, and are created in order of their variance explained by the environmental variables. CANOCO, therefore, effectively inserts a regression model into the ordination model. When a single environmental variable is specified in the CCA procedure, CANOCO can be used to obtain eigenvectors to 
construct a calibration model for that environmental variable (ter Braak 1987).

Principal components analysis is a linear ordination method in which species demonstrate a linear response over the ordination axes and species coefficients, called eigenvectors, are calculated as slopes of those lines. In weighted averaging methods, which include detrended correspondence analysis (DCA), species are assumed to respond in a modal fashion over the ordination range, and coefficients are equal to the center or optimum of their distribution curve along the range of ordination values (ter Braak 1987). CANOCO is an extension of DCA that also assumes a modal species distribution over ordination axes (ter Braak 1987).

Reciprocal averaging (RA), or factor correspondence analysis, is an extension of principal components. Hill and Gauch (1980) compared RA and DCA and concluded that DCA was a better method. A main fault they cite with RA is that the second ordination axis demonstrates an 'arch effect' that is a mathematical artifact relating to no real structure in the data. Charles (1985), for instance, observed this arch effect in his study of diatom communities of Adirondack lakes and found it made ecological interpretations difficult. A second fault of RA is that it does not preserve ecological distances between species along the ordination axes (Hill and Gauch 1980). Anderson et al. (1990) have presented, on the other hand, an argument that RA is a preferred method over DCA because DCA destroys spatial relationships between successive samples that is necessary to demonstrate a time trajectory of community response in 
sediment cores, and it interferes with assessment of the importance of species on samples.

\section{Effects of Spatial Variation on Diatom Assemblages}

In paleolimnological work, there is frequently an implicit assumption that diatom assemblages have been homogenized by resuspension prior to deposition so that a single surface-sediment sample or a sediment core reflects lakewide mean limnological conditions. If spatial variability exists in species composition of diatom assemblages in surficial sediments, variance is introduced into the calibration data sets used for models describing diatom/limnological relationships. Spatial variability in diatom assemblages from sediment cores may also affect the precision of historical inferences.

Anderson (1990a) studied variability in diatom concentrations and accumulation rates in 10 sediment cores from Lough Augher and found that diatom accumulation rates and concentrations were not spatially uniform. Differences resulted partly from variance in bulk sediment accumulation rates that was not related in a predictable way to water depth (Anderson 1990b). Factors including localized resuspension, stream inputs, slumping and the effects of macrophytes on wind circulation patterns were responsible for the spatial differences in sedimentation rates. Anderson concluded that no single sediment core reflected the mean accumulation rate of the whole basin.

Studies on the spatial heterogeneity of species composition in surficial sediment samples have shown that no single sample 
represents an "average" lakewide diatom assemblage (Earle et al. 1988). Variance due to site seems to increase when habitat specificity of taxa is considered, i.e. when planktonic and periphytic taxa are separated (Dixit and Evans 1986, Anderson 1990a). Planktonic taxa typically show greater representation in deeper water, whereas periphytic taxa show relatively little redistribution and are more abundant in the littoral zone. With respect to spatial variation within a lake basin, periphyton contribute a substantial amount of the variance observed in diatom assemblages because their substrate preferences lead to patchy distributions (Earle et al. 1988). In a sediment core from any particular site in a lake, however, periphytic diatoms tend to demonstrate more even accumulation rates than do planktonic taxa (Anderson 1990a, 1990b).

Spatial variation in subfossil diatom assemblages does not seem to invalidate construction of calibration data sets using single samples from each lake when lakes are sampled over a limnological range. Earle et al. (1988) have shown that single-sample, betweenlake differences are high enough to indicate that the comparison of diatom assemblages between lakes is valid if samples are retrieved from deeper areas with gentle slopes rather than from steep-sloped areas.

Spatial variation does not preclude meaningful application of predictive models to historical samples provided that the effects of sample variance on inferences are understood. Anderson (1990a) showed that sediment cores retrieved from deeper water sites consistently demonstrated greater resolution of historical changes in 
limnology than cores taken in littoral areas. Although taxon resolution varied with sediment core site, each core from Lough Augher gave fundamentally the same record of eutrophication. Dixit and Evans (1986) concluded that when time or financial constraints are important, a sediment core from the deepest site on a lake will provide a reliable indication of historical trends in $\mathrm{pH}$. Because of differences in $\mathrm{pH}$ inferences from various sites, however, Dixit and Evans indicate that it is important to analyze several sediment cores and demonstrate replicability for absolute inferences.

\section{Purpose}

The purpose of this study is to develop methods that would permit quantitative assessment of historical macrophyte biomass in lakes using sedimentary indicators. Macrophyte standing crop has been documented to be high (Canfield et al. 1983a) in lakes such as Fairview in Orange Co., Florida that appear oligotrophic and have been used for calibration of diatom/trophic state models (Whitmore 1989). Conventional paleolimnological reconstructions of trophic state have focused on inferring water-column nutrient concentrations principally from planktonic diatom assemblages, but they have ignored the often substantial component of primary production occurring in macrophytes.

Historical inferences of lower water-column nutrient concentrations obtained with existing diatom predictive models don't necessarily indicate that lakes were formerly less productive. A negative correlation has been shown between water-column nutrient concentration or phytoplankton biomass as measured by $\mathrm{Chl} a$ and 
macrophyte biomass (Canfield et al. 1983a, Canfield et al. 1984).

Historic samples indicating low water-column nutrient concentrations may represent times of high macrophyte production, especially if the cyclic changes in water level of Florida's shallow lakes (Deevey 1988) promote a periodic lakeward expansion of macrophyte beds. If the trophic trajectory of lake ecosystems over time is to be fully understood, a more holistic consideration of historical trophic state is required, one that includes the macrophyte component of production.

Conventional sedimentary indicators of macrophytes are not appropriate for quantitative reconstructions for a variety of reasons:

1) pollen and seed production is species specific quantitatively and is often absent in plants such as Hydrilla that largely undergo vegetative reproduction. Models predicting historical macrophyte standing crop from sedimentary pollen or seeds would have to be calibrated for each individual species;

2 ) there are no known photosynthetic pigments that would be preserved in sediments and that are specific to macrophytes;

3 ) diagenesis often affects the preservation of macrophyte remains.

Diatoms are considered as potential macrophyte indicators in this study because diatoms are usually well-preserved in lake sediments and they are ecologically specific. Life-form classifications are available (Lowe 1974) that permit separate consideration of planktonic and periphytic taxa. Sedimentary concentrations and accumulation rates of periphytic taxa might be expected to demonstrate a positive correlation with the amount of submerged macrophyte biomass for 2 reasons. First, a positive relationship exists between periphytic biomass and the increased substrate area afforded by macrophytes with many small or finely-dissected leaves such as Hydrilla (Cattaneo and Kalff 1981). Secondly, evidence also 
indicates that diatom biomass might be stimulated by nutrient release from macrophyte substrates (Burkholder and Wetzel 1990). The specific objectives of this study are to:

1) obtain information on diatom assemblages in a calibration set of Florida lakes that represent a wide range of macrophyte presence;

2) identify periphyton and planktonic components of the assemblages;

3 ) perform explanatory analyses to determine which variables influence diatom assemblages over the range of macrophyte presence;

4) construct predictive models that could be used to quantitatively assess historical macrophyte standing crop using percentages, sedimentary concentrations or accumulation rates of diatoms; and

5) derive a plan to assimilate historic macrophyte inferences into a scheme that permits a more complete assessment of former lake trophic state than models restricted to concentrations of water column nutrients.

I propose to develop new multivariate models predicting historical macrophyte presence in the following manner. For explanatory analyses of diatom communities, a cluster analysis will be used to identify diatom taxa with similar ecological responses. An indirect (unconstrained) ordination method, such as PCA, will be used to ordinate taxa in linear combinations that best explain the variance between assemblages. The ordination axes will then be correlated with environmental variables to determine which variables exert the greatest influence on diatom assemblages. Multivariate predictive models will be constructed by stepwise linear regression of taxa and by the direct ordination method canonical correspondence analysis, in which the linear combinations of diatom taxa are constrained in a manner best explained by the limnological variables of interest. 


\section{CHAPTER 2}

\section{METHODS}

\section{Collection of Sediment Samples}

Sediment samples were collected from the sediment-water interface of 30 Florida lakes. Lakes chosen for study were those named in data sets (Canfield and Duarte 1988, Canfield unpub. data) that contained data on macrophyte abundance. Lakes were selected to cover the range of macrophyte presence as uniformly as possible. Sediment samples were collected in two sets of field surveys. Survey Set 1 consisted of samples from 10 lakes collected in the Spring of 1982. Samples were collected at a mid-lake station using an Ekman dredge. Volumetric portions were removed with a pipette and transferred to $125-\mathrm{ml}$ Nalgene bottles. Sediment samples in Survey Set 2 were collected between November 1987 and May 1988 from 20 additional Florida lakes. These samples were collected with a 77$\mathrm{cm}$ long, $8.8-\mathrm{cm}$ diameter acrylic piston corer that was driven into the sediment with $1 \mathrm{~m}$ long sections of magnesium-zirconium coring rods. Water above the sediment-water interface was removed by aspiration. The top $2 \mathrm{~cm}$ of sediment was collected with a syringe and transferred to $125 \mathrm{ml}$ Nalgene bottles. 


\section{Laboratory Analyses}

Sediment samples were subdivided in the Paleoecology Laboratory of the Florida Museum of Natural History for diatom analyses, estimation of bulk sediment accumulation rates by $210 \mathrm{~Pb}$ assay, and determination of percent organic matter.

Sediment samples for diatom analyses were cleaned using hydrogen peroxide and potassium dichromate (Van der Werff 1955). Digested samples were diluted with deionized water in $400-\mathrm{ml}$ beakers and settled overnight. The supernatant solutions were removed by vacuum aspiration and the process of dilution, settling and aspiration was repeated until the dichromate color was no longer visible. Cleaned samples were suspended in $60 \mathrm{ml}$ of water and settled onto coverslips in evaporation trays (Battarbee 1973). Dried coverslips were mounted on glass slides using Hyrax mounting medium.

A minimum of 500 diatom valves was counted and identified on a single slide of each sample using an American Optical Microstar microscope at $1500 \mathrm{X}$ with a dark-phase condenser. Each diatom valve was identified to the lowest taxonomic level possible using standard diatom floras including those of Patrick and Reimer (19661975) and Hustedt (1930,1930-1966).

The concentration of diatoms (D CONC) in the sediment samples was calculated with the following formula:

$\mathrm{D}-\mathrm{CONC}=\mathrm{C}(\mathrm{PVD})^{-1}$

where $\mathrm{D}-\mathrm{CONC}=$ number of frustules $\mathrm{g}^{-1}$ dry weight of sediment

$\mathrm{C}=$ number of valves counted

$\mathrm{P}=$ proportion of settling tray area counted 


$$
\begin{aligned}
& \mathrm{V}=\mathrm{cm}^{3} \text { of sediment in initial sample } \\
& \mathrm{D}=\mathrm{g} \text { dry weight of sediment } \mathrm{cm}^{-3} \text { of initial sample. }
\end{aligned}
$$

Life-form autecological information for the majority of diatom taxa was obtained from the literature (Lowe 1974, Patrick and Reimer 1966-1975, Hustedt 1930). The concentrations of periphytic valves (PERICONC) and euplanktonic valves (PLNKCONC) were calculated by multiplying the concentration of diatoms in the samples by the proportion of periphyton and euplankton in each sample. Tychoplanktonic diatoms normally show a periphytic lifeform, though are often suspended with the plankton (Lowe 1974). Tychoplanktonic taxa were arbitrarily assumed to be $1 / 3$ euplanktonic for these calculations.

Bulk-sediment accumulation rates were measured for each sediment sample using the Binford and Brenner (1986) dilution tracer method based on $210 \mathrm{~Pb}$ assay. $210 \mathrm{~Pb}$ assay for 8 lakes from Survey Set 1 was performed by a modification of the Eakins and Morrison (1978) method that involved estimating $210 \mathrm{~Pb}$ recovery of samples from the proportion of recovery onto copper planchettes of a 208Po spike. Atmospherically derived (unsupported) $210 \mathrm{~Pb}$ activity was calculated as the difference between total residual $210 \mathrm{~Pb}$ activity in the samples and an average supported $210 \mathrm{~Pb}$ activity $\left(0.80 \mathrm{pCi}^{-1}\right)$ that was estimated from sediment cores of nine other Florida lakes (Binford and Brenner 1986).

Sediment samples for $210 \mathrm{~Pb}$ assay of Survey Set 2 lakes were dried, ground with mortar and pestle and weighed. These samples were sealed in polypropylene tubes for greater than 3 weeks to permit ingrowth of ${ }^{226} \mathrm{Ra}$ daughter products. Radionuclide activity 
was then measured using an ORTEC Intrinsic Germanium Detector connected to a 4096-channel multichannel analyzer. The unsupported activity was obtained by difference between total residual $210 \mathrm{~Pb}$ activity and supported activity of each sample as assessed from ${ }^{214} \mathrm{Bi}$.

Bulk-sediment accumulation rates (SEDACCUM) were estimated for samples from lakes in both survey sets using the following formula:

SEDACCUM $=\mathrm{F}^{210} \mathrm{PbA}^{-1}$

where SEDACCUM $=\mathrm{g}$ dry sedimentcm ${ }^{-2} \mathrm{yr}^{-1}$ $\mathrm{F}^{210} \mathrm{~Pb}=$ flux of $210 \mathrm{~Pb}$ fallout $\left(\mathrm{pCi} \mathrm{cm}^{-2} \mathrm{yr}^{-1}\right)$

$\mathrm{A}=$ unsupported $210 \mathrm{~Pb}$ activity in sediment $\left(\mathrm{pCi} \mathrm{g}^{-1}\right)$. Annual diatom accumulation rates (D-ACCUM) were estimated as follows:

D-ACCUM $=(\mathrm{D}-\mathrm{CONC})($ SEDACCUM $)$

where $\mathrm{D}$-ACCUM $=$ valves $\mathrm{cm}^{-2} \mathrm{yr}^{-1}$.

The annual accumulation rates of periphytic valves (PERIACCM) and euplanktonic valves (EUPLACCM) were obtained by multiplying the periphyton and euplankton proportions of each sample by the total diatom accumulation rates.

Subsamples of $1.001 \mathrm{~cm}^{3}$ wet sediment were dried at $60{ }^{\circ} \mathrm{C}$ in a drying oven. Dry weight per unit volume (rho) was then measured for each sample by weighing the dry material on an Ainsworth $24 \mathrm{~N}$ analytical pan balance. Percent loss on ignition (\% L.O.I.), a measure of sedimentary organic matter content, was determined for each sample by weighing the sediment samples before and after 
combustion in a muffle furnace for $1 \mathrm{hr}$ at $550{ }^{\circ} \mathrm{C}$. Percent loss on ignition was then calculated as:

\% L.O.I. $=100 \times(1-$ (sample weight before combustion/sample weight after combustion)).

Organic matter accumulation rates (ORGACCUM) were calculated with the following equation:

ORGACCUM = SEDACCUM x (\% L.O.I./100)

where ORGACCUM $=\mathrm{g}$ dry organic matter $\mathrm{cm}^{-2} \mathrm{yr}^{-1}$.

\section{Quantifying Macrophyte Presence}

Researchers from the Department of Fisheries and Aquaculture at the University of Florida obtained quantitative macrophyte data for the survey lakes in field work conducted between 1982 and 1988. The percentage of the lake area covered by macrophytes (percent-area coverage) was obtained for 23 lakes by planimetry on morphometric maps. The area covered by submergent vegetation as estimated from recording fathometer transects (Canfield and Duarte 1988) was added to the area covered by emergent and floatingleaved vegetation. The percentage of the lake volume filled with macrophytes (percent-volume infestation) was also estimated morphometrically for 30 lakes using the percent areal coverage of submerged macrophytes and the height of submerged vegetation as indicated by fathometry (Maceina and Shireman 1980).

Morphometric data including lake surface area, shoreline length, shoreline development and mean depth were available for 24 of the survey lakes. 
The average wet-weight biomass per unit area of submerged, emergent and floating-leaved macrophytes was determined from $0.25 \mathrm{~m}^{2}$ quadrats randomly sampled from 10 transects through the littoral zones of 23 lakes. Above-ground biomass in each quadrat was collected by divers, spun to remove excess water and weighed to the nearest $0.1 \mathrm{~kg}$ (Canfield and Duarte 1988).

\section{Water Chemistry Data}

Median water chemistry values for the lakes in Survey Set 1 were obtained from the Florida Lakes Data Base of the Water Resources Research Center at the University of Florida. Water quality variables selected from this data set included median values for total $\mathrm{P}$, total $\mathrm{N}, \mathrm{Chl} a$, Secchi depth, specific conductance and $\mathrm{pH}$.

Mean water chemistry values were obtained by the Department of Fisheries and Aquaculture for each lake in Survey Set 2 by averaging data from 3 mid-lake stations (M. Hoyer, pers. comm.). Total $\mathrm{P}$ analyses were performed following persulfate digestion (Murphy and Riley 1962, Menzel and Corwin 1965), and total $\mathrm{N}$ was measured using a modified Kjeldahl technique (Nelson and Sommers 1975). Water samples were filtered through a Gelman type A-E glass fiber filter and Chl $a$ was measured using the Yentsch and Menzel (1963) method and Parson and Strickland (1963) equations. Secchi depth was measured with a $20-\mathrm{cm}$ black and white Secchi disk. Trophic state index (TSI) values (Huber et al. 1982) were calculated using the mean or median values of total P, total $\mathrm{N}, \mathrm{Chl} a$ and Secchi depth for each lake in Survey Sets 1 and 2. Specific conductance was measured with a Yellow Springs Instrument Company model 31 
conductivity bridge. $\mathrm{pH}$ was measured with an Orion $601 \mathrm{~A} \mathrm{pH}$ meter.

\section{Statistical Analyses}

Data for diatom, macrophyte and water chemisty variables were stored as Statistical Analysis System (SAS Inst., Inc. 1985) data sets using the University of Florida's Northeast Regional Data Center. I plotted the percent-area coverage, percent-volume infestation, and submerged, emergent and floating-leaved biomass for macrophytes against the percentage, concentration and accumulation rates of diatom species to identify taxa responding to macrophyte presence. Pearson product-moment correlation coefficients were obtained between percent loss on ignition, organic-matter accumulation rates and macrophyte variables using the SAS CORR procedure (SAS Inst., Inc. 1985). I also obtained correlation coefficients between macrophyte variables and the percentages, concentrations and accumulation rates of planktonic and periphytic diatoms. Correlation coefficients were calculated between the macrophyte variables and log-transformed concentrations and accumulation rates of diatoms. In order to determine whether morphometric and chemical variables have covariable effects on diatom-macrophyte relationships, I obtained correlation coefficients between macrophyte, morphometric and water chemistry variables.

For purposes of multivariate statistical analyses, it was essential to reduce the number of diatom species from the 223 diatom taxa observed. I examined plots of diatom percentages versus percentarea coverage and percent-volume infestation, and selected fortyseven taxonomic groups, several of which were the sum of taxa in 
the same genus. Because of the large number of rare taxa present, this preserved most of the diatom information in each sample (mean $=96.6 \%$ ) while substantially reducing the number of species.

Hierarchical cluster analysis was performed on the 47 taxonomic groups using the SAS VARCLUS procedure (SAS Inst., Inc. 1985). I applied this procedure to the percentages, concentrations and accumulation rates of the taxonomic groups, and repeated the procedures after partialling out the effects of TSI(AVG) and $\mathrm{pH}$. Tree diagrams of the hierarchical clusters from each analysis were constructed using the SAS TREE procedure (SAS Inst., Inc. 1985). Scores for diatom clusters were obtained for each lake in the survey using standardized scoring coefficients from the cluster analyses and the SAS SCORE procedure (SAS Inst., Inc. 1985). I then correlated the scores for each cluster with macrophyte, chemical and morphometric variables using the SAS CORR procedure to determine which variables most influenced each cluster of taxa.

Principal components analyses of the percentages, concentrations and accumulation rates of the 47 diatom taxonomic groups were performed using the SAS PRINCOMP procedure (SAS Inst., Inc. 1985). I repeated the PRINCOMP procedure for each of the three models while partialling out the effects of TSI(AVG) and $\mathrm{pH}$. The standardized principal component scores of the first 8 principal components in each test were calculated for the diatom assemblages in the survey lakes using the SAS SCORE procedure. I then correlated the principal component scores with macrophyte, water chemistry and morphometric variables to identify the environmental variables influencing each principal component. 
Canonical correspondence analysis (CCA) was performed on the percentage data for 47 diatom taxonomic groups using the canonical community ordination (CANOCO) statistical package developed by ter Braak (1987). In the first set of computations, the diatom groups were ordinated in an axis constrained by the environmental variable percent-volume infestation. In a second set of computations, 47 diatom taxa were ordinated into an axis constrained by percent-area coverage.

Multivariate models that predict percent-volume infestation, percent-area coverage and biomass for submerged, emergent and floating-leaved plants were derived using the maximum $\mathrm{R}^{2}$ improvement method of the SAS STEPWISE procedure (SAS Inst., Inc. 1985). I reduced the number of independent diatom variables in each stepwise regression to 20 or less, a recommended maximum for this procedure (SAS Inst., Inc. 1985), after examining plots of diatom taxonomic groups versus macrophyte variables. Regressions were performed for each macrophyte variable using percentage data for the diatom groups. The regressions for percent-area coverage and percent-volume infestation were repeated using concentration and accumulation rate data for the diatom groups.

I selected the best model in each STEPWISE regression procedure by plotting Mallows' $\mathrm{Cp}$ statistic versus the number of variables in each model (p) and selecting the model in which $\mathrm{Cp}$ was approximately equal to $\mathrm{p}$ (Daniel and Wood 1971). Adjusted $\mathrm{R}^{2} \mathrm{~s}$, which show the coefficient of determination after removing the inflating effect of dependent variables, were calculated using the SAS RSQUARE procedure (SAS Inst., Inc. 1985). 
Partial correlations (Ott 1977) were used to determine if predictive models were statistically free from confounding effects of environmental variables correlated with their dependent variables. I accomplished this by calculating multiple correlation coefficients as the square root of the coefficients of determination for the multivariate models. The multivariate models were then regressed with the covariant dependent variables using the SAS GLM procedure (SAS Inst., Inc. 1985), and I calculated multiple correlation coefficients for these confounded forms of the model. Partial correlation coefficients were calculated using the multiple correlation coefficients to assess whether models with correct dependent variables were significant when the effects of the covariables were held constant.

Diatom-index values (TROPH 1) (Whitmore 1989) were calculated for the subfossil diatom assemblages in the survey lakes. A predictive model was developed to yield water-column total $\mathrm{P}$ estimates from subfossil diatom assemblages for historic WCP (Canfield et al. 1983a) inferences. The 51 lakes used to construct this model were the lakes included in the present study, lakes in Whitmore's (1989) study, and Lake Francis in Highlands County. Water-column total $\mathrm{P}$ values for the lakes outside of the present study were median values obtained from the Florida Lakes Data Base. TROPH 1 values for subfossil diatom assemblages were regressed with water-column total $P$ values using the SAS GLM procedure (SAS Inst., Inc. 1985).

Because of the significant negative correlation between macrophyte presence and water-column nutrient concentrations 
(Canfield et al. 1984), it was important to assess whether macrophyte presence would have a significant confounding effect on the model for predicting water-column total P. Log-transformed TROPH 1 index values were correlated with log-transformed total $\mathbf{P}$ and percentarea coverage values for the survey lakes. 


\section{CHAPTER 3}

\section{RESULTS}

Thirty lakes were sampled in the surface-sediment survey (Table 1). Lake Miona was removed from the data set prior to statistical analyses because the lake was observed to contain virtually no macrophytes despite a percent-volume infestation value of $86 \%$ measured by Canfield (unpub. data). Triploid grass carp had been introduced to Lake Miona by the Florida Game and Freshwater Fish Commission in the time between the macrophyte and surfacesediment surveys in order to control aquatic vegetation (M. Hoyer, pers. comm.).

Many correlation coefficients were used in this study to assess relationships between morphometric, water-chemistry and macrophyte variables and to determine which environmental variables influenced specific groups of diatoms. The criterion for significance of all correlation coefficients discussed below is the $\alpha=$ 0.05 level of significance.

Water-chemistry values (Table 2a) showed that survey lakes ranged from ultraoligotrophic to hypereutrophic (TSI(AVG): 4.1 to 88.5) as determined by water-column nutrient concentrations, and from acidic to alkaline conditions ( $\mathrm{pH}$ : 4.61 to 9.03 ). Total $\mathrm{N} /$ total $\mathrm{P}$ ratios suggested that Lakes Wauberg and Alligator were $\mathrm{N}$-limited (Huber et al. 1982). Log-transformed water-column total $\mathrm{P}$ was 
Table 1. Lake, county and sampling dates for macrophyte and diatom surveys.

\begin{tabular}{|c|c|c|c|}
\hline Lake & County & $\begin{array}{l}\text { Macrophyte } \\
\text { date }\end{array}$ & $\begin{array}{l}\text { Diatom } \\
\text { date }\end{array}$ \\
\hline Alligator & Columbia & 2 Jun 1987 & $19 \operatorname{Dec} 1988$ \\
\hline Apopka & Orange & Sep 1981 & $27 \mathrm{Jul} 1982$ \\
\hline Bonny & Polk & 22 Sep 1987 & 17 Dec 1988 \\
\hline Carr & Leon & 7 Jul 1987 & 15 Jan 1989 \\
\hline Catherine & Marion & 8 Sep 1987 & 8 Dec 1988 \\
\hline Clay & Lake & 15 Jul 1986 & 20 Jan 1989 \\
\hline Crooked & Lake & 9 Jun 1987 & 17 May 1989 \\
\hline Deep & Putnam & 16 Jun 1987 & 1 Feb 1989 \\
\hline Fairview & Orange & Oct 1982 & $28 \mathrm{Jul} 1982$ \\
\hline Harris & Lake & 12 Oct 1987 & 25 Mar 1989 \\
\hline Hartridge & Polk & 11 Aug 1987 & 17 Dec 1989 \\
\hline Keys Pond & Putnam & 9 Jun 1986 & 2 Feb 1989 \\
\hline Lindsey & Hernando & 10 May 1988 & 16 Nov 1988 \\
\hline Live Oak & Osceola & 24 May 1988 & $12 \quad$ Jan 1989 \\
\hline Lochloosa & Alachua & 22 Aug 1988 & 9 Nov 1988 \\
\hline Loften Ponds & Leon & 16 May 1988 & 14 Jan 1989 \\
\hline Miona & Sumter & 19 Aug 1986 & 6 Jan 1989 \\
\hline Moore & Leon & 18 May 1988 & 15 Jan 1989 \\
\hline Mystic & Madison & Jul 1982 & 4 May 1982 \\
\hline Ocean Pond & Baker & Aug 1982 & 3 May 1982 \\
\hline Okahumpka & Sumter & Aug 1981 & 26 May 1982 \\
\hline Orange & Alachua & Oct 1982 & 15 Aug 1982 \\
\hline Patrick & Polk & 21 Jun 1988 & $18 \operatorname{Dec} 1988$ \\
\hline Rowell & Bradford & 9 Aug 1988 & 5 Dec 1988 \\
\hline Stella & Putnam & Sep 1981 & 10 Aug 1982 \\
\hline Tomohawk & Marion & 18 Jul 1988 & 8 Dec 1988 \\
\hline Townsend & Lafayette & Jul 1981 & 4 May 1982 \\
\hline Watertown & Columbia & Aug 1982 & 3 May 1982 \\
\hline Wauberg & Alachua & 22 Jul 1986 & 7 Nov 1988 \\
\hline Wildcat & Lake & Aug 1982 & 3 Aug 1982 \\
\hline
\end{tabular}


Table 2a. Summary water chemistry data for survey lakes. Sources of data were Canfield (unpub. data) and Florida Lakes Data Base.

\begin{tabular}{|c|c|c|c|c|c|}
\hline Lake & $\begin{array}{c}\text { Water-column } \\
\text { total } P \\
\left(\mathrm{mg} \mathrm{l}^{-1}\right)\end{array}$ & TSI(AVG) & TN/TP & $\mathrm{pH}$ & $\begin{array}{c}\text { Specific } \\
\text { conductance } \\
(\mu \mathrm{S} / \mathrm{cm})\end{array}$ \\
\hline Alligator & 0.320 & 74.9 & 7.4 & 7.9 & 144.0 \\
\hline Apopka & 0.192 & 88.5 & 21.0 & 8.0 & 395.0 \\
\hline Bonny & 0.050 & 71.2 & 37.2 & 7.7 & 255.8 \\
\hline Carr & 0.015 & 42.4 & 58.0 & 6.3 & 25.3 \\
\hline Catherine & 0.003 & 16.6 & 100.0 & 4.7 & 48.3 \\
\hline Clay & 0.001 & 7.4 & 360.0 & 4.8 & 52.0 \\
\hline Crooked & 0.007 & 24.3 & 47.1 & 4.6 & 44.3 \\
\hline Deep & 0.002 & 4.1 & 80.0 & 4.6 & 37.0 \\
\hline Fairview & 0.015 & 27.4 & 33.3 & 8.1 & 198.8 \\
\hline Harris & 0.028 & 66.4 & 55.4 & 8.5 & 247.7 \\
\hline Hartridge & 0.010 & 33.6 & 48.0 & 7.8 & 219.3 \\
\hline Keys Pond & 0.002 & 6.7 & 85.0 & 5.4 & 42.7 \\
\hline Lindsey & 0.017 & 41.2 & 38.2 & 6.8 & 34.0 \\
\hline Live Oak & 0.014 & 35.3 & 25.0 & 7.0 & 131.0 \\
\hline Lochloosa & 0.032 & 61.0 & 32.8 & 7.7 & 87.7 \\
\hline Loften Ponds & 0.004 & 20.5 & 97.5 & 4.8 & 19.0 \\
\hline Moore & 0.005 & 19.7 & 70.0 & 5.8 & 16.3 \\
\hline Mystic & 0.015 & 25.7 & 34.7 & 6.7 & 28.0 \\
\hline Ocean Pond & 0.040 & 46.0 & 10.5 & 5.0 & 45.5 \\
\hline Okahumpka & 0.020 & 47.2 & 47.5 & 9.0 & 201.7 \\
\hline Orange & 0.040 & 59.4 & 27.8 & 7.2 & 82.5 \\
\hline Patrick & 0.010 & 35.5 & 147.0 & 8.1 & 320.3 \\
\hline Rowell & 0.069 & 66.0 & 11.7 & 7.7 & 289.7 \\
\hline Stella & 0.010 & 25.1 & 43.0 & 7.1 & 240.0 \\
\hline Tomohawk & 0.004 & 15.7 & 52.5 & 4.9 & 34.7 \\
\hline Townsend & 0.009 & 29.5 & 64.4 & 5.2 & 23.4 \\
\hline Watertown & 0.062 & 51.7 & 16.9 & 7.4 & 153.3 \\
\hline Wauberg & 0.158 & 77.1 & 9.9 & 7.4 & 80.0 \\
\hline Wildcat & 0.008 & 20.9 & 23.9 & 4.8 & 33.0 \\
\hline
\end{tabular}


Table 2b. Summary data for macrophyte variables of survey lakes. Source of data was Canfield (unpub. data).

Lake

Percent Percent Floating Submerged Emergent area volume -leaved biomass biomass coverage infestation biomass $\left(\mathrm{kg} \mathrm{m}^{-2}\right) \quad\left(\mathrm{kg} \mathrm{m}^{-2}\right) \quad\left(\mathrm{kg} \mathrm{m}^{-2}\right)$

$\begin{array}{lrrrrr}\text { Alligator } & 10 & 10 & 1.2 & 0.0 & 1.7 \\ \text { Apopka } & 3 & 0 & 1.1 & 0.0 & 2.5 \\ \text { Bonny } & 10 & 7 & 0.0 & 3.0 & 8.1 \\ \text { Carr } & 100 & 100 & 7.0 & 9.9 & 12.7 \\ \text { Catherine } & 48 & 9 & 1.1 & 2.9 & 4.6 \\ \text { Clay } & 100 & 76 & 4.5 & 6.8 & 8.1 \\ \text { Crooked } & 27 & 2 & 3.8 & 2.4 & 26.8 \\ \text { Deep } & 97 & 21 & 2.5 & 11.7 & 10.6 \\ \text { Fairview } & & 33 & & & \\ \text { Harris } & 27 & 2 & 0.8 & 0.9 & 2.4 \\ \text { Hartridge } & 60 & 11 & 0.0 & 8.0 & 4.9 \\ \text { Keys Pond } & 40 & 8 & 0.0 & 1.0 & 2.8 \\ \text { Lindsey } & 100 & 80 & 1.3 & 1.8 & 3.0 \\ \text { Live Oak } & 100 & 55 & 0.3 & 1.6 & 2.0 \\ \text { Lochloosa } & 83 & 57 & 0.6 & 2.6 & 2.2 \\ \text { Loften Ponds } & 87 & 22 & 0.6 & 0.7 & 0.3 \\ \text { Moore } & 40 & 14 & 0.2 & 1.3 & 1.7 \\ \text { Mystic } & & 78 & & & \\ \text { Ocean Pond } & & 0 & & & \\ \text { Okahumpka } & 100 & 95 & 8.8 & 16.6 & 11.9 \\ \text { Orange } & & 79 & & & \\ \text { Patrick } & 93 & 42 & 0.4 & 1.3 & 1.1 \\ \text { Rowell } & 43 & 10 & 0.3 & 0.0 & 0.4 \\ \text { Stella } & & 39 & & & \\ \text { Tomohawk } & 43 & 12 & 0.5 & 1.0 & 1.4 \\ \text { Townsend } & & 65 & & & \\ \text { Watertown } & 7 & 1 & 0.0 & 0.0 & 1.0 \\ \text { Wauberg } & 0 & 1 & 11.2 & 4.4 & 12.1 \\ \text { Wildcat } & & 2 & & & \end{array}$


Table 2c. Summary morphometric data for survey lakes. Sources of data were Canfield (unpub. data) and Florida Lakes Data Base.

\begin{tabular}{|c|c|c|c|c|}
\hline Lake & $\begin{array}{l}\text { Mean } \\
\text { depth }\end{array}$ & $\begin{array}{r}\text { Lake } \\
\text { area }\end{array}$ & $\begin{array}{c}\text { Shoreline } \\
\text { length }\end{array}$ & $\begin{array}{c}\text { Shoreline } \\
\text { develop- } \\
\text { ment }\end{array}$ \\
\hline Alligator & 1.1 & 137 & 5.3 & 1.3 \\
\hline Apopka & 1.6 & 12412 & 54.9 & 1.4 \\
\hline Bonny & 2.0 & 143 & 6.4 & 1.5 \\
\hline Carr & 1.9 & 254 & 5.1 & \\
\hline Catherine & 3.2 & 41 & 4.5 & 2.0 \\
\hline Clay & 2.3 & 5 & 0.9 & 1.2 \\
\hline Crooked & 2.3 & 8 & 2.0 & 2.0 \\
\hline Deep & 3.0 & 4 & 1.6 & 2.3 \\
\hline Fairview & & 163 & & \\
\hline Harris & 4.0 & 5580 & 61.3 & 2.3 \\
\hline Hartridge & 3.4 & 176 & 5.5 & 1.2 \\
\hline Keys Pond & 2.9 & 5 & 1.0 & 1.3 \\
\hline Lindsey & 2.2 & 55 & 3.2 & 1.2 \\
\hline Live Oak & 3.0 & 152 & 5.0 & 1.1 \\
\hline Lochloosa & 1.8 & 2309 & 22.6 & 1.3 \\
\hline Loften Ponds & 2.6 & 5 & 2.0 & 2.6 \\
\hline Moore & 2.9 & 28 & 1.8 & \\
\hline Mystic & & 19 & & \\
\hline Ocean Pond & & 722 & & \\
\hline Okahumpka & & 394 & & \\
\hline Orange & 1.8 & 5142 & & \\
\hline Patrick & 1.8 & 159 & 4.65 & 1.04 \\
\hline Rowell & 1.3 & 147 & 5.18 & 1.21 \\
\hline \multicolumn{5}{|l|}{ Stella } \\
\hline Tomohawk & 4.4 & 15 & 4.01 & 2.92 \\
\hline Townsend & 1.5 & 44 & 3.58 & 1.52 \\
\hline Watertown & 3.8 & 19 & 1.64 & 1.06 \\
\hline Wauberg & 3.6 & 100 & 8.35 & 2.36 \\
\hline Wildcat & & 94 & & \\
\hline
\end{tabular}


found to be highly correlated with specific conductance and $\mathrm{pH}$ (Table 3, Fig. 1). Macrophyte variables were not significantly correlated with water chemistry or morphometric variables, except for percent-area coverage, that had a significant negative correlation with TSI(AVG) (Fig. 2) and log-transformed total P (Table 3).

Two hundred twenty-three diatom taxa were found in the recent sediments of the survey lakes (Appendix 1). Initially, 125 taxa had life-form preferences described in the literature (Lowe 1974, Patrick and Reimer 1966-1975), but the average percentage of valves with unknown life-form preference was $15.04 \%$. Life-form preferences were assumed for 28 additional taxa (Appendix 1) based on valve morphology. Taxa with a raphe that belonged to genera known to be largely periphytic were assumed to have a periphytic life-form preference. Two small species of Cyclotella and the long, lineate Nitzschia romana and Synedra filiformis var. exilis were assumed to be tychoplanktonic. These assumptions were discussed with Rex L. Lowe (pers. comm.), who believed them to be correct. The new lifeform assignments reduced the mean percentage of valves with unknown life-form preference in survey samples to $2.03 \%$.

TSI(AVG) and $\mathrm{pH}$ were negatively correlated with the proportion of periphytic diatoms (Fig. 3) and positively correlated with the proportion of planktonic diatoms (Fig. 4) in surficial samples (Table 4). Diatom concentrations and accumulation rates were found to vary as much as 4 orders of magnitude within the study lakes. Logtransformed accumulation rates produced more significant correlation coefficients with environmental variables than 
Table 3. Pearson product-moment correlation coefficients between water quality and macrophyte variables for survey lakes. $*=p<0.05$.

correlation coefficient

prob. $>1 \mathrm{r} l$ under Ho: rho $=0$

sample size

\begin{tabular}{lrrrr}
\hline & \multicolumn{1}{c}{$\log 10$} & TSI(AVG) & $\mathrm{pH}$ & $\begin{array}{c}\text { Specific } \\
\text { conductance }\end{array}$ \\
& total P & & & -0.298 \\
Percent & $*-558$ & $*-0.518$ & -0.185 & 0.177 \\
area & 0.007 & 0.014 & 0.410 & 22 \\
coverage & 22 & 22 & 22 & \\
& & & & -0.212 \\
Percent & -0.169 & -0.131 & 0.136 & 29 \\
volume & 0.380 & 0.497 & 0.482 & 0.269 \\
infestation & 29 & 29 & 29 & \\
& & & & -0.194 \\
Floating- & 0.124 & 0.134 & 0.072 & 0.388 \\
leaved & 0.582 & 0.552 & 0.750 & 22 \\
biomass & 22 & 22 & 22 & \\
Submerged & -0.252 & -0.219 & 0.033 & -0.136 \\
biomass & 0.258 & 0.327 & 0.883 & 0.546 \\
& 22 & 22 & 22 & 22 \\
Emergent & -0.124 & -0.121 & -0.253 & -0.251 \\
biomass & 0.582 & 0.592 & 0.256 & 0.260 \\
& 22 & 22 & 22 & \\
pH & & & & $* 0.755$ \\
& $* 0.679$ & $* 0.713$ & & $<0.001$ \\
Specific & $* 0.493$ & $* 0.569$ & & 29 \\
conductance & 0.007 & 0.001 & -- & -- \\
& 29 & 29 & &
\end{tabular}


Table 3 cont'd.

\section{correlation coefficient}

prob. > l r l under Ho: rho $=0$

sample size

\begin{tabular}{|c|c|c|c|c|}
\hline & $\begin{array}{l}\text { Lake } \\
\text { surface }\end{array}$ & $\begin{array}{l}\text { Mean } \\
\text { depth }\end{array}$ & $\begin{array}{l}\text { Shoreline } \\
\text { length }\end{array}$ & $\begin{array}{l}\text { Shoreline } \\
\text { develop. }\end{array}$ \\
\hline $\begin{array}{l}\text { Percent } \\
\text { area } \\
\text { coverage }\end{array}$ & $\begin{array}{r}-0.322 \\
0.145 \\
22\end{array}$ & $\begin{array}{r}-0.137 \\
0.553 \\
21\end{array}$ & $\begin{array}{r}-0.314 \\
0.165 \\
21\end{array}$ & $\begin{array}{r}-0.173 \\
0.452 \\
21\end{array}$ \\
\hline $\begin{array}{l}\text { Percent } \\
\text { volume } \\
\text { infestation }\end{array}$ & $\begin{array}{r}-0.106 \\
0.593 \\
28\end{array}$ & $\begin{array}{r}-0.396 \\
0.062 \\
23\end{array}$ & $\begin{array}{r}-0.230 \\
0.304 \\
22\end{array}$ & $\begin{array}{r}-0.401 \\
0.064 \\
22\end{array}$ \\
\hline $\begin{array}{l}\text { Floating- } \\
\text { leaved } \\
\text { biomass }\end{array}$ & $\begin{array}{r}-0.11 \\
0.626 \\
22\end{array}$ & $\begin{array}{r}0.043 \\
0.852 \\
21\end{array}$ & $\begin{array}{r}-0.084 \\
0.717 \\
21\end{array}$ & $\begin{array}{r}0.184 \\
0.426 \\
21\end{array}$ \\
\hline $\begin{array}{l}\text { Submerged } \\
\text { biomass }\end{array}$ & $\begin{array}{r}-0.2107 \\
0.347 \\
22\end{array}$ & $\begin{array}{r}0.0739 \\
0.750 \\
21\end{array}$ & $\begin{array}{r}-0.238 \\
0.299 \\
21\end{array}$ & $\begin{array}{r}-0.007 \\
0.976 \\
21\end{array}$ \\
\hline $\begin{array}{l}\text { Emergent } \\
\text { biomass }\end{array}$ & $\begin{array}{r}-0.165 \\
0.462 \\
22\end{array}$ & $\begin{array}{r}-0.035 \\
0.880 \\
21\end{array}$ & $\begin{array}{r}-0.175 \\
0.449 \\
21\end{array}$ & $\begin{array}{r}0.168 \\
0.467 \\
21\end{array}$ \\
\hline $\mathrm{pH}$ & $\begin{array}{r}0.343 \\
0.074 \\
28\end{array}$ & $\begin{array}{r}-0.196 \\
0.371 \\
23\end{array}$ & $\begin{array}{r}* 0.508 \\
0.016 \\
22\end{array}$ & $\begin{array}{r}-0.370 \\
0.090 \\
22\end{array}$ \\
\hline $\begin{array}{l}\text { Specific } \\
\text { conductance }\end{array}$ & $\begin{array}{r}* 0.51 \\
0.005 \\
28\end{array}$ & $\begin{array}{r}-0.216 \\
0.322 \\
23\end{array}$ & $\begin{array}{r}* 0.563 \\
0.006 \\
22\end{array}$ & $\begin{array}{r}-0.241 \\
0.281 \\
22\end{array}$ \\
\hline
\end{tabular}




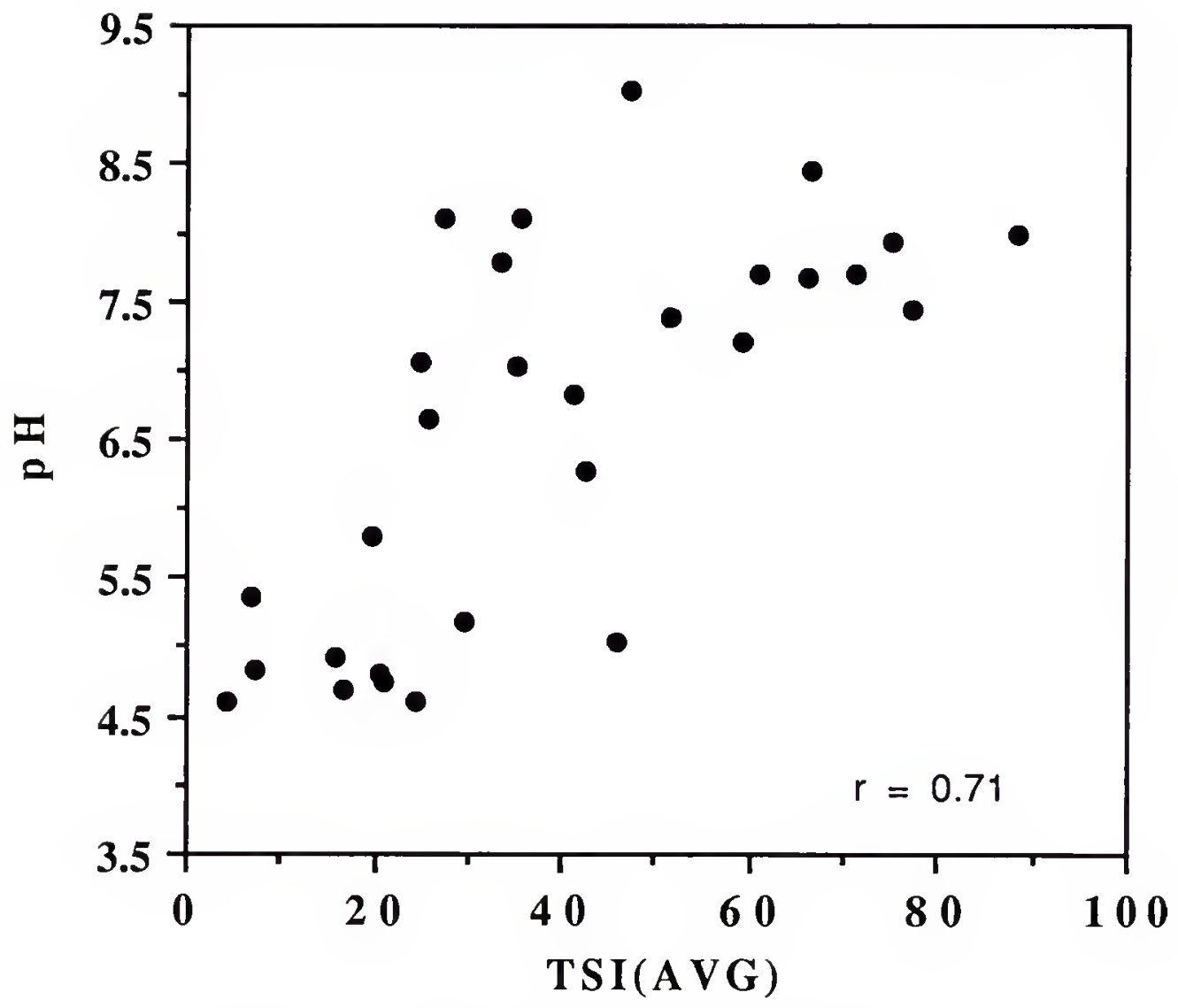

Figure 1. Plot of $\mathrm{pH}$ versus TSI(AVG) for 29 lakes in synoptic survey. 


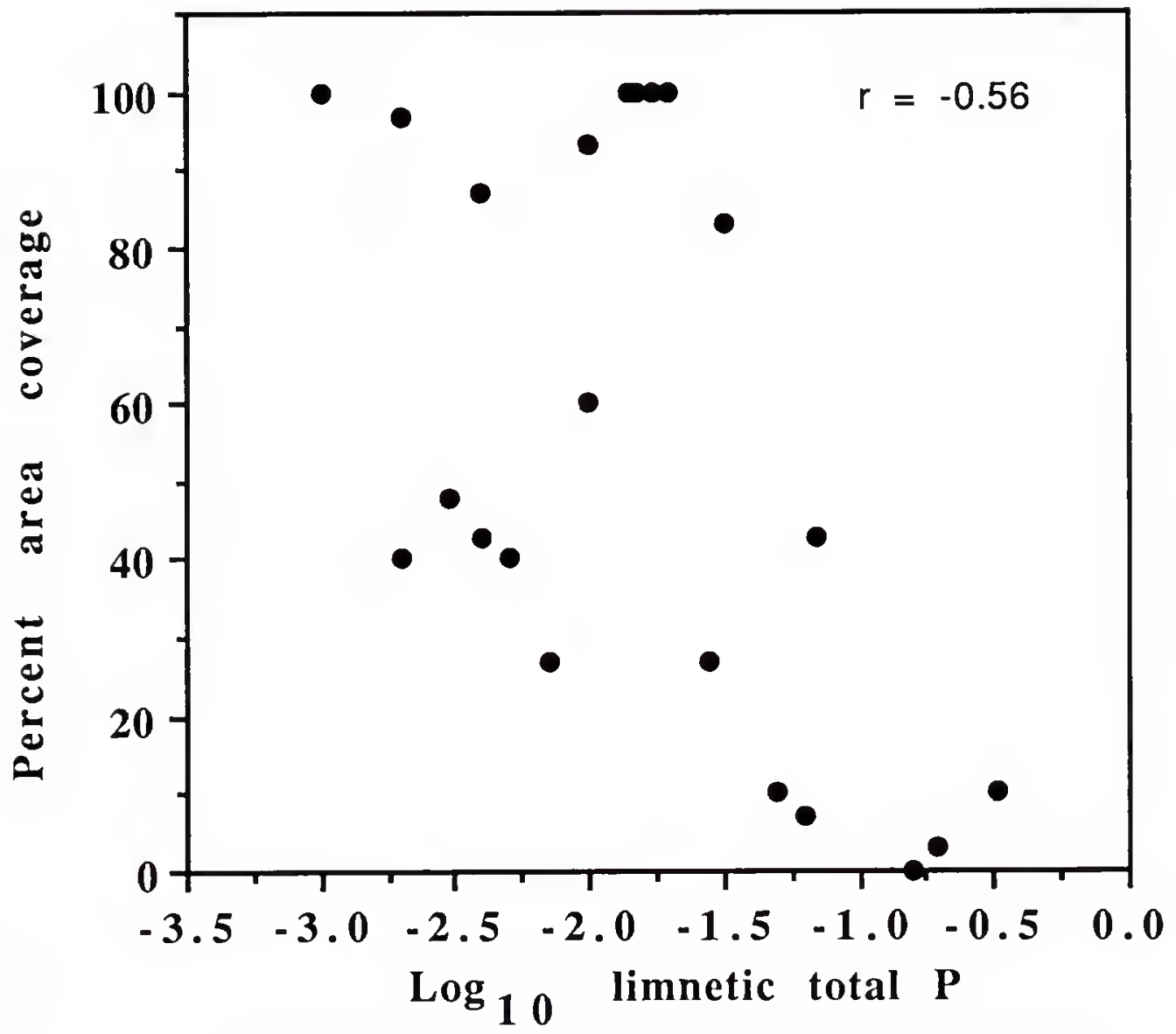

Figure 2. Plot of percent area coverage versus log-transformed limnetic total $\mathrm{P}$ for 29 survey lakes. 


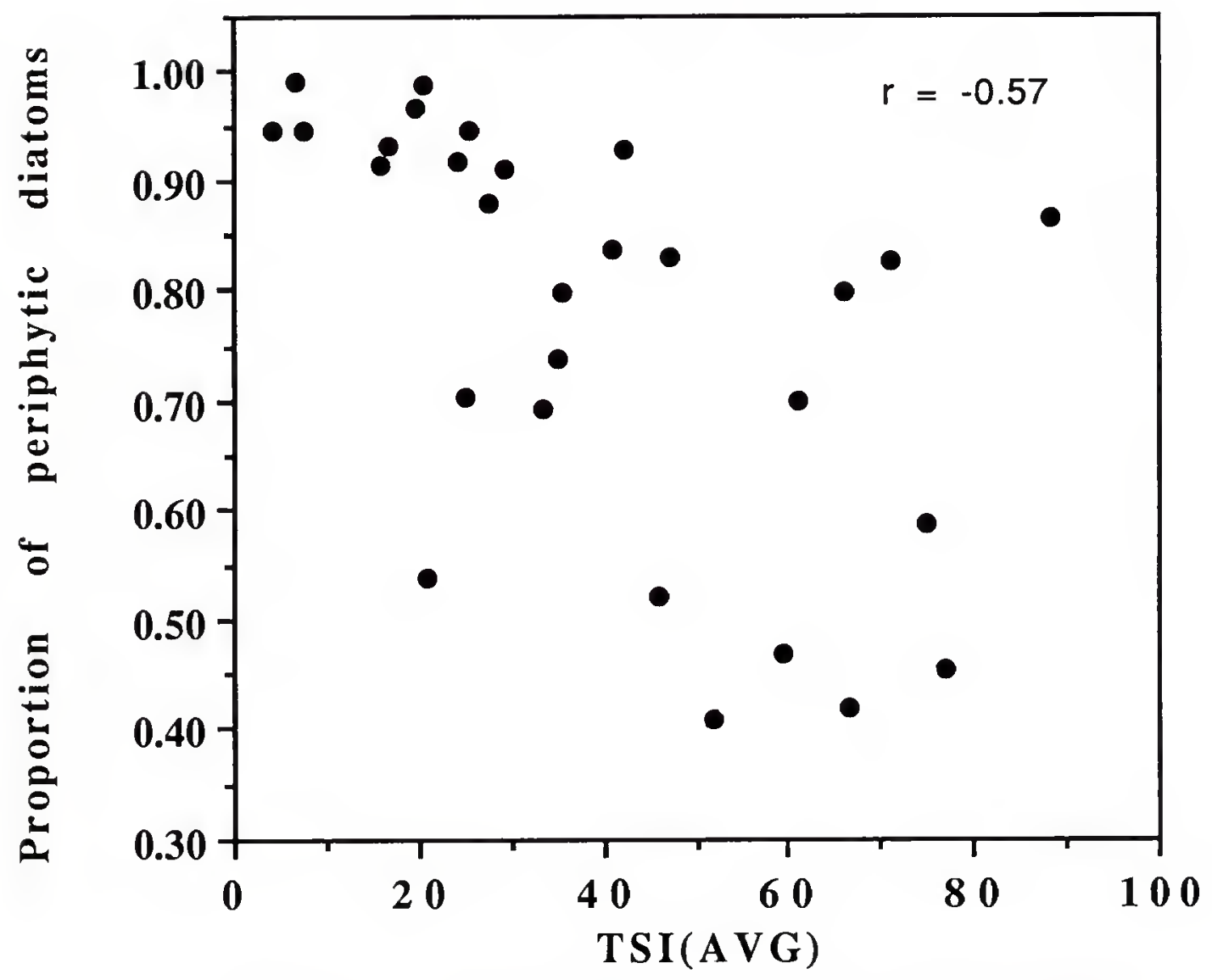

Figure 3. Proportion of diatom assemblage that periphyton represent versus TSI(AVG) for 29 lakes in survey. 


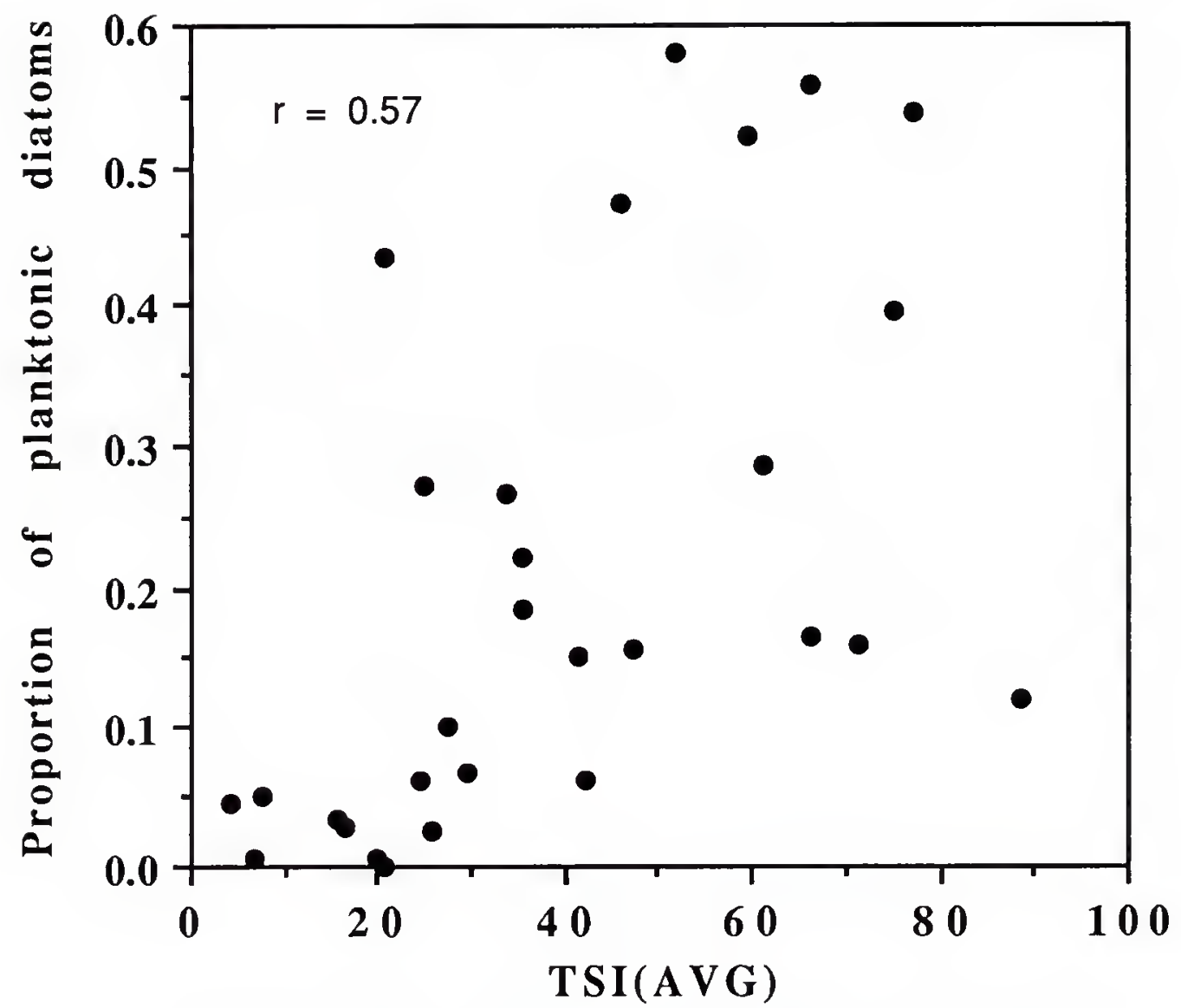

Figure 4. Proportion of diatom assemblage that plankton represent versus TSI(AVG) for 29 lakes in survey. 
Table 4. Correlation coefficients for diatom variables, which are based on proportions, sedimentary concentrations and annual accumulation rates of periphyton and plankton, with water quality, macrophyte and morphometric variables. Keys Pond was removed from periphyton concentration data because of an anomalously high diatom concentration value (see Fig. 5). $\quad *=p<0.05$.

\begin{tabular}{|c|c|c|c|c|c|c|}
\hline \multicolumn{7}{|c|}{$\begin{array}{l}\text { correlation coefficient } \\
\text { prob. }>1 \text { r } 1 \text { under Ho: rho }=0 \\
\text { sample size }\end{array}$} \\
\hline & $\begin{array}{l}\text { PERI- } \\
\text { PROP }\end{array}$ & $\begin{array}{l}\text { PLNK- } \\
\text { PROP }\end{array}$ & $\begin{array}{l}\text { PERI- } \\
\text { CONC }\end{array}$ & $\begin{array}{l}\log \\
\text { PLNK- } \\
\text { CONC }\end{array}$ & $\begin{array}{c}\log \\
\text { PERI- } \\
\text { ACCM }\end{array}$ & $\begin{array}{l}\log \\
\text { PLNK- } \\
\text { ACCM }\end{array}$ \\
\hline $\begin{array}{l}\log _{10} \\
\text { total P }\end{array}$ & $\begin{array}{r}*-0.610 \\
<0.001 \\
29\end{array}$ & $\begin{array}{r}* 0.613 \\
<0.001 \\
29\end{array}$ & $\begin{array}{r}* 0.410 \\
0.030 \\
28\end{array}$ & $\begin{array}{r}* 0.644 \\
<0.001 \\
29\end{array}$ & $\begin{array}{r}0.377 \\
0.053 \\
27\end{array}$ & $\begin{array}{r}* 0.630 \\
<0.001 \\
27\end{array}$ \\
\hline TSI(AVG) & $\begin{array}{r}*-0.566 \\
0.001 \\
29\end{array}$ & $\begin{array}{r}* 0.573 \\
0.001 \\
29\end{array}$ & $\begin{array}{r}* 0.507 \\
0.006 \\
28\end{array}$ & $\begin{array}{r}* 0.656 \\
<0.001 \\
29\end{array}$ & $\begin{array}{r}0.347 \\
0.076 \\
27\end{array}$ & $\begin{array}{r}* 0.578 \\
0.002 \\
27\end{array}$ \\
\hline $\mathrm{pH}$ & $\begin{array}{r}*-0.404 \\
0.030 \\
29\end{array}$ & $\begin{array}{r}* 0.402 \\
0.031 \\
29\end{array}$ & $\begin{array}{r}0.309 \\
0.109 \\
28\end{array}$ & $\begin{array}{r}* 0.492 \\
0.007 \\
29\end{array}$ & $\begin{array}{r}0.300 \\
0.130 \\
27\end{array}$ & $\begin{array}{r}* 0.517 \\
0.006 \\
27\end{array}$ \\
\hline $\begin{array}{l}\text { Specific } \\
\text { conductance }\end{array}$ & $\begin{array}{r}-0.223 \\
0.244 \\
29\end{array}$ & $\begin{array}{r}0.215 \\
0.262 \\
29\end{array}$ & $\begin{array}{r}0.204 \\
0.298 \\
28\end{array}$ & $\begin{array}{r}* 0.387 \\
0.038 \\
29\end{array}$ & $\begin{array}{r}* 0.392 \\
0.041 \\
27\end{array}$ & $\begin{array}{r}* 0.480 \\
0.011 \\
27\end{array}$ \\
\hline $\begin{array}{l}\text { Percent- } \\
\text { area } \\
\text { coverage }\end{array}$ & $\begin{array}{r}* 0.445 \\
0.038 \\
22\end{array}$ & $\begin{array}{r}*-0.438 \\
0.042 \\
22\end{array}$ & $\begin{array}{r}-0.220 \\
0.339 \\
21\end{array}$ & $\begin{array}{r}-0.353 \\
0.107 \\
22\end{array}$ & $\begin{array}{r}-0.180 \\
0.422 \\
22\end{array}$ & $\begin{array}{r}-0.280 \\
0.206 \\
22\end{array}$ \\
\hline $\begin{array}{l}\text { Percent- } \\
\text { volume } \\
\text { infestation }\end{array}$ & $\begin{array}{r}0.258 \\
0.176 \\
29\end{array}$ & $\begin{array}{r}-0.243 \\
0.204 \\
29\end{array}$ & $\begin{array}{r}-0.105 \\
0.596 \\
28\end{array}$ & $\begin{array}{r}-0.186 \\
0.333 \\
29\end{array}$ & $\begin{array}{r}-0.280 \\
0.158 \\
27\end{array}$ & $\begin{array}{r}-0.203 \\
0.311 \\
27\end{array}$ \\
\hline
\end{tabular}


Table 4 cont'd.

correlation coefficient

prob. $>1$ r 1 under Ho: rho $=0$

sample size

\begin{tabular}{|c|c|c|c|c|c|c|}
\hline & $\begin{array}{l}\text { PERI- } \\
\text { PROP }\end{array}$ & $\begin{array}{l}\text { PLNK- } \\
\text { PROP }\end{array}$ & $\begin{array}{l}\text { PERI- } \\
\text { CONC }\end{array}$ & $\begin{array}{l}\log \\
\text { PLNK- } \\
\text { CONC }\end{array}$ & $\begin{array}{c}\log \\
\text { PERI- } \\
\text { ACCM }\end{array}$ & $\begin{array}{c}\log \\
\text { PLNK- } \\
\text { ACCM }\end{array}$ \\
\hline $\begin{array}{l}\text { Floating- } \\
\text { leaved } \\
\text { biomass }\end{array}$ & $\begin{array}{r}-0.097 \\
0.668 \\
22\end{array}$ & $\begin{array}{r}0.126 \\
0.576 \\
22\end{array}$ & $\begin{array}{r}0.221 \\
0.336 \\
21\end{array}$ & $\begin{array}{r}0.088 \\
0.695 \\
22\end{array}$ & $\begin{array}{r}*-0.205 \\
0.360 \\
22\end{array}$ & $\begin{array}{r}0.019 \\
0.932 \\
22\end{array}$ \\
\hline $\begin{array}{l}\text { Submerged } \\
\text { biomass }\end{array}$ & $\begin{array}{r}0.193 \\
0.391 \\
22\end{array}$ & $\begin{array}{r}-0.173 \\
0.440 \\
22\end{array}$ & $\begin{array}{r}-0.106 \\
0.647 \\
21\end{array}$ & $\begin{array}{r}-0.140 \\
0.534 \\
22\end{array}$ & $\begin{array}{r}-0.311 \\
0.159 \\
22\end{array}$ & $\begin{array}{r}-0.137 \\
0.543 \\
22\end{array}$ \\
\hline $\begin{array}{l}\text { Emergent } \\
\text { biomass }\end{array}$ & $\begin{array}{r}0.165 \\
0.463 \\
22\end{array}$ & $\begin{array}{r}-0.143 \\
0.525 \\
22\end{array}$ & $\begin{array}{r}0.028 \\
0.904 \\
21\end{array}$ & $\begin{array}{r}-0.005 \\
0.982 \\
22\end{array}$ & $\begin{array}{r}-0.278 \\
0.211 \\
22\end{array}$ & $\begin{array}{r}-0.113 \\
0.616 \\
22\end{array}$ \\
\hline $\begin{array}{l}\text { Mean } \\
\text { depth }\end{array}$ & $\begin{array}{r}-0.195 \\
-0.372 \\
22\end{array}$ & $\begin{array}{r}0.169 \\
0.440 \\
22\end{array}$ & $\begin{array}{r}-0.096 \\
0.669 \\
22\end{array}$ & $\begin{array}{r}-0.059 \\
0.789 \\
22\end{array}$ & $\begin{array}{r}-0.246 \\
0.270 \\
22\end{array}$ & $\begin{array}{r}-0.108 \\
0.633 \\
22\end{array}$ \\
\hline $\begin{array}{l}\text { Shoreline } \\
\text { length }\end{array}$ & $\begin{array}{r}-0.372 \\
0.088 \\
22\end{array}$ & $\begin{array}{r}0.371 \\
0.089 \\
22\end{array}$ & $\begin{array}{r}0.131 \\
0.572 \\
21\end{array}$ & $\begin{array}{r}0.337 \\
0.125 \\
22\end{array}$ & $\begin{array}{r}0.155 \\
0.492 \\
22\end{array}$ & $\begin{array}{r}0.315 \\
0.154 \\
22\end{array}$ \\
\hline $\begin{array}{l}\text { Shoreline } \\
\text { develop- } \\
\text { ment }\end{array}$ & $\begin{array}{r}-0.002 \\
0.992 \\
22\end{array}$ & $\begin{array}{r}-0.013 \\
0.955 \\
22\end{array}$ & $\begin{array}{r}-0.273 \\
0.232 \\
21\end{array}$ & $\begin{array}{r}-0.272 \\
0.220 \\
22\end{array}$ & $\begin{array}{r}-0.413 \\
0.056 \\
22\end{array}$ & $\begin{array}{r}-0.330 \\
0.133 \\
22\end{array}$ \\
\hline
\end{tabular}


untransformed values did. Table 4 shows that concentrations and log-transformed accumulation rates of both periphyton (Fig. 5) and plankton (Fig. 6) were positively correlated with $\mathrm{TSI}(\mathrm{AVG}) . \mathrm{pH}$, an important correlate of TSI, was found to be negatively correlated with the proportion of periphyton and positively correlated with the proportion of plankton in recent sediments of survey lakes. $\mathrm{pH}$ was also positively correlated with the log-transformed concentrations and accumulation rates of plankton. Chl a, total $\mathrm{N}$ and Secchi depth values used to calculate TSI(AVG) are shown in Appendix 4. Appendix 6 lists the proportions, sedimentary concentrations and accumulation rates of periphyton and plankton in the survey lakes.

The only macrophyte variable that demonstrated significant correlation coefficients with diatom life-form variables was percentarea coverage, which was positively correlated with the proportion of periphyton, and negatively correlated with the proportion of plankton (Table 4). Percent-area coverage was also negatively correlated with the concentration of planktonic diatoms. Coefficients of determination indicate that the 3 diatom life-form variables correlated with percent-area coverage would each explain only 19$24 \%$ of the variance in that variable. Percent loss on ignition and organic matter accumulation rates (Table 5) were not significantly correlated with any of the water chemistry or macrophyte variables.

Appendix 2 lists the 47 taxonomic groupings that were used in multivariate analyses. Individual taxa were combined into groupings based on taxonomic and ecological affinities, and selected for multivariate analyses based on the results of plots of their percentages versus macrophyte variables. 


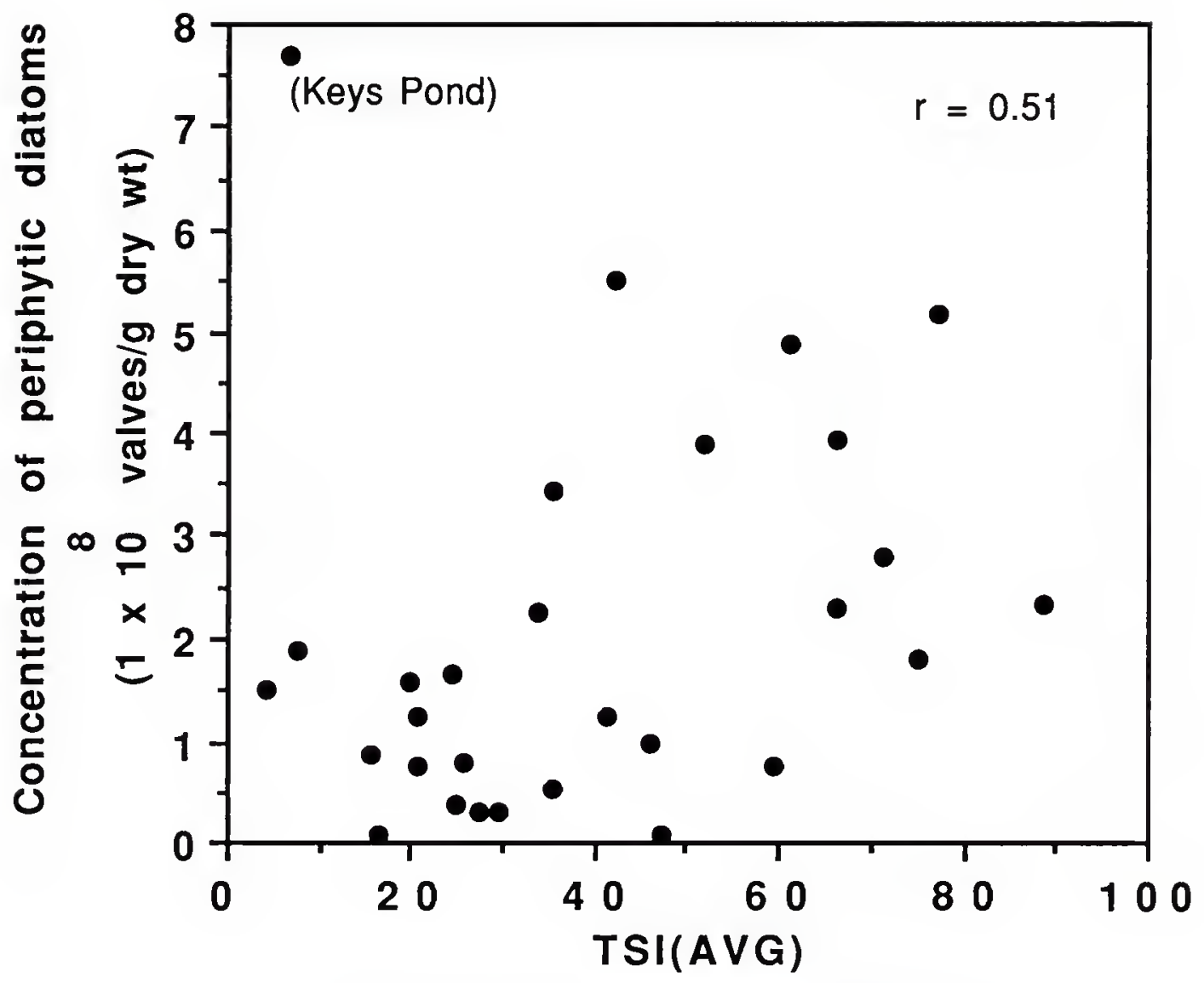

Figure 5. Concentration of periphytic diatoms in surface sediments versus TSI(AVG) for 29 lakes. 


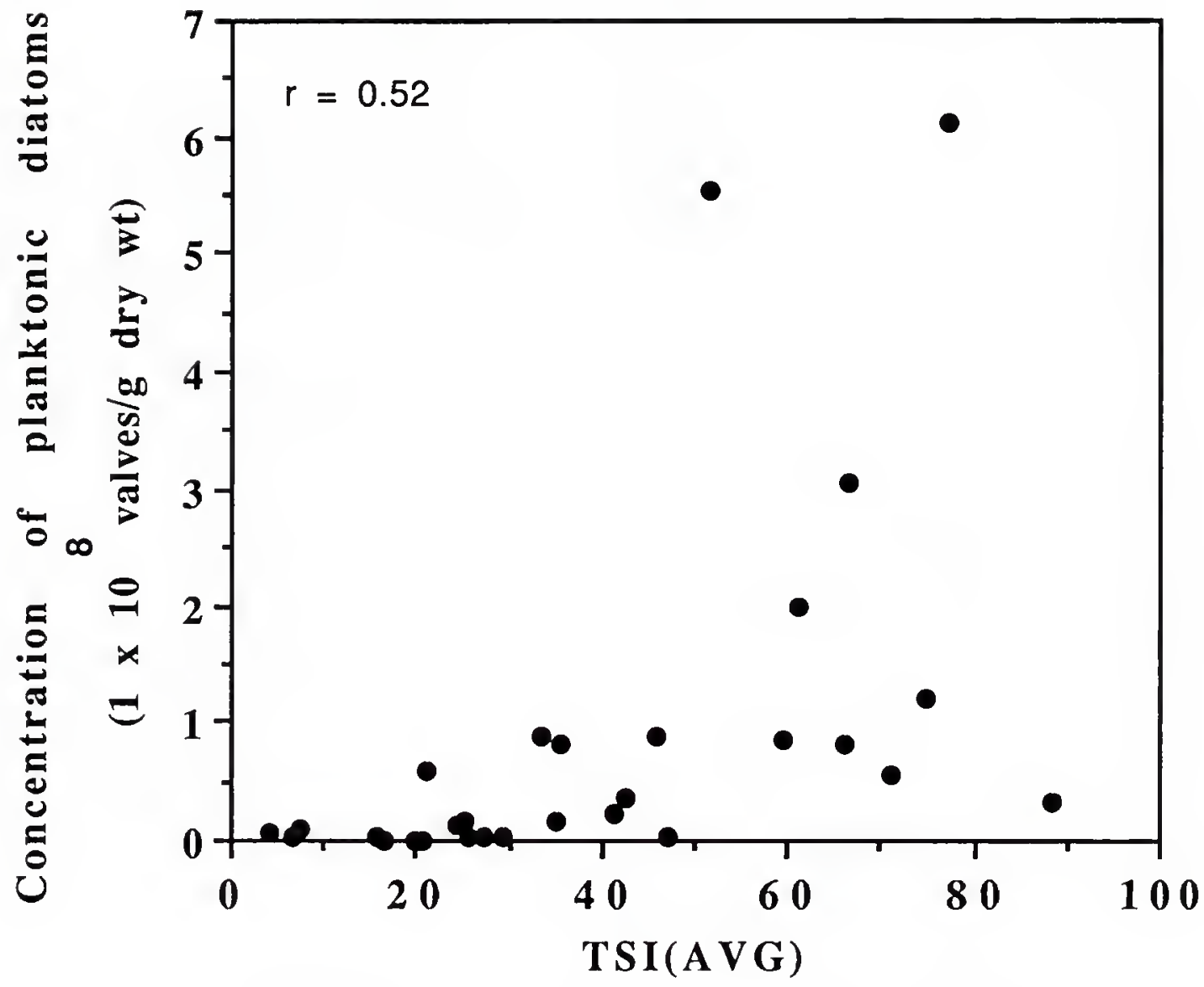

Figure 6. Concentration of planktonic diatoms in surface sediments versus TSI(AVG) for 29 lakes. 
Table 5. Percent loss on ignition, bulk sediment accumulation rates, and organic mater accumulation rates for lakes in synoptic survey.

Lake

$\begin{array}{cll}\begin{array}{c}\text { \% Loss on } \\ \text { ignition }\end{array} & \text { bulk sediment } & \text { Organic matter } \\ \text { @ 550 } 50^{\circ} \mathrm{C} & \left(\mathrm{g} \mathrm{cm}^{-2} \mathrm{yr}^{-1}\right) & \text { accumulation } \\ & & \left(\mathrm{g} \mathrm{cm}^{-2} \mathrm{yr}^{-1}\right)\end{array}$

$\begin{array}{lrrl}\text { Alligator } & 59.14 & 0.07 & 0.04 \\ \text { Apopka } & 64.10 & 0.09 & 0.06 \\ \text { Bonny } & 53.46 & 0.03 & 0.02 \\ \text { Carr } & 26.53 & 0.02 & 0.01 \\ \text { Catherine } & 55.21 & 0.03 & 0.02 \\ \text { Clay } & 43.98 & 0.03 & 0.01 \\ \text { Crooked } & 50.11 & 0.02 & 0.01 \\ \text { Deep } & 69.65 & 0.10 & 0.07 \\ \text { Fairview } & 8.20 & 0.22 & 0.02 \\ \text { Harris } & 80.93 & 0.04 & 0.03 \\ \text { Hartridge } & 53.56 & 0.05 & 0.03 \\ \text { Keys Pond } & 30.49 & 0.02 & 0.01 \\ \text { Lindsey } & 17.12 & 0.03 & 0.01 \\ \text { Live Oak } & 86.06 & 0.16 & 0.13 \\ \text { Lochloosa } & 36.10 & 0.04 & 0.01 \\ \text { Loften Ponds } & 33.60 & 0.02 & 0.01 \\ \text { Moore } & 17.21 & 0.04 & 0.01 \\ \text { Mystic } & & & \\ \text { Ocean Pond } & 39.00 & 0.10 & 0.04 \\ \text { Okahumpka } & 67.10 & 0.06 & 0.04 \\ \text { Orange } & & & \\ \text { Patrick } & 44.30 & 0.25 & 0.11 \\ \text { Rowell } & 69.00 & 0.31 & 0.21 \\ \text { Stella } & 14.00 & 0.17 & 0.02 \\ \text { Tomohawk } & 63.00 & 0.03 & 0.02 \\ \text { Townsend } & 79.60 & 0.04 & 0.03 \\ \text { Watertown } & 60.30 & 0.07 & 0.04 \\ \text { Wauberg } & 72.40 & 0.04 & \\ \text { Wildcat } & & & \\ \end{array}$




\section{Results of Cluster Analyses}

Cluster analysis based on the percentage data for 47 taxonomic groups produced 16 clusters of taxa. Nine of these clusters demonstrated significant correlation coefficients with TSI(AVG), and six clusters showed significant correlations with $\mathrm{pH}$ (Table 6). Four clusters that were correlated with $\operatorname{TSI}(\mathrm{AVG})$ and $\mathrm{pH}$ also showed significant correlations with specific conductance. Three clusters were correlated with both lake surface area and shoreline length. Mean depth and shoreline development were each correlated with single separate clusters. Of the 80 correlation coefficients between diatom clusters and macrophyte variables, only two were significant, one with percent-volume infestation, and one with emergent biomass. Navicula pupula vars. (S-NAVPU) and Stauroneis spp. (SSTAU) were the taxonomic groups in the cluster correlated with percent-volume infestation, and these were included among the pool of independent variables (Appendix 3.1) in a stepwise procedure to construct a model that predicts percent-volume infestation. Caloneis sp. A and Navicula seminulum vars. (S-NAVSEM) were the taxonomic groups correlated with emergent biomass, but this correlation was driven by a single datum because both species showed anamalously high percentages in Crooked Lake.

Due to the overwhelming influence TSI(AVG) and $\mathrm{pH}$ had on composition of taxonomic clusters, cluster analysis using taxonomic percentages was repeated while partialling out the effects of $\mathrm{pH}$ and TSI(AVG). Fourteen diatom clusters resulted from this procedure. Seven of the clusters still demonstrated a significant correlation with TSI(AVG), and six of these had significant correlations with $\mathrm{pH}$. Two 
Table 6. Pearson product-moment correlation coefficients for clusters based on percentage data for diatom taxonomic groups with macrophyte and water quality variables. $*=\mathrm{p}<0.05$.

correlation coefficient

prob. $>1$ r 1 under Ho: rho $=0$

sample size

\begin{tabular}{|c|c|c|c|c|c|}
\hline & CLUS1 & CLUS2 & CLUS3 & CLUS4 & CLUS5 \\
\hline TSI(AVG) & $\begin{array}{r}* 0.691 \\
<0.001 \\
29\end{array}$ & $\begin{array}{r}0.163 \\
0.397 \\
29\end{array}$ & $\begin{array}{r}* 0.547 \\
0.002 \\
29\end{array}$ & $\begin{array}{r}-0.173 \\
0.368 \\
29\end{array}$ & $\begin{array}{r}* 0.528 \\
0.003 \\
29\end{array}$ \\
\hline $\mathrm{pH}$ & $\begin{array}{r}*-0.692 \\
<0.001 \\
29\end{array}$ & $\begin{array}{r}* 0.322 \\
0.009 \\
29\end{array}$ & $\begin{array}{r}* 0.409 \\
0.0276 \\
29\end{array}$ & $\begin{array}{r}-0.356 \\
0.058 \\
29\end{array}$ & $\begin{array}{r}* 0.389 \\
0.037 \\
29\end{array}$ \\
\hline $\begin{array}{l}\text { Specific } \\
\text { conduc- } \\
\text { tance }\end{array}$ & $\begin{array}{r}*-0.531 \\
0.003 \\
29\end{array}$ & $\begin{array}{r}0.212 \\
0.269 \\
29\end{array}$ & $\begin{array}{r}0.218 \\
0.257 \\
29\end{array}$ & $\begin{array}{r}-0.253 \\
0.185 \\
29\end{array}$ & $\begin{array}{r}0.154 \\
0.426 \\
29\end{array}$ \\
\hline $\begin{array}{l}\text { Percent- } \\
\text { area } \\
\text { coverage }\end{array}$ & $\begin{array}{r}0.145 \\
0.519 \\
22\end{array}$ & $\begin{array}{r}-0.084 \\
0.710 \\
22\end{array}$ & $\begin{array}{r}-0.358 \\
0.102 \\
22\end{array}$ & $\begin{array}{r}0.193 \\
0.388 \\
22\end{array}$ & $\begin{array}{r}-0.271 \\
0.215 \\
22\end{array}$ \\
\hline $\begin{array}{l}\text { Percent- } \\
\text { volume } \\
\text { infestation }\end{array}$ & $\begin{array}{r}-0.124 \\
0.521 \\
29\end{array}$ & $\begin{array}{r}-0.083 \\
0.671 \\
29\end{array}$ & $\begin{array}{r}-0.194 \\
0.313 \\
29\end{array}$ & $\begin{array}{r}-0.165 \\
0.392 \\
29\end{array}$ & $\begin{array}{r}-0.120 \\
0.536 \\
29\end{array}$ \\
\hline $\begin{array}{l}\text { Floating- } \\
\text { leaved } \\
\text { biomass }\end{array}$ & $\begin{array}{r}-0.149 \\
0.508 \\
22\end{array}$ & $\begin{array}{r}-0.116 \\
0.607 \\
22\end{array}$ & $\begin{array}{r}-0.092 \\
0.685 \\
22\end{array}$ & $\begin{array}{r}-0.019 \\
0.934 \\
22\end{array}$ & $\begin{array}{r}0.408 \\
0.060 \\
22\end{array}$ \\
\hline $\begin{array}{l}\text { Submerged } \\
\text { biomass }\end{array}$ & $\begin{array}{r}-0.024 \\
0.916 \\
22\end{array}$ & $\begin{array}{r}0.121 \\
0.591 \\
22\end{array}$ & $\begin{array}{r}-0.279 \\
0.209 \\
22\end{array}$ & $\begin{array}{r}-0.113 \\
0.617 \\
22\end{array}$ & $\begin{array}{r}-0.106 \\
0.640 \\
22\end{array}$ \\
\hline $\begin{array}{l}\text { Emergent } \\
\text { biomass }\end{array}$ & $\begin{array}{r}-0.045 \\
0.843 \\
22\end{array}$ & $\begin{array}{r}-0.096 \\
0.670 \\
22\end{array}$ & $\begin{array}{r}-0.233 \\
0.297 \\
22\end{array}$ & $\begin{array}{r}0.404 \\
0.062 \\
22\end{array}$ & $\begin{array}{r}0.040 \\
0.859 \\
22\end{array}$ \\
\hline
\end{tabular}


Table 6 cont'd.

\begin{tabular}{|c|c|c|c|c|c|}
\hline & & $\begin{array}{r}\text { correla } \\
\text { prob. > } 1 \mathrm{R}\end{array}$ & $\begin{array}{l}\text { coefficie } \\
\text { inder Ho: } \\
\text { le size }\end{array}$ & $=0$ & \\
\hline & CLUS6 & CLUS7 & CLUS8 & CLUS9 & CLUS10 \\
\hline & -0.081 & $* 0.485$ & $* 0.387$ & -0.101 & -0.044 \\
\hline TSI(AVG) & 0.677 & 0.008 & 0.038 & 0.603 & 0.819 \\
\hline & 29 & 29 & 29 & 29 & 29 \\
\hline & -0.124 & $* 0.545$ & 0.304 & $* 0.381$ & 0.250 \\
\hline $\mathrm{pH}$ & 0.521 & 0.002 & 0.109 & 0.041 & 0.191 \\
\hline & 29 & 29 & 29 & 29 & 29 \\
\hline Specific & -0.150 & $* 0.415$ & 0.209 & $* 0.392$ & 0.335 \\
\hline conduc- & 0.437 & 0.025 & 0.276 & 0.036 & 0.075 \\
\hline $\operatorname{tance}$ & 29 & 29 & 29 & 29 & 29 \\
\hline Percent- & -0.058 & -0.006 & -0.296 & 0.226 & -0.018 \\
\hline area & 0.797 & 0.980 & 0.180 & 0.312 & 0.935 \\
\hline coverage & 22 & 22 & 22 & 22 & 22 \\
\hline Percent- & -0.009 & 0.276 & -0.151 & 0.107 & 0.018 \\
\hline volume & 0.963 & 0.147 & 0.435 & 0.582 & 0.927 \\
\hline infestation & 29 & 29 & 29 & 29 & 29 \\
\hline Floating- & 0.1768 & 0.213 & -0.225 & -0.249 & -0.103 \\
\hline leaved & 0.431 & 0.341 & 0.312 & 0.262 & 0.645 \\
\hline biomass & 22 & 22 & 22 & 22 & 22 \\
\hline Submerged & 0.059 & 0.362 & -0.190 & -0.097 & -0.225 \\
\hline biomass & 0.793 & 0.097 & 0.396 & 0.666 & 0.313 \\
\hline & 22 & 22 & 22 & 22 & 22 \\
\hline Emergent & $* 0.724$ & 0.0731 & -0.251 & -0.109 & -0.259 \\
\hline biomass & $<0.001$ & 0.746 & 0.259 & 0.626 & 0.245 \\
\hline & 22 & 22 & 22 & 22 & 22 \\
\hline
\end{tabular}


Table 6 cont'd.

correlation coefficient

prob. > l R l under Ho: rho $=0$

sample size

\begin{tabular}{|c|c|c|c|c|c|c|}
\hline & CLUS11 & CLUS12 & CLUS13 & CLUS14 & CLUS15 & CLUS16 \\
\hline TSI(AVG) & $\begin{array}{r}*-0.471 \\
0.009 \\
29\end{array}$ & $\begin{array}{r}0.006 \\
0.971 \\
29\end{array}$ & $\begin{array}{r}* 0.413 \\
0.025 \\
29\end{array}$ & $\begin{array}{r}0.205 \\
0.284 \\
29\end{array}$ & $\begin{array}{r}*-0.4032 \\
0.0301 \\
29\end{array}$ & $\begin{array}{r}*-0.368 \\
0.048 \\
29\end{array}$ \\
\hline $\mathrm{pH}$ & $\begin{array}{r}*-0.515 \\
0.004 \\
29\end{array}$ & $\begin{array}{r}0.112 \\
0.559 \\
29\end{array}$ & $\begin{array}{r}0.318 \\
0.092 \\
29\end{array}$ & $\begin{array}{r}0.142 \\
0.459 \\
29\end{array}$ & $\begin{array}{r}-0.335 \\
0.075 \\
29\end{array}$ & $\begin{array}{r}-0.330 \\
0.079 \\
29\end{array}$ \\
\hline $\begin{array}{l}\text { Specific } \\
\text { conduc- } \\
\text { tance }\end{array}$ & $\begin{array}{r}-0.310 \\
0.100 \\
29\end{array}$ & $\begin{array}{r}-0.208 \\
0.278 \\
29\end{array}$ & $\begin{array}{r}0.201 \\
0.295 \\
29\end{array}$ & $\begin{array}{r}0.363 \\
0.052 \\
29\end{array}$ & $\begin{array}{r}*-0.398 \\
0.032 \\
29\end{array}$ & $\begin{array}{r}-0.331 \\
0.078 \\
29\end{array}$ \\
\hline $\begin{array}{l}\text { Percent- } \\
\text { area } \\
\text { coverage }\end{array}$ & $\begin{array}{r}0.097 \\
0.667 \\
22\end{array}$ & $\begin{array}{r}0.246 \\
0.268 \\
22\end{array}$ & $\begin{array}{r}*-0.462 \\
0.030 \\
22\end{array}$ & $\begin{array}{r}-0.190 \\
0.396 \\
22\end{array}$ & $\begin{array}{r}0.303 \\
0.170 \\
22\end{array}$ & $\begin{array}{r}0.334 \\
0.128 \\
22\end{array}$ \\
\hline $\begin{array}{l}\text { Percent- } \\
\text { volume } \\
\text { infestation }\end{array}$ & $\begin{array}{r}-0.185 \\
0.335 \\
29\end{array}$ & $\begin{array}{r}* 0.439 \\
0.017 \\
29\end{array}$ & $\begin{array}{r}-0.227 \\
0.234 \\
29\end{array}$ & $\begin{array}{r}-0.096 \\
0.618 \\
29\end{array}$ & $\begin{array}{r}0.341 \\
0.063 \\
29\end{array}$ & $\begin{array}{r}0.265 \\
0.163 \\
29\end{array}$ \\
\hline $\begin{array}{l}\text { Floating- } \\
\text { leaved } \\
\text { biomass }\end{array}$ & $\begin{array}{r}-0.099 \\
0.659 \\
22\end{array}$ & $\begin{array}{r}-0.015 \\
0.947 \\
22\end{array}$ & $\begin{array}{r}0.004 \\
0.985 \\
22\end{array}$ & $\begin{array}{r}0.070 \\
0.755 \\
22\end{array}$ & $\begin{array}{r}0.227 \\
0.309 \\
22\end{array}$ & $\begin{array}{r}-0.175 \\
0.435 \\
22\end{array}$ \\
\hline $\begin{array}{l}\text { Submerged } \\
\text { biomass }\end{array}$ & $\begin{array}{r}0.140 \\
0.532 \\
22\end{array}$ & $\begin{array}{r}-0.043 \\
0.847 \\
22\end{array}$ & $\begin{array}{r}-0.001 \\
0.995 \\
22\end{array}$ & $\begin{array}{r}0.080 \\
0.722 \\
22\end{array}$ & $\begin{array}{r}0.262 \\
0.237 \\
22\end{array}$ & $\begin{array}{r}0.008 \\
0.968 \\
22\end{array}$ \\
\hline $\begin{array}{l}\text { Emergent } \\
\text { biomass }\end{array}$ & $\begin{array}{r}-0.011 \\
0.958 \\
22\end{array}$ & $\begin{array}{r}0.021 \\
0.925 \\
22\end{array}$ & $\begin{array}{r}0.044 \\
0.843 \\
22\end{array}$ & $\begin{array}{r}-0.038 \\
0.864 \\
22\end{array}$ & $\begin{array}{r}0.363 \\
0.096 \\
22\end{array}$ & $\begin{array}{r}-0.003 \\
0.989 \\
22\end{array}$ \\
\hline
\end{tabular}


of the three clusters that were significantly correlated with specific conductance were also correlated with TSI(AVG) and pH. Among the morphometeric variables, two clusters were signifcantly correlated with mean depth, and one cluster was correlated with shoreline development. Two clusters were significantly correlated with both lake surface area and shoreline length. Of the 70 correlation coefficients between macrophyte variables and diatom clusters, only three correlation coefficients were significant. One cluster that was composed of Caloneis sp. A and Navicula seminulum vars. demonstrated a significant correlation with emergent biomass as in the unpartialled analysis, and this again appeared spurious because the correlation was driven by anomalously high percentages of both taxa in Crooked Lake. The second cluster, which consisted of Anomoeneis spp. (S-ANOM), Gomphonema spp. (S-GOMA), Navicula pupula vars., and Stauroneis spp. (S-STAU), was correlated with both percent-area coverage and percent-volume infestation. Taxonomic groups in this cluster that showed a directional change in abundance over the range of percent-area coverage and percent-volume infestation were included among the independent variables in the stepwise regression procedures to predict these macrophyte variables (Appendix 3.1 and 3.4).

Cluster analysis based on sedimentary concentrations of diatoms produced 12 clusters, 4 of which were significantly correlated with TSI(AVG), and 5 of which were correlated with $\mathrm{pH}$. The morphometeric variables lake-surface area and shoreline length were each significantly correlated with 2 separate clusters. Of 60 correlation coefficients between diatom clusters and macrophyte 
variables, 4 were significant. A cluster that was composed of the taxon Caloneis sp. A was significantly correlated with emergent biomass, but this correlation was driven by a single datum point because of the unusually high percentage of this taxon in Crooked Lake. Another cluster consisted of Fragilaria brevistriata and Gomphonema spp. (S-GOMA) and was signifcantly correlated with percent-volume infestation. This correlation did not appear meaningful because $F$. brevistriata was represented by only two data points, and $G$. spp. was correlated with percent-volume infestation only because of anamalously high values in Lake Carr. In addition, $F$. brevistriata and $G$ spp. showed different slopes over the range of percent-volume infestation. A third cluster, which seemed spuriously correlated with emergent biomass, consisted of two euplanktonic and two periphytic taxa. Asterionella spp. (S-AST) and Aulacoseira islandica were the two euplanktonic taxa in this cluster and they showed high values only in Crooked Lake. Tabellaria flocculosa and $T$. fenestrata were the periphytic taxa in this cluster and their slopes were different over the range of emergent biomass. A fourth cluster was positively correlated with floating-leaved biomass $(\mathrm{r}=0.554, \mathrm{p}=0.008, \mathrm{n}=22)$ and contained 9 taxonomic groups (Appendix 3.7), seven of which were euplanktonic. These taxa were used as independent variables in a stepwise regression procedure to predict floating-leaved biomass.

When the clustering procedure was repeated partialling out the effects of TSI(AVG) and pH, a cluster composed of the 7 euplanktonic taxa last mentioned was again positively correlated with floatingleaved biomass. Four clusters were still significantly correlated with 
TSI(AVG) and 5 were correlated with pH. Eunotia spp. (S-EUN) and Gomphonema spp. (S-GOMA) composed a cluster that was significantly correlated with percent-volume infestation, but plots revealed that both of these taxonomic groups had low sedimentary concentrations except for unusually high concentrations in Lake Carr. Emergent biomass was significantly correlated with a cluster composed of Asterionella spp., Aulacoseira islandica, Tabellaria flocculosa and $T$. fenestrata as it was prior to partialling covariant effects. Another cluster composed of Caloneis sp. A and Nitzschia capitellata was correlated with emergent biomass, but these taxa demonstrated opposite slopes over the range of emergent biomass. None of the 66 remaining correlation coefficients between diatom clusters and macrophyte variables was significant.

Cluster analysis of diatom taxonomic groups based on annual diatom accumulation rates produced 11 clusters. Four of these clusters were significantly correlated with TSI(AVG), and three of these plus a fourth cluster were significanly correlated with $\mathrm{pH}$. Four clusters were correlated with shoreline length and two clusters were correlated with specific conductance. Of the 55 correlation coefficients between diatom clusters and macrophyte variables, only one correlation coefficient was significant. Floating-leaved biomass was found to be negatively correlated with a cluster composed of 4 periphytic and 3 planktonic taxonomic groups (Appendix 3.8). These diatom groups were used in a stepwise regression procedure to predict floating-leaved biomass.

The last cluster analysis was based on diatom accumulation rates with the effects of TSI(AVG) and $\mathrm{pH}$ partialled out, and it produced 
12 clusters of diatom taxa. TSI(AVG), $\mathrm{pH}$ and specific conductance had 3 significant correlations each with diatom clusters. Shoreline development and lake surface area were correlated with 2 clusters each, and mean depth was correlated with one cluster. Of 60 correlation coefficients related to the macrophyte variables, only two were statistically significant. Seven of the 9 taxa in one cluster that was correlated with floating-leaved biomass were the same taxa used in the stepwise multiple regression procedure described above for unpartialled effects of TSI(AVG) and $\mathrm{pH}$. Another cluster consisted of Fragilaria crotonensis, a euplanktonic taxon occurring in lakes high in water-column nutrients, that had an apparently spurious correlation with floating-leaved biomass.

\section{$\underline{\text { Results of Principal Components Analyses }}$}

Principal components analysis seems to be an appropriate indirect ordination method to apply because species distributions were observed to be linear or curvilinear, though not modal, over the range of percent-area coverage and percent-volume infestation. Correlation coefficients were examined between the first 8 principal components based on percentage data for 47 diatom taxonomic groups and environmental variables. Eigenvalues, which are equal to the variances of the components, indicate that the first 3 principal components account for $15.9 \%, 8.5 \%$ and $7.2 \%$ of the variance in diatom assemblages, respectively. The first principal component was found to be highly correlated with TSI(AVG), $\mathrm{pH}$ and specific conductance (Table 7), indicating that these environmental variables were responsible for most of the variance in the diatom assemblages. 
Table 7. Correlation coefficients for principle components based on diatom percentage data with water quality and macrophyte variables. $*=p<0.05$.

$$
\begin{gathered}
\text { correlation coefficient } \\
\text { prob. }>\text { l } \text { r l under Ho: } \text { rho }=0 \\
\text { sample size }
\end{gathered}
$$

1 st.

2nd. 3rd.

principle comp.
1 st. principle comp.

\begin{tabular}{|c|c|c|c|c|}
\hline $\begin{array}{l}\text { Percent } \\
\text { volume } \\
\text { infestation }\end{array}$ & $\begin{array}{r}-0.556 \\
0.774 \\
29\end{array}$ & $\begin{array}{r}0.130 \\
0.500 \\
29\end{array}$ & $\begin{array}{r}* 0.395 \\
0.034 \\
29\end{array}$ & $\begin{array}{r}-0.134 \\
0.653 \\
29\end{array}$ \\
\hline $\begin{array}{l}\text { Percent } \\
\text { area } \\
\text { coverage }\end{array}$ & $\begin{array}{r}-0.322 \\
0.144 \\
22\end{array}$ & $\begin{array}{r}0.132 \\
0.557 \\
22\end{array}$ & $\begin{array}{r}0.298 \\
0.176 \\
22\end{array}$ & $\begin{array}{r}-0.171 \\
0.444 \\
22\end{array}$ \\
\hline $\begin{array}{l}\text { Floating- } \\
\text { leaved } \\
\text { biomass }\end{array}$ & $\begin{array}{r}0.102 \\
0.649 \\
22\end{array}$ & $\begin{array}{r}0.064 \\
0.776 \\
22\end{array}$ & $\begin{array}{r}-0.146 \\
0.515 \\
22\end{array}$ & $\begin{array}{r}0.086 \\
0.703 \\
22\end{array}$ \\
\hline $\begin{array}{l}\text { Submerged } \\
\text { biomass }\end{array}$ & $\begin{array}{r}-0.108 \\
0.632 \\
22\end{array}$ & $\begin{array}{r}-0.163 \\
0.467 \\
22\end{array}$ & $\begin{array}{r}0.168 \\
0.453 \\
22\end{array}$ & $\begin{array}{r}-0.185 \\
0.409 \\
22\end{array}$ \\
\hline $\begin{array}{l}\text { Emergent } \\
\text { biomass }\end{array}$ & $\begin{array}{r}-0.144 \\
0.521 \\
22\end{array}$ & $\begin{array}{r}0.114 \\
0.612 \\
22\end{array}$ & $\begin{array}{r}0.082 \\
0.714 \\
22\end{array}$ & $\begin{array}{r}-0.081 \\
0.720 \\
22\end{array}$ \\
\hline TSI(AVG) & $\begin{array}{r}* 0.753 \\
<0.001 \\
29\end{array}$ & $\begin{array}{r}-0.023 \\
0.901 \\
29\end{array}$ & $\begin{array}{r}0.029 \\
0.880 \\
29\end{array}$ & $\begin{array}{r}* 0.414 \\
0.026 \\
29\end{array}$ \\
\hline
\end{tabular}

TSI(AVG) and $\mathrm{pH}$ partialled out 
Table 7 cont'd.

\begin{tabular}{|c|c|c|c|c|}
\hline & \multicolumn{3}{|c|}{$\begin{array}{l}\text { correlation coefficient } \\
\text { prob. > } 1 \text { r } 1 \text { under Ho: rho }=0 \\
\text { sample size }\end{array}$} & \multirow[b]{2}{*}{$\begin{array}{c}\text { 1st. } \\
\text { principle } \\
\text { comp. } \\
\text { TSI(AVG) and } \\
\text { pH partialled out }\end{array}$} \\
\hline & $\begin{array}{l}1 \text { st. } \\
\text { principle } \\
\text { comp. }\end{array}$ & $\begin{array}{l}\text { 2nd. } \\
\text { principle } \\
\text { comp. }\end{array}$ & $\begin{array}{l}\text { 3rd. } \\
\text { principle } \\
\text { comp. } \\
\qquad p\end{array}$ & \\
\hline \multirow{3}{*}{$\mathrm{pH}$} & $* 0.775$ & -0.132 & $* 0.374$ & $* 0.411$ \\
\hline & $<0.001$ & 0.494 & 0.045 & 0.026 \\
\hline & 29 & 29 & 29 & 29 \\
\hline \multirow{3}{*}{$\begin{array}{l}\text { Specific } \\
\text { conductance }\end{array}$} & $* 0.539$ & -0.283 & $* 0.373$ & 0.187 \\
\hline & 0.003 & 0.135 & 0.045 & 0.330 \\
\hline & 29 & 29 & 29 & 29 \\
\hline \multirow{3}{*}{$\begin{array}{l}\text { Mean } \\
\text { depth }\end{array}$} & -0.170 & $*-0.437$ & -0.154 & -0.105 \\
\hline & 0.437 & 0.037 & 0.481 & 0.633 \\
\hline & 23 & 23 & 23 & 23 \\
\hline \multirow{3}{*}{$\begin{array}{l}\text { Shoreline } \\
\text { length }\end{array}$} & 0.200 & $*-0.457$ & 0.446 & -0.192 \\
\hline & 0.369 & 0.032 & 0.037 & 0.390 \\
\hline & 22 & 22 & 22 & 22 \\
\hline \multirow{3}{*}{$\begin{array}{l}\text { Lake } \\
\text { surface } \\
\text { area }\end{array}$} & 0.150 & $*_{-0.454}$ & 0.314 & -0.260 \\
\hline & 0.445 & 0.015 & 0.103 & 0.180 \\
\hline & 28 & 28 & 28 & 28 \\
\hline
\end{tabular}


The second principal component was significantly correlated with with the morphometric variables mean depth, shoreline length and lake surface area. The third principal component was significantly correlated with $\mathrm{pH}$, specific conductance and percentvolume infestation. A coefficient of determination indicates that the third principal component would explain $16.0 \%$ of the variance in percent-volume infestation, which is not sufficiently robust for predictive purposes. None of the remaining 60 correlation coefficients between principal components $4-8$ and the environmental variables was statistically significant.

Principal components analysis of percentage data was repeated while TSI(AVG) and $\mathrm{pH}$ were partialled out. The first principal component, which accounted for $11.8 \%$ of the variance in diatom taxa still showed significant correlations with TSI(AVG) and $\mathrm{pH}$ (Table 7). The second principal component explained $9.5 \%$ of the variance in the diatom assemblages and was significantly correlated with mean depth. The third principal component explained $8.6 \%$ of the variance in the diatom assemblages and was not correlated with any of the macrophyte or environmental variables considered. The fourth principal component explained $7.5 \%$ of the variance, and was negatively correlated with floating-leaved biomass $(r=-0.442, p=$ $0.040, \mathrm{n}=22$ ). A model based on this principal component would explain approximately $19.5 \%$ of the variance in floating-leaved biomass. None of the correlation coefficients between principal components 5-8 and the environmental variables was significant.

Principal components analysis was performed on sedimentary diatom concentrations for the 47 diatom taxonomic groups. The first 
principal component explained $18.3 \%$ of the variance and was significantly correlated with TSI(AVG) $(\mathrm{r}=0.648, \mathrm{p}<0.001, \mathrm{n}=29)$ and $\mathrm{pH}(\mathrm{r}=0.499, \mathrm{p}=0.006, \mathrm{n}=29)$. The second principal component explained $10.3 \%$ of the variance in the diatom assemblages and was not significantly correlated with any of the environmental or macrophyte variables. The third principal component explained $9.9 \%$ of the variance in the diatom assemblages. This component had a significant negative correlation with floating-leaved biomass $(\mathrm{r}=$ $0.536, \mathrm{p}=0.010, \mathrm{n}=22)$, and a positive correlation with $\mathrm{pH}(\mathrm{r}=$ $0.400, \mathrm{p}=0.032, \mathrm{n}=29$ ) and shoreline length. Scores obtained for survey lakes using eigenvectors of the third principal component (Table 8) were used to construct the following model:

$$
\begin{aligned}
& \text { floating-leaved biomass }=2.419-0.750(\text { PRIN3) } \\
& \mathrm{R}^{2}=0.287, \mathrm{p}=0.010, \mathrm{n}=22
\end{aligned}
$$

where PRIN3 is the sum of the products between eigenvectors and sedimentary concentrations of the 47 diatom groups.

The majority of the taxa in Table 8 that show large, positive eigenvectors (e.g. Fragilaria construens, F. pinnata, Navicula lanceolata, N. pupula and vars., $N$. radiosa and vars., $N$. cuspidata, Nitzschia amphibia, N. capitellata, Cocconeis placentula var. lineata), have a periphytic life form. Many of the taxa with smaller, negative eigenvectors (e.g. Asterionella spp., Aulacoseira islandica, Cyclostephanos dubius, Fragilaria crotonensis) have a euplanktonic life form. It appears that samples with large numbers of periphytic diatoms and few planktonic diatoms would have large values of PRIN3, and it would be reasonable to expect that large PRIN3 values would be associated with greater floating-leaved biomass. Equation 
Table 8. Eigenvectors of third principle component based on sedimentary concentrations of 47 diatom taxonomic groups. Taxonomic acronyms are defined in Appendix 2.

\begin{tabular}{|c|c|c|c|}
\hline $\begin{array}{l}\text { Taxonomic } \\
\text { group }\end{array}$ & Eigenvector & $\begin{array}{c}\text { Taxonomic } \\
\text { group }\end{array}$ & Eigenvector \\
\hline S-ACH & 0.081 & NAVGOT & 0.061 \\
\hline S-ANOM & 0.089 & NAVLAN & 0.261 \\
\hline S-AST & -0.177 & S-NAVPU & 0.209 \\
\hline AULAAM & 0.186 & S-NAVRA & 0.320 \\
\hline AULADIS & -0.025 & S-NAVSEM & 0.192 \\
\hline S-AULAGR & -0.096 & NAVSUBT & 0.122 \\
\hline AULAISL & -0.141 & NITZAM & 0.235 \\
\hline AULAITAL & 0.039 & NITZCAP & 0.195 \\
\hline CALSPA & -0.013 & NITZFONT & -0.139 \\
\hline COCPLACL & 0.138 & NITZFRUS & 0.193 \\
\hline CYCMEN & 0.124 & NITZPAL & -0.128 \\
\hline CYCPSEUD & -0.023 & S-PIN & 0.109 \\
\hline CYCSTEL & 0.013 & S-STAU & 0.101 \\
\hline CYCSTELO & 0.005 & S-SUR & -0.037 \\
\hline S-CYM & 0.034 & SYNDEL & 0.269 \\
\hline CYSTEPDU & -0.177 & SYNFILEX & 0.123 \\
\hline S-EP & 0.035 & S-SYNRUM & -0.014 \\
\hline S-EUN & 0.007 & TABFEN & -0.098 \\
\hline ACTPUNC & -0.075 & & \\
\hline NAVCUS & 0.137 & & \\
\hline NAVCONF & 0.115 & & \\
\hline TABFLOC & -0.168 & & \\
\hline S-NEI & 0.103 & & \\
\hline FRAGBREV & 0.069 & & \\
\hline S-FRAGCO & 0.298 & & \\
\hline FRAGCROT & -0.166 & & \\
\hline FRAGPIN & 0.225 & & \\
\hline S-FRUSRH & 0.096 & & \\
\hline S-GOMA & 0.006 & & \\
\hline
\end{tabular}


3.1 shows a negative coefficient for PRIN3, however, which is contrary to the expectation that periphytic taxa would demonstrate greater representation in lakes with greater floating-leaved biomass.

Partial correlation coefficients showed that the 3rd principal component was significantly correlated with floating-leaved biomass $(\mathrm{r}=-0.618, \mathrm{p}=0.003, \mathrm{n}=22)$ when the effect of $\mathrm{pH}$ was held constant. Despite the non-significant correlation between $\mathrm{pH}$ and floating-leaved biomass (Table 3), partial correlations showed that pH was significantly correlated with the 3rd principal component $(r=$ $0.521, \mathrm{p}=0.016, \mathrm{n}=29$ ) when floating-leaved biomass was held constant. This implies that the model predicting floating-leaved biomass is confounded by the effect of $\mathrm{pH}$, and should only be applied historically when it can be demonstrated that significant changes in $\mathrm{pH}$ have not occurred.

When the principal components analysis based on the sedimentary concentration of diatom groups was repeated partialling out the effects of TSI(AVG) and $\mathrm{pH}$, the first principal component explained $16.0 \%$ of the variance in the diatom assemblages and was positively correlated with floating-leaved biomass $(r=0.460, p=$ $0.031, \mathrm{n}=22$ ) and with TSI(AVG). This correlation with floatingleaved biomass was less robust than in the previous correlation with unpartialled effects. None of the remaining principal components in the partialled analysis had significant correlations with macrophyte variables.

The principal components procedure was repeated using logtransformed sedimentary diatom concentrations. The first principal component accounted for $30.4 \%$ of the variance in the diatom 
assemblage and demonstrated stronger correlations with TSI(AVG) (r $=0.783, \mathrm{p}<0.001, \mathrm{n}=29)$ and $\mathrm{pH}(\mathrm{r}=0.885, \mathrm{p}<0.001, \mathrm{n}=29)$ than the procedure with untransformed concentration data. None of the correlation coefficients between principal components and macrophyte variables were significant in this procedure, even when the effects of TSI(AVG) and $\mathrm{pH}$ were partialled out.

Principal components analysis using annual diatom accumulation rates produced a first principal component that explained $21.4 \%$ of the variance and was again significantly correlated with TSI(AVG) ( $\mathrm{r}$ $=0.460, \mathrm{p}=0.012, \mathrm{n}=29), \mathrm{pH}(\mathrm{r}=0.464, \mathrm{p}=0.011, \mathrm{n}=29)$, and specific conductance $(r=0.501, p=0.006, n=29)$. The only significant correlation coefficient involving a macrophyte variable was with the fourth principal component that was significantly correlated with percent-area coverage $(r=-0.448, p=0.036 . n=22)$ and more strongly correlated with $\operatorname{TSI}(\mathrm{AVG})(\mathrm{r}=0.501, \mathrm{p}=0.006, \mathrm{n}=$ 29). A predictive model using eigenvectors of this principal component would not be useful for predicting percent-area coverage because it would be confounded by TSI(AVG).

Principal components based on diatom accumulation rates with the effects of TSI(AVG) and $\mathrm{pH}$ partialled out produced a single significant correlation with a macrophyte variable. The sixth principal component, which accounted for $5.5 \%$ of the variance in the diatom assemblages, had a significant negative correlation with floating-leaved biomass $(\mathrm{r}=-0.574, \mathrm{p}=0.005, \mathrm{n}=22)$. A predictive model using the eigenvectors for this principal component would explain $33.0 \%$ of the variance in floating-leaved biomass but could 
only be applied historically to lakes that had not undergone changes in trophic state or $\mathrm{pH}$.

\section{Results of Stepwise Multiple Regression}

\section{Percent-Volume Infestation}

The maximum $\mathrm{R}^{2}$ method of the SAS STEPWISE procedure (SAS Inst., Inc. 1985) was applied to percentage data for 17 diatom taxonomic groups selected from plots of their abundance versus percent-volume infestation (Appendix 3.1). The plot of Mallows' Cp statistic versus the number of variables in each model is shown in Figure 7. Models with larger $\mathrm{Cp}$ values have larger total error than models with smaller Cp values (Daniel and Wood 1971). Models in which $\mathrm{Cp}$ is larger than the number of independent variables plus the intercept (p) are subject to bias error. Models with $\mathrm{Cp}$ values less than $\mathrm{p}$ are subject to random errors. Figure 7 shows that the model for predicting percent-volume infestation that consisted of one diatom taxon $(\mathrm{p}=2)$ showed substantial bias. All other multivariate models predicting percent-volume infestation from percentage data were subject to random error.

Stepwise regression to predict percent-volume infestation was attempted by using sedimentary concentration data for 17 diatom taxonomic groups (Appendix 3.2). All models demonstrated random error. Better results were obtained when log-transformed sedimentary concentrations were used in the stepwise procedure. Figure 8 is the plot of $\mathrm{Cp}$ versus $\mathrm{p}$ for models using log-transformed diatom concentrations. The model using 2 diatom taxonomic groups $(\mathrm{p}=3)$ shows bias. The model using 3 taxonomic groups $(\mathrm{p}=4)$ 


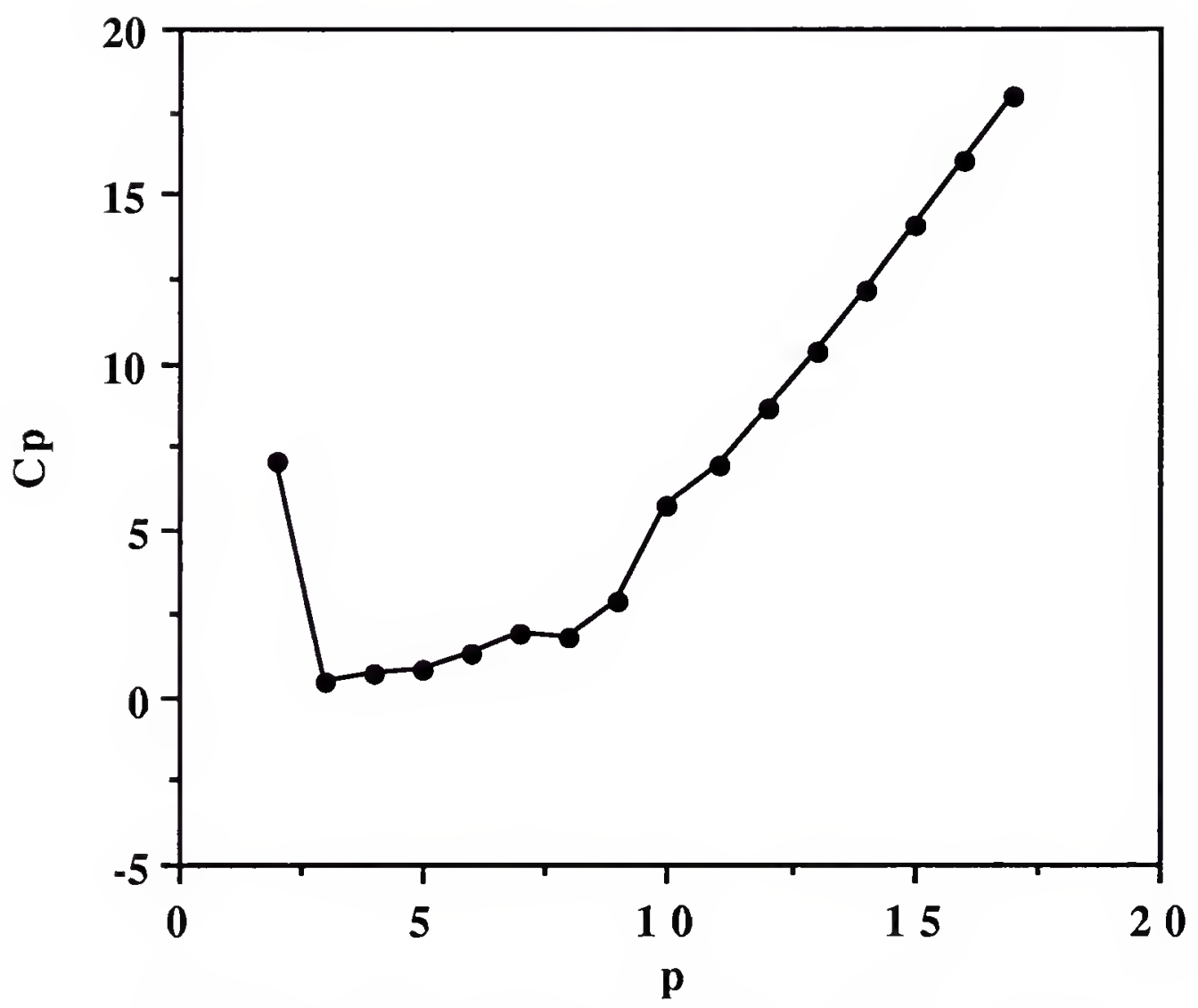

Figure 7. Mallows' $\mathrm{Cp}$ statistic versus $\mathrm{p}$ for model predicting percent volume infestation from percentage data.

$\mathrm{P}$ is number of dependent variables +1 . 


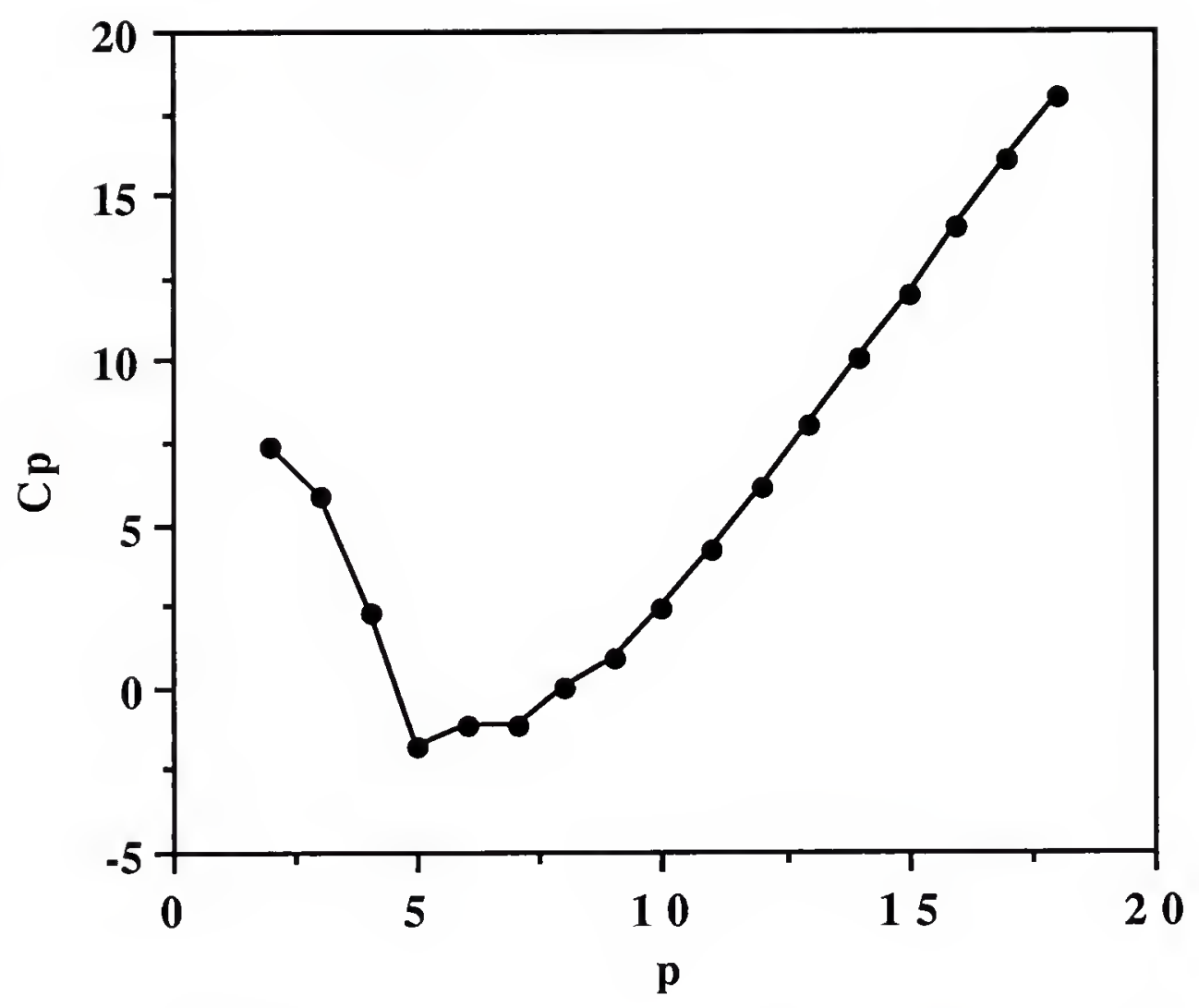

Figure 8. Mallows' $\mathrm{Cp}$ statistic versus $\mathrm{p}$ for model predicting percent volume infestation from log-transformed diatom concentrations. 
shows a slight random error, but a lower total error term. The best model for predicting percent-volume infestation (PVI) from sedimentary concentrations of diatom groups is therefore:

$$
\begin{aligned}
& \text { PVI }=36.960-4.217 \log (\text { ACHEX })+7.833 \log (\text { STAUPH })- \\
& 3.641 \log (\text { SYNFILEX })
\end{aligned}
$$

$$
\mathrm{R}^{2}=0.519, \mathrm{p}<0.001, \mathrm{n}=29
$$

where values for the 3 taxa, whose acronyms are defined in Appendix 1, are expressed in valves $\mathrm{g}^{-1}$ dry weight of sediment. The adjusted $\mathrm{R}^{2}$ value for this model is 0.461 .

The stepwise procedure was applied to log-transformed annual accumulation rate values for 17 diatom taxonomic groups (Appendix 3.3). The best model utilized 2 diatom taxa and showed an $R^{2}$ of 0.312. The adjusted $\mathrm{R}^{2}$ for this model was 0.259 . The model was less robust than the model based on log-transformed sedimentary diatom concentrations.

\section{Percent-Area Coverage}

Eleven diatom taxonomic groups (Appendix 3.4) selected from plots were used in the stepwise procedure to construct models predicting percent-area coverage from diatom percentage data. The best model, as determined from $\mathrm{Cp}$ values was:

$$
\begin{gathered}
\text { percent-area coverage }=27.294+3.971(\mathrm{~S}-\mathrm{CYM})+0.871(\mathrm{~S}- \\
\text { FRUSRH })+50.967(\mathrm{STAUPH}) \\
\mathrm{R}^{2}=0.502, \mathrm{p}=0.005, \mathrm{n}=22
\end{gathered}
$$

where values for the 3 taxonomic groups, which are defined in Appendices 1 and 2, are expressed as a percentage of each diatom 
assemblage. The adjusted $\mathrm{R}^{2}$ for this model was 0.419 . This multivariate model was significantly confounded with TSI(AVG) $\left(\mathrm{R}^{2}=\right.$ $0.665, \mathrm{p}<0.001)$ and would therefore be unsuitable for predictive purposes.

The stepwise procedure was applied to sedimentary diatom concentration data for 8 taxonomic groups (Appendix 3.5). Cp statistics indicated that the best model was;

$$
\begin{aligned}
\text { PAC }= & 44.408+2.14 \times 10-6(\text { ACHLIN })-2.7 \times 10-7(\text { S-AULAGR })+ \\
& 9.53 \times 10-5(\text { EUNINC })+1.91 \times 10-5(\text { STAUPH }) \\
\mathrm{R}^{2}= & 0.607, \mathrm{p}=0.002, \mathrm{n}=22, \text { adj. } \mathrm{R}^{2}=0.514 .
\end{aligned}
$$

Acronyms for taxonomic groups are defined in Appendices 1 and 2.

The best model produced by the stepwise procedure using logtransformed sedimentary diatom concentration data showed an $\mathbf{R}^{2}=$ 0.422 , that was less robust than the model based on untransformed data.

The stepwise procedure was applied to annual diatom accumulation rates for 11 diatom taxonomic groups (Appendix 3.6). The procedure was also used for log-transformed accumulation rate data of these taxa. The best model included 3 diatom taxonomic groups and showed an $\mathrm{R}^{2}=0.415(\mathrm{p}=0.006)$. This model bore a stronger relationship with $\operatorname{TSI}(\mathrm{AVG})\left(\mathrm{R}^{2}=0.480, \mathrm{p}<0.001\right)$, and was therefore significantly confounded by this trophic state variable.

\section{Floating-Leaved Biomass}

Stepwise multiple regression was performed on sedimentary concentration and log-transformed sedimentary concentration of 
valves of 9 diatom taxonomic groups (Appendix 3.7) that were correlated with floating-leaved biomass in the cluster analysis procedure. All models that resulted from these stepwise attempts demonstrated random errors. Stepwise regression was also performed on the 7 diatom taxa in the annual-accumulation rate cluster analysis that were correlated with floating-leaved biomass. The best model, as indicated by the $\mathrm{Cp}$ statistic, included a single diatom taxon, and this model explained only $28.7 \%$ of the variance in floating-leaved biomass.

Better results were obtained by stepwise regression of 12 diatom taxonomic groups (Appendix 3.9) that were selected from plots of percentage data for diatom taxa versus floating-leaved biomass. The best model obtained was the following:

$$
\begin{aligned}
\text { FLOATING } & =5.105-3.455 \log 10(\text { ACHS })-2.493 \log 10(\text { CYMMUEL }) \\
& +0.264(\text { CYSTEPDU })-0.281(\text { S-NAVS })-3.297 \log 10(\mathrm{~S}- \\
& \text { NITZS) } \\
\mathrm{R}^{2}=0.866, \mathrm{p} & <0.001, \mathrm{n}=22, \text { adj. } \mathrm{R}^{2}=0.825
\end{aligned}
$$

where FLOATING = floating-leaved biomass in $\mathrm{kg}$ wet mass $\mathrm{m}^{-2}$ ACHS = ACHEX + ACHLIN + ACHLINCU + ACHMIN S-NAVS $=$ NAVGOT + NAVLAN + S-NAVPU + S-NAVRA + NAVSUBTS

NITZS $=$ NITZAM + NITZCAP + NITZFRUS.

The values for all taxonomic groups, whose acronyms are defined in Appendices 1 and 2, are expressed as a percentage of the diatom assemblages. This model appeared to have a significant relationship with submerged biomass $\left(R^{2}=0.502, p=0.034\right)$. Partial correlation coefficients showed that floating-leaved biomass was significantly correlated with the model $(\mathrm{r}=0.882, \mathrm{p}<0.001, \mathrm{n}=22)$ when the 
effect of submerged biomass was held constant. The model was not significantly correlated with submerged biomass $(\mathrm{r}=0.431, \mathrm{p}=$ $0.051, \mathrm{n}=22$ ), however, when the effect of floating-leaved biomass was held constant. This indicates that the above model predicting floating-leaved biomass is not confounded by the variable submerged biomass. The correlation coefficient between submerged biomass and the model, however, failed to be significant at the $\alpha=$ 0.05 level of significance by a marginal amount, and the model may prove to be confounded in certain applications.

\section{Submerged Biomass}

Stepwise multiple regression was performed on percentage data for 20 diatom taxonomic groups (Appendix 3.10) to predict submerged macrophyte biomass. Cp statistic values indicated that the best model contained 11 diatom taxon variables and explained $91.6 \%$ of the variance in submerged biomass $(\mathrm{p}<0.001, \mathrm{n}=22)$. The adjusted $\mathrm{R}^{2}$ for the model was 0.824 . This model, however, also explained $86.9 \%$ of the variance in floating-leaved biomass $(\mathrm{p}=$ $0.004, \mathrm{n}=22$ ) and seems to be confounded by that variable. The partial correlation coefficient between the model and submerged biomass was significant $(r=0.960, p<0.001)$ when the effect of floating-leaved biomass was held constant. The partial correlation coefficient between the model and floating-leaved biomass $(r=$ $0.938, \mathrm{p}<0.001$ ) was also significant when the effect of submerged biomass was held constant. The model to predict submerged biomass, therefore, is not a useful predictive model because it is significantly confounded by floating-leaved biomass. 


\section{$\underline{\text { Sum of Floating and Submerged Biomass }}$}

Because submerged macrophyte biomass could not be separated from floating-leaved biomass in predictive models, an attempt was made to combine these macrophyte variables in a single predictive model. Sixteen diatom taxonomic groups (Appendix 3.11) were selected that appeared to show response to both of these macrophyte variables. The stepwise multiple regression procedure was applied to these groups and it produced the following best model:

$$
\begin{aligned}
\text { FLOAT-SUB }= & 13.292-0.384(\mathrm{~S}-\mathrm{ACH})-1.159(\mathrm{~S}-\mathrm{AULA})- \\
& 23.126(\text { EUNPEC })+0.921(\mathrm{~S}-\mathrm{FRUSRH})-0.912(\mathrm{~S}- \\
& \text { NAVS })+7.115(\mathrm{~S}-\mathrm{STAU})+2.492(\text { EUNVAN }) \\
\mathrm{R}^{2}=0.592, \mathrm{p}= & 0.042, \mathrm{n}=22
\end{aligned}
$$

in which FLOAT-SUB = sum of floating-leaved and submerged macrophyte biomass in $\mathrm{kg}$ wet mass $\mathrm{m}^{-2}$. Acronyms for the taxonomic groups are defined in Appendices 1 and 2. The adjusted $\mathrm{R}^{2}$ for this model was 0.389 .

\section{Emergent Biomass}

The stepwise multiple regression procedure was performed on percentage data of 17 diatom taxonomic groups (Appendix 3.12) to predict emergent biomass. $\mathrm{Cp}$ values of all models with significant $\mathrm{R}^{2}$ values were much less than the $p$ values, which indicated that these models were subject to substantial random error.

\section{Results of Canonical Correspondence Analysis}

The canonical correspondence analysis option of CANOCO (ter Braak 1987) produced eigenvectors (Table 9) ordinating the 47 
Table 9. Eigenvectors for percentage data of 47 diatom taxonomic groups in CANOCO Axis1 constrained by percent-volume infestation. Eigenvectors are presented in descending order. Taxonomic acronyms are defined in Appendix 2.

\begin{tabular}{|c|c|c|c|}
\hline $\begin{array}{l}\text { Taxonomic } \\
\text { group }\end{array}$ & Eigenvector & $\begin{array}{l}\text { Taxonomic } \\
\text { group }\end{array}$ & Eigenvector \\
\hline S-GOMA & 1.78 & AULAAM & -0.40 \\
\hline S-STAU & 1.34 & ACTPUNC & -0.44 \\
\hline S-NAVPU & 1.32 & NAVCUS & -0.45 \\
\hline FRAGPIN & 1.20 & NITZAM & -0.52 \\
\hline S-FRAGCO & 1.14 & CYCPSEUD & -0.60 \\
\hline S-EUN & 1.00 & NITZCAP & -0.61 \\
\hline S-ANOM & 0.77 & S-AULAGR & -0.70 \\
\hline S-NAVSEM & 0.54 & AULAISL & -0.76 \\
\hline S-CYM & 0.50 & NAVSUBT & -0.76 \\
\hline TABFEN & 0.45 & S-SUR & -0.81 \\
\hline NITZFRUS & 0.43 & AULAITAL & -0.85 \\
\hline S-EP & 0.31 & SYNDEL & -0.90 \\
\hline S-ACH & 0.10 & AULADIS & -0.96 \\
\hline CYCSTEL & 0.06 & NAVCONF & -0.96 \\
\hline TABFLOC & -0.02 & CYSTEPDU & -0.99 \\
\hline S-SYNRUM & -0.02 & CALSPA & -1.04 \\
\hline S-NAVRA & -0.06 & SYNFILEX & -1.10 \\
\hline NITZFONT & -0.08 & S-AST & -1.55 \\
\hline CYCMEN & -0.10 & FRAGBREV & -1.55 \\
\hline NAVGOT & -0.10 & & \\
\hline FRAGCROT & -0.11 & & \\
\hline COCPLACL & -0.21 & & \\
\hline S-FRUSRH & -0.21 & & \\
\hline NAVLAN & -0.23 & & \\
\hline S-NEI & -0.26 & & \\
\hline CYCSTELO & -0.27 & & \\
\hline S-PIN & -0.32 & & \\
\hline NITZPAL & -0.35 & & \\
\hline
\end{tabular}


diatom taxonomic groups into an axis constrained by percent-volume infestation. When axis scores for the 29 survey lakes were regressed with percent-volume infestation values using the SAS GLM procedure (SAS Institute, Inc. 1985), the following predictive equation was obtained:

$$
\begin{aligned}
& \text { percent-volume infestation }=33.8+0.7(\text { Axis } 1) \\
& \mathrm{r}^{2}=0.600, \mathrm{p}<0.001, \mathrm{n}=29
\end{aligned}
$$

where Axis 1 is the sum of products of eigenvectors and percentages of the 47 diatom taxonomic groups.

When canonical correspondence was invoked to produce eigenvectors ordinating the 47 diatom taxonomic groups into an axis constrained by percent-area coverage, CANOCO returned eigenvectors ordinating 45 of the taxonomic groups (Table 10). Tabellaria fenestrata and $T$. floccolosa may have been eliminated by CANOCO in this ordination because of under-representation. Axis scores for the 22 survey lakes with percent-area coverage values were regressed with percent-area coverage using the SAS GLM procedure (SAS Institute, Inc. 1985). The resulting equation was:

$$
\begin{aligned}
& \text { percent-area coverage }=53.6-0.5(\text { Axis } 1) \\
& \mathrm{r}^{2}=0.447, \mathrm{p}<0.001, \mathrm{n}=22
\end{aligned}
$$

where Axis 1 is the sum of products of the percentages and eigenvectors of the 45 diatom taxonomic groups shown in Table 10.

\section{A New Predictive Model for Water-Column Total P}

Because inferences from Whitmore's (1989) TSI(TP) predictive model cannot detransformed to yield total P values for WCP (Canfield et al. 1983a) estimates, a new model is presented here using the 
Table 10. Eigenvectors for percentage data of 45 diatom taxonomic groups in CANOCO Axis1 constrained by percent-area coverage. Eigenvectors are presented in descending order. Taxonomic acronyms are defined in Appendix 2.

\begin{tabular}{|c|c|c|c|}
\hline $\begin{array}{l}\text { Taxonomic } \\
\text { group }\end{array}$ & Eigenvector & $\begin{array}{l}\text { Taxonomic } \\
\text { group }\end{array}$ & Eigenvector \\
\hline FRAGBREV & 2.11 & S-NEI & -0.17 \\
\hline FRAGCROT & 1.49 & S-ACH & -0.18 \\
\hline NAVCONF & 1.47 & S-PIN & -0.19 \\
\hline S-NAVPU & 1.26 & S-STAU & -0.25 \\
\hline CYCPSEUD & 1.17 & S-FRAGCO & -0.28 \\
\hline CYSTEPDU & 1.16 & NAVSUBT & -0.30 \\
\hline NITZPAL & 1.15 & CYCSTELO & -0.31 \\
\hline CALSPA & 1.06 & FRAGPIN & -0.35 \\
\hline SYNFILEX & 1.01 & S-SUR & -0.48 \\
\hline AULAAM & 1.00 & S-FRUSRH & -0.71 \\
\hline NITZFONT & 0.88 & S-ANOM & -0.73 \\
\hline S-AULAGR & 0.86 & S-GOMA & -0.84 \\
\hline AULAITAL & 0.86 & S-EP & -0.86 \\
\hline S-AST & 0.85 & S-EUN & -1.08 \\
\hline COCPLACL & 0.84 & S-CYM & -1.18 \\
\hline NITZCAP & 0.59 & ACTPUNC & -1.29 \\
\hline NAVCUS & 0.55 & & \\
\hline CYCMEN & 0.53 & & \\
\hline NITZAM & 0.53 & & \\
\hline AULAISL & 0.43 & & \\
\hline S-NAVRA & 0.42 & & \\
\hline NAVGOT & 0.25 & & \\
\hline NAVLAN & 0.21 & & \\
\hline S-SYNRUM & 0.19 & & \\
\hline S-NAVSEM & 0.18 & & \\
\hline CYCSTEL & -0.07 & & \\
\hline NITZFRUS & -0.10 & & \\
\hline SYNDEL & -0.15 & & \\
\hline AULADIS & -0.16 & & \\
\hline
\end{tabular}




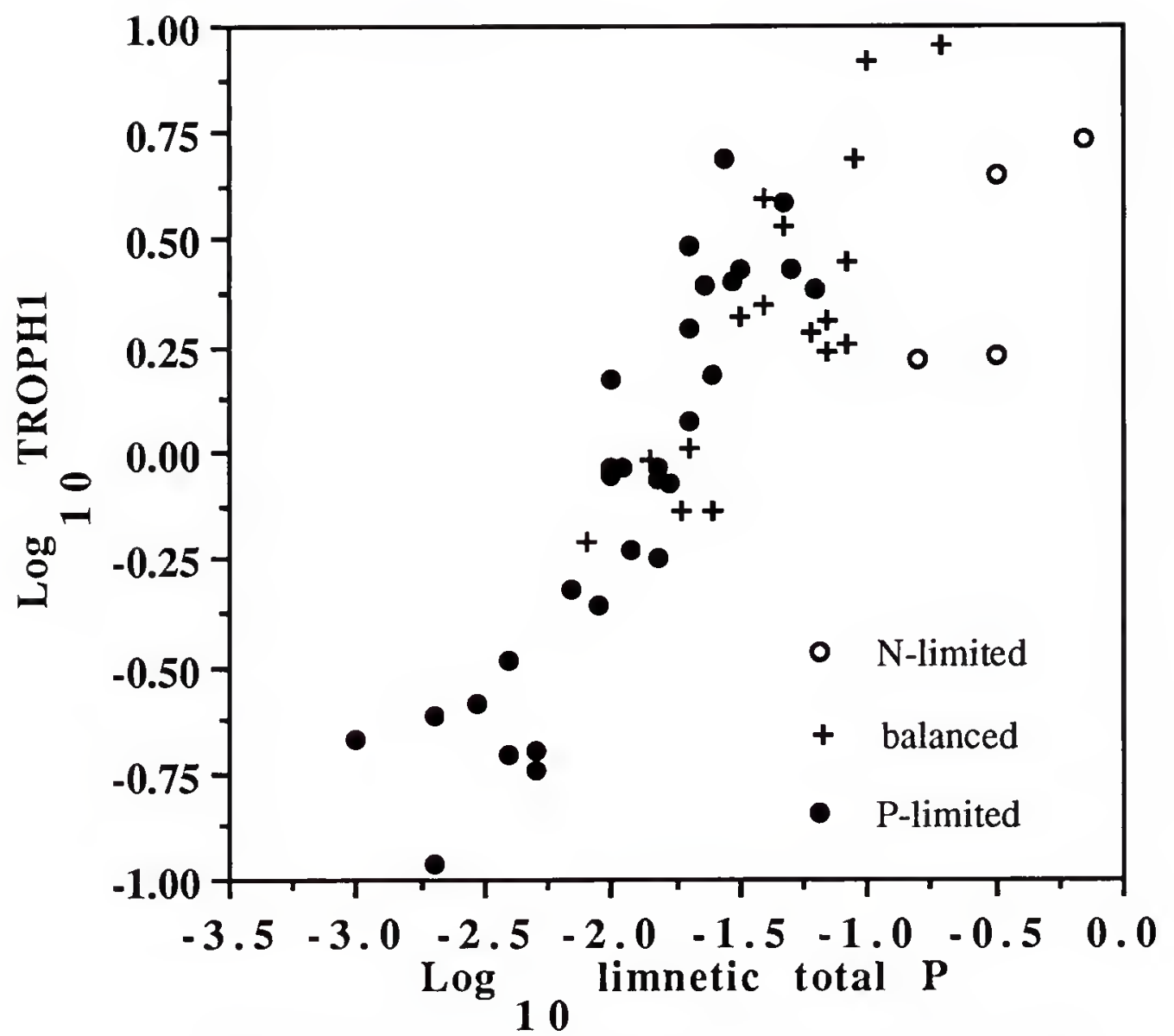

Figure 9. Log-transformed total $P$ versus log-transformed TROPH1 diatom index for 51 lakes. 
TROPH 1 diatom index (Whitmore 1989) to predict log-transformed water-column total P. Figure 9 shows a plot of log-transformed water-column total $\mathrm{P}$ versus the TROPH1 diatom index for 51 Florida lakes. The four nitrogen-limited lakes shown demonstrated anomalously low diatom index values for their total $P$ values, and were removed from the regression data set. The resulting predictive model was:

$$
\begin{aligned}
& \log 10(\text { total } \mathrm{P})=-1.795+0.973(\log 10(\text { TROPH } 1)) \\
& \mathrm{r}^{2}=0.807, \mathrm{p}<0.001, \mathrm{n}=47 .
\end{aligned}
$$

\section{Assessing Confoundedness in the Water-Column Total P Predictive} Model

The significant negative correlation coefficient that was observed between log-transformed total $\mathrm{P}$ and percent-area coverage (Table 11) confirmed the inverse relationship previously observed (Canfield et al. 1984) between macrophyte presence and water-column nutrient concentrations. The correlation coefficient between the logtransformed TROPH 1 diatom index and percent-area coverage, however, was not significant (Table 11). The model for predicting water-column total $\mathrm{P}$ from the TROPH 1 diatom index is not confounded by the macrophyte variable percent-area coverage. 
Table 11. Correlation coefficients between TSI(TP), percent area coverage and the log-transformed diatom index TROPH 1. $*=\mathrm{p}<0.05$.

\section{correlation coefficient}

prob. $>$ I r l under Ho: rho $=0$

sample size

\begin{tabular}{lcc}
\hline & $\begin{array}{c}\text { Water-column } \\
\text { total }\end{array}$ & $\begin{array}{c}\text { Percent- } \\
\text { area } \\
\text { coverage }\end{array}$ \\
& $P$ & \\
$\log ($ TROPH 1) & $* 0.838$ & -0.359 \\
& $<0.001$ & 0.101 \\
& 29 & 22 \\
Percent- & & \\
area & $* 0.537$ & \\
coverage & 0.010 & \\
& 22 &
\end{tabular}




\section{CHAPTER 4}

\section{DISCUSSION}

\section{Dominant Environmental Variables and Scale of Analysis}

The purpose of this study was to identify diatom taxa that are indicators of macrophyte presence in lakes. Despite an appropriate sampling design, macrophytes were not found to be a primary determinant of diatom assemblages. A trophic-state/pH/specificconductance environmental gradient was the principal influence on the diatom communities.

I sampled lakes along a wide gradient of macrophyte abundance in order to develop predictive models with broad application for inferring historical macrophyte standing crop, and by necessity I transgressed the trophic-state gradient that is present among Florida lakes. A negative correlation exists between macrophyte abundance and water-column Chl a (Canfield et al. 1984) in Florida lakes. I also observed a negative correlation between percent-area coverage of macrophytes and water-column total $P$ in the present study. Lakes that were low in percent-area coverage $(<10 \%)$ were high in watercolumn nutrients, whereas several lakes that were high in percentarea coverage $(>80 \%)$ were low in water-column nutrients.

$\mathrm{pH}$, trophic state and specific conductance were mutually correlated in this study as in other studies of Florida lakes (Canfield 
1981, Brenner et al. 1990, Whitmore 1989). The majority of Florida lakes are soft-water, acidic and low in alkalinity (Brenner et al. 1990). Nevertheless, many lakes on phosphatic sands or carbonaterich bedrock are naturally high in productivity and dissolved solutes (Canfield 1981). Because the present survey spanned a wide range of limnological conditions, trophic state, $\mathrm{pH}$ and specific conductance formed a dominant environmental gradient that emerged as the principal determinant of diatom community composition.

Jackson and Charles (1988) observed the effect of a similar environmental gradient on macrophyte distribution in the Adirondack lakes of New York. They found that alkalinity, $\mathrm{pH}$ and ionic composition were interrelated factors that determined the distribution and species composition of aquatic vegetation. Jackson and Charles stated:

We conclude that the chemical gradient underlying compositional variation among our Adirondack softwater sites is the tail end of a broad $\mathrm{pH}$ complex-gradient that extends to highly alkaline waters. At the scale of environmental variation observed in Adirondack lakes, the main factors associated with vegetation variation are $\mathrm{pH}$, alkalinity, $\mathrm{Ca}, \mathrm{Mg}$, and perhaps $\mathrm{Al}$. In regions where the gradient is broader, or at least where the hardwater portion is represented, conductivity and trophic status become more important (Jackson and Charles 1988, p. 1456-1457).

Because Florida lakes exhibit a wide scale of variation from softwater to hardwater conditions, the resulting chemical gradient determined diatom community composition in the same manner that the chemical gradient in Adirondacks lakes determined macrophyte composition. The fact that diatom community composition was 
determined mostly by trophic-state, $\mathrm{pH}$, and specific conductance rather than by macrophyte presence was thus the result of the scale of analysis as discussed by Duarte and Kalff (1990). The dominant effects of trophic state and $\mathrm{pH}$ may have overridden differences in community structure that resulted from the influence of macrophytes. In addition, most lakes in the survey were shallow (mean depth $<3.0 \mathrm{~m}$ ), and periphytic diatom communities may be less specific about substrate types than previous qualitative studies (e.g. Round 1956) have suggested.

Future studies might minimize error variance in macrophyte predictive models by focusing on a calibration set of lakes that covers a narrower range of trophic state and $\mathrm{pH}$. This approach would sacrifice generality but improve the precision of prediction for lakes with a limited range of macrophyte standing crop. Duarte and Kalff warn, however, that "There is no reason to expect that patterns found at any one scale are transferable to other scales" (Duarte and Kalff 1990 , p. 362). A problem of scale arises when any predictive model derived from a set of limnologically diverse lakes is applied historically to a single lake that has remained comparatively constant in character over time. Confidence intervals are inappropriately large for historical predictions because fewer factors affect the error variance within a single basin than within a calibration data set.

\section{Negative Relationship Between Chl. a and Macrophytes}

Lower water-column total $\mathrm{P}$ values may occur in lakes with high macrophyte standing crop for the following possible reasons invoked by Canfield et al. (1984) to explain macrophytic influence on Chl a: 
1) The phytoplankton community competes with macrophytes, especially floating macrophytes (e.g. Eichhornia), and their associated epiphyton for dissolved nutrients in the water column. High macrophyte standing crop could therefore depress water-column nutrient concentrations;

2) Macrophytes minimize wind mixing and resuspension of nutrients from bottom sediments leading to a reduction in nutrient cycling.

Other possible explanations for the negative correlation include:

1) Rooted macrophytes may proliferate in lakes that are naturally low in water-column total $P$ concentrations because they don't depend on the water for their nutrient supply. Most of the $P$ they utilize is derived from the sediments (Carignan and Kalff 1980);

2) When water-column nutrient concentrations are high, phytoplankton and epiphyton standing crop increases and may limit submerged macrophytes by shading (Sand-Jensen and Sondergaard 1981).

\section{Response of Periphyton to Water-Column Nutrients}

TSI variables demonstrated positive correlations with the proportion of planktonic diatoms, and negative correlations with the proportion of periphytic diatoms in the survey lakes. This suggests that planktonic diatom populations assume greater importance relative to periphyton populations in lakes that are higher in trophic state. The positive correlations between water-column total $\mathrm{P}$ and the concentrations and log-transformed accumulation rates of periphytic diatoms, however, show that even if plankton assume greater inportance at higher water-column nutrient concentrations, periphyton production also increases with increasing trophic state. 
A positive response of periphyton biomass to higher watercolumn nutrients has been demonstrated in previous experimental studies and lake surveys (Stockner and Armstrong 1971, Ennis 1975, Shortreed et al. 1984). Sand-Jensen and Sondergaard (1981) came to the unusual conclusion that epiphyton biomass increased more than phytoplankton biomass in response to increased nutrient loading. Other studies, which appear less conclusive, have shown that periphytic biomass may be unaffected or even decline with increasing water-column P concentrations. Cattaneo (1987) concluded that periphytic biomass showed a low and variable response to water-column total $\mathrm{P}$ in his survey of 10 Canadian lakes, but admitted that wave intensity may have altered periphytic biomass on the surface of the large stones in shallow water where he obtained his samples. Hansson (1988) found a weak, negative correlation between log-transformed periphytic algal biomass, as assessed from colonization rates on nylon net, and log-transformed total $\mathrm{P}$ in 20 Swedish lakes.

Hansson speculated that in lakes of higher trophic state, plankton may limit periphyton populations to some extent by shading. Hansson noted, however, that cold temperatures in the subalpine lakes of his survey may have affected colonization rates and led to some underestimates of periphyton standing crop.

One study of periphyton and plankton communities in a Florida lake demonstrated a strong negative relationship between the biomass of these groups over a 5-month period (Hodgson et al. 1986). This negative correlation, however, reflected seasonal variation in community dominance within a single, closed system. 
In the present study, subfossil assemblages integrated over several recent years showed a clear positive correlation between periphyton production and trophic state for a limnologically diverse set of Florida lakes. Log-transformed values of planktonic and periphytic diatom concentrations were positively correlated $(\mathrm{r}=$ $0.643, \mathrm{p}<0.001, \mathrm{n}=28$ ), as were log-transformed planktonic and periphytic diatom accumulation rates $(r=0.717, \mathrm{p}<0.001, \mathrm{n}=26)$. A positive response of both periphyton and plankton communities to water-column nutrient concentrations was observed in another study in Florida that examined sedimentary diatom concentrations and accumulation rates along a trophic gradient (Whitmore in press). Although phytoplankton and periphyton may be negatively correlated within a lake (Hodgson et al. 1986), this interpretation is also influenced by the scale of analysis: they are both positively affected by water-column nutrient concentrations when considered over a broad scale of trophic state.

\section{$\underline{\text { Recommended Predictive Models for Macrophyte Variables }}$}

During construction of the predictive models in this study, particular attention was paid to the potential covariant effects nontarget environmental variables might have on the predictive models. Equation 3.1, for example, which predicted floating-leaved biomass, was shown to be confounded by $\mathrm{pH}$. Equation 3.3 was a multivariate regression equation predicting percent-area coverage that was confounded by TSI(AVG). In general, I do not recommend historical application of diatom predictive models that might relate to more 
than one dependent variable because of the risk of error caused by unassessed changes in the covariable.

None of the multiple regression methods produced a useful model for predicting emergent biomass. All stepwise multiple regression models for emergent biomass were subject to random error. The reason that diatom taxa related so poorly to emergent vegetation might be that the stems of emergent vegetation do not provide the large surface areas for periphyton attachment that submerged and floating-leaved macrophytes provide. Surface area has been shown to be a primary factor influencing epiphytic biomass (Cattaneo and Kalff 1980). Plants with many small or finelydissected leaves and more lateral growth patterns such as Hydrilla, Valisneria and Myriophyllum would, therefore, demonstrate clearer relationships with periphytic biomass than would emergent macrophytes having vertical growth forms. Hoyer and Canfield (1986), in addition, have shown that the mean surface area to biomass ratio of submerged plants is higher than for emergent plants, which permits a greater biomass of periphyton to be supported on submerged plants than on an equal weight of emergent plants.

The best model for predicting percent-volume infestation was equation 3.7 that was derived by canonical correspondence analysis and explained $60 \%$ of the variance in that macrophyte variable. Equation 3.2, a mutlivariate equation that was based on three diatom taxa, also explained $52 \%$ of the variance in percent volume infestation. Percent-area coverage is best predicted with equation 3.4 that was based on 4 diatom taxa and explained approximately 
$61 \%$ of the variance in areal macrophyte coverage. Another good model for predicting percent-area coverage was the canonical correspondence equation 3.8 that explained $45 \%$ of the variance in this variable. I prefer the use of the canonical correspondence analysis models over the multiple regression models because many environmental factors may affect species' distributions (Patrick 1973), and interpretations based on a few species are less likely to be reliable. None of these 4 models was statistically confounded by covariant environmental or macrophyte variables.

Macrophyte predictive models should prove useful for assessing historical patterns in macrophyte standing crop that resulted from changes in nutrient loading (Purohit and Singh 1985). Historical water level changes might also be inferred from macrophyte predictive models because macrophyte standing crop will increase when lower water levels permit a lakeward expansion of rooted macrophytes (Landers 1982), or when higher water levels permit macrophyte colonization of a shallow littoral shelf (Anderson 1990).

Floating-leaved biomass is best predicted using equation 3.5 that explains approximately $87 \%$ of the variance in this variable using 5 diatom taxonomic groups. Partial correlations showed that the floating-leaved biomass model was marginally unconfounded by submerged biomass. None of the models for predicting submerged biomass was useful, however, because of statistical confoundedness with floating-leaved biomass. Perhaps this confoundedness occurs because periphytic taxa are not specific in their attachment sites with respect to floating versus submerged vegetation, and planktonic taxa are negatively affected to an equal degree by both types of 
vegetation. Combined floating and submerged biomass can be assessed historically using equation 3.6. Despite an $R^{2}$ of approximately 0.60 , the adjusted $R^{2}$ indicates that this model, which is based on 7 diatom taxonomic groups, explains about $39 \%$ of the variance in floating and submerged biomass.

Applying Predictive Models to Obtain Historical TSI Estimates

The predictive models shown above can be used to determine the historical trophic state classification of lakes taking the nutrients in macrophyte biomass into account (Canfield et al. 1983a). The floating-leaved and submerged biomass model (equation 3.6) can be used in conjunction with equations 3.4 or 3.8 , predicting percentarea coverage, in order to estimate the total submerged and floatingleaved biomass for historical samples. Total floating-leaved and submerged biomass (TFSB) is calculated as:

$\mathrm{TFSB}=\mathrm{SA} \times(\mathrm{PACi} / 100) \times \mathrm{Bi}$

where $\mathrm{SA}=$ lake surface area $\left(\mathrm{m}^{2}\right)$

$\mathrm{PACi}=$ inferred percent-area coverage

$\mathrm{Bi}=$ inferred floating-leaved and submerged biomass $\left(\mathrm{kg} \mathrm{m}^{-2}\right)$.

Canfield et al. (1983a) report different percent $\mathrm{P}$ values for the dry weight of individual macrophyte taxa, though variation is shown between lakes in those values. It is difficult to calculate accurately the amount of $\mathrm{P}$ contained in the inferred total biomass because the biomass of individual macrophyte taxa cannot be determined from the diatom predictive models, and inferences are for wet weight of macrophyte biomass. If an overall mean percent $P$ value $(0.234 \%)$ is 
used, however, and we assume that plant water content is $90 \%$ of fresh weight (Canfield and Duarte 1988), it is possible to multiply mean percent $\mathrm{P}$ by the total dry weight of floating-leaved and submerged biomass to obtain an estimate of the $\mathrm{kg}$ of $\mathrm{P}$ that would be released to the water column assuming $100 \%$ decomposition of macrophyte biomass. Dividing this mass of $\mathrm{P}$ by the volume of the lake produces a water-column $\mathrm{P}$ concentration that represents the macrophyte component of trophic state. This $\mathrm{P}$ concentration can be added to water-column total $P$ inferences obtained using equation 3.9 to estimate the potential total $\mathrm{P}$ content of the water column (WCP, Canfield et al. 1983a). Historical WCP estimates should take macrophyte nutrients into account and thereby provide a more complete assessment of historical trophic state than inferences based solely on water-column total $\mathrm{P}$.

Whitmore's (1989) model for predicting TSI(TP) from the TROPH 1 diatom index is useful for historically assessing changes in lake trophic state, but inferred TSI(TP) values cannot be detransformed to yield the water-column total $\mathrm{P}$ inferences necessary to calculate WCP. Two separate equations are used to derive TSI(TP) from total $P$ values, depending on whether a given lake is P-limited or nutrientbalanced (Huber et al. 1982). In historical applications, a lake may have undergone changes in nutrient limitation over time, especially if the lake received agricultural runoff, or if sewage effluent had been directed into the lake. It would be difficult, therefore, to select the appropriate equation to detransform an historic TSI(TP) inference. Equation 3.9 in the present study will provide inferences of log-transformed water-column total $\mathrm{P}$, however, and these 
inferences can be detransformed to provide the necessary watercolumn total $\mathrm{P}$ values for WCP estimates.

Because of the long growing season and mild climate in Florida, the annual dieback of macrophytes and nutrient release is not likely to occur to the degree in Florida that it does in winter in coldtemperate areas. Death and decomposition of macrophytes in warmtemperate and subtropical Florida lakes are less synchronized and dramatic than in colder regions. The nutrients present in macrophytes are derived from the sediment, and their release to the water column, however slow, does represent a source of nutrient loading to lakes. Although nutrients in macrophytes of Florida lakes may be less apt to appear in the water column in a seasonal pulse, macrophytes represent a substantial component of primary production and their nutrients are as germane to the concept of trophic state as the water-column nutrients contained in phytoplankton. 


\section{APPENDIX 1}

\section{SPECIES NAMES, ACRONYMS AND \\ LIFE-FORM CLASSIFICATIONS}

Key to Appendix

$$
\begin{aligned}
& \text { Life-form classifications } \\
& \begin{aligned}
\mathrm{e} & =\text { euplanktonic } \\
\mathrm{t} & =\text { tychoplanktonic } \\
\mathrm{p} & =\text { periphytic } \\
\mathrm{u} & =\text { unknown } \\
* & =\text { assumed based on valve morphology }
\end{aligned}
\end{aligned}
$$

Species name

Life-

Acronym form

class.

Achnanthes biasolettiana (?Kütz.) Grun.

Achnanthes exigua Grun. var. exigua

Achnanthes exigua var. constricta (Grun.) Hust.

Achnanthes exigua var. heterovalva Krasske

Achnanthes kryophila Pet.

Achnanthes lanceolata (Bréb.) Grun. var. lanceolata

Achnanthes lanceolata var. dubia Grun.

Achnanthes linearis (W. Sm.) Grun. var. linearis

Achnanthes linearis f. curta H.L. Sm.

Achnanthes microcephala (Kütz.) Grun. var.

microcephala

Achnanthes minutissima Kütz. var. minutissima

Achnanthes pinnata Hust. var. pinnata

Achnanthes sp.

Actinella punctata Lewis var. punctata
ACHBIAS u

ACHEX $p$

ACHEXCO $p$

ACHEXHE $p$

ACHKRY u

ACHLAN $p$

ACHLANDU $\mathrm{p}$

ACHLIN p*

ACHLINCU $p^{*}$

ACHMIC $\quad p^{*}$

ACHMIN $p$

ACHPIN u

ACHSP u

ACHPUNC $p^{*}$ 
Amphora ovalis Kutz. var. ovalis

Amphora ovalis var. affinis (Kütz.) V.H. ex Det.

Amphora ovalis var. pediculus (Kütz.) V.H. ex Det.

Anomeoneis serians (Bréb. ex Kütz.) Cl. var. serians

Anomeoneis serians var. acuta Hust.

Anomeoneis serians var. apiculata Boyer

Anomeoneis serians var. brachysira (Bréb.

ex Kütz.) Hust.

Anomeoneis vitrea (Grun.) Ross var. vitrea

Asterionella formosa Hass. var. formosa

Asterionella ralfsii W. Sm. var. ralfsii

Aulacoseira ambigua (Grun.) Sim. var. ambigua

Aulacoseira distans (Ehr.) Sim. var. distans

Aulacoseira granulata (Ehr.) Sim. var. granulata

Aulacoseira granulata (Ehr.) Sim. var. angustissima O. Müll.

Aulacoseira islandica (O. Müll.) Sim. var. islandica

Aulacoseira italica (Ehr.) Sim. var. italica

Aulacoseira sp.

Caloneis bacillum (Grun.) Cl. var bacillum

Caloneis latiuscula (Kütz.) $\mathrm{Cl}$.

Caloneis sp. A

Caloneis ventricosa (Ehr.) Meist. var. ventricosa

Capartogramma crucicula (Grun. ex Cl.) Ross var. crucicula

Cocconeis placentula Ehr. var. placentula

Cocconeis placentula var. lineata (Ehr.) V.H.

Cocconeis sp.

Cyclostephanos dubius (Fricke) Round

Cyclotella meneghiniana Kütz. var. meneghiniana

Cyclotella pseudostelligera Hust. var. pseudostelligera

Cyclotella radiosa (Grun.) Lemmerman

Cyclotella stelligeroides Hust.

Cyclotella sp.

Cyclotella sp. A

Cyclotella stelligera $\mathrm{Cl}$. u. Grun. var. stelligera

Cymbella angustata (W.Sm.) Cl. var. angustata

Cymbella lunata W. Sm. var. lunata

Cymbella microcephala Grun. var. microcephala

Cymbella minuta Hilse ex Rabh. var. minuta

Cymbella minuta var. silesiaca (Bleisch ex Rabh.)

Reim.

AMPOV $p$

AMPOVAF $p$

AMPOVPED $\mathrm{p}$

ANOMSE u

ANOMSEAC $p$

ANOMSEAP $p$

ANOMSERB $p$

ANOMVIT $p$

ASTFOR e

ASTRAL e

AULAAM e

AULADIS $p$

AULAGR e

AULAGRAN e

AULAISL e

AULAITAL $\mathrm{t}-\mathrm{p}$

AULASP $u$

CALSP $\quad p$

CALLAT $p$

CALSPA p*

CALVEN $p$

CAPCRU u

COCPLAC $\mathrm{p}$

COCPLACL $p$

COCSP $p$

CYSTEPDU $\mathrm{e}$

CYCMEN e-p

CYCPSEUD $t *$

CYCRAD e

CYCSTELO $\mathrm{t}-\mathrm{p}$

CYCSP

u

CYCSPA u

CYCSTEL $t-p$

CYMANG $p$

CYMLUN $\mathrm{p}^{*}$

CYMMIC $\quad p$

CYMMIN p

CYMMINSI p 
Cymbella muelleri Hust. var. muelleri

Cymbella sp.

Diploneis elliptica (Kütz.) Cl. var. elliptica

Diploneis sp.

Epithemia adnata (Kütz.) Bréb. var. adnata

Epithemia argus var. alpestris Grun.

Epithemia sp.

Eunotia bidentula W. Sm. var. bidentula

Eunotia carolina Patr. var. carolina

Eunotia curvata (Kütz.) Largerst. var. curvata

Eunotia diodon Ehr. var. diodon

Eunotia flexuosa Bréb. ex Kütz. var. flexuosa

Eunotia formica Ehr. var. formica

Eunotia incisa W. Sm. ex Greg. var. incisa

Eunotia indica Grun. var. indica

Eunotia luna Enr. var. luna

Eunotia maior (W. Sm.) Rabh. var. maior

Eunotia monodon Ehr. var. monodon

Eunotia naegeli Migula var. naegeli

Eunotia pectinalis (O.F. Müll.?) Rabh. var. pectinalis

Eunotia pectinalis var. minor (Kütz.) Rabh.

Eunotia sp.

Eunotia vanheurckii Patr. var. vanheurckii

Eunotia vanheurckii var. intermedia (Krasske ex.

Hust.) Patr.

Fragilaria brevistriata Grun. var. brevistriata

Fragilaria brevistriata var. inflata (Pant.) Hust.

Fragilaria construens (Ehr.) Grun. var. construens

Fragilaria construens var. pumila Grun.

Fragilaria construens var. venter (Ehr.) Grun.

Fragilaria crotonensis Kitton. var. crotonensis

Fragilaria pinnata Ehr. var. pinnata

Fragilaria virescens Ralfs. var. virescens

Frustulia rhomboides (Ehr.) DeT. var. rhomboides

Frustulia rhomboides var. capitata (A. Mayer) Patr.

Frustulia rhomboides var. saxonica (Rabh.) DeT.

Gomphonema affine Kütz. var. affine

Gomphonema gracile Ehr. var. gracile

Gomphonema grunowii Patr. var. grunowii

Gomphonema intricatum Kütz. var. intricatum

Gomphonema parvulum (Kütz.) var. parvulum

Gomphonema parvulum var. lanceolata Grun.

Gomphonema sp.

$\begin{array}{ll}\text { CYMMUEL } & \mathrm{p} \\ \text { CYMSP } & \mathrm{p} \\ \text { DIPEL } & \mathrm{p} \\ \text { DIPSP } & \mathrm{p} \\ \text { EPAD } & \mathrm{p} \\ \text { EPARGAL } & \mathrm{p} * \\ \text { EPSP } & \mathrm{p} \\ \text { EUNBIDT } & \mathrm{u} \\ \text { EUNCARO } & \mathrm{u} \\ \text { EUNCUR } & \mathrm{t}-\mathrm{p} \\ \text { EUNDIOD } & \mathrm{p} \\ \text { EUNFLEX } & \mathrm{p} \\ \text { EUNFOR } & \mathrm{p} \\ \text { EUNINC } & \mathrm{p} \\ \text { EUNIND } & \mathrm{p} \\ \text { EUNLUNA } & \mathrm{u} \\ \text { EUNMAI } & \mathrm{p} \\ \text { EUNMON } & \mathrm{p} \\ \text { EUNNAE } & \mathrm{p} \\ \text { EUNPEC } & \mathrm{p} \\ \text { EUNPECM } & \mathrm{p} \\ \text { EUNSP } & \mathrm{p} \\ \text { EUNVAN } & \mathrm{p}\end{array}$

EUNVANIN $\mathrm{p}^{*}$

FRAGBREV $p$

FRAGBRIN $p$

FRAGCON $\mathrm{t}-\mathrm{p}$

FRAGCONP $\mathrm{t}-\mathrm{p}$

FRANCONV $\mathrm{t}-\mathrm{p}$

FRAGCROT $\mathrm{e}$

FRAGPIN $p$

FRAGVIR u

FRUSRH $p$

FRUSRHCA p

FRUSRHSA $\mathrm{p}^{*}$

GOMAAF $p$

GOMAGRAC $\mathrm{t}-\mathrm{p}$

GOMAGRUN $p$

GOMAIN $\mathrm{p}$

GOMAPAR $p$

GOMAPARL $p$

GOMASP $p$ 
Gopmphona truncatum var. turgidum (Ehr.) Patr. Gyrosigma obscurum (W. Sm.) Griff. \& Henfr. var. obscurum

Hantzschia amphioxys (Ehr.) Grun. var. amphioxys Mastogloia smithii var. lacustris Grun.

Navicula accomoda Hust. var. accomoda

Navicula anglica var. subsalsa (Grun.) $\mathrm{Cl}$.

Navicula arvensis Hust. var. arvensis

Navicula confervacea (Kütz.) Grun. var. confervacea Navicula confervacea var. peregrina (W. Sm.) Grun. Navicula cuspidata (Kütz.) Kütz. var. cuspidata Navicula exigua Greg. ex. Grun. var. exigua Navicula exigua var. capitata Patr. Navicula gottlandica Grun. var. gottlandica Navicula halophila (Grun.) Cl. var. halophila Navicula hustedtii Krasske var. hustedtii Navicula kriegeri Krasske Navicula lanceolata (Ag.) Hust. var. lanceolata Navicula minima Grun. var. minima Navicula mutica Kütz. var. mutica Navicula oblonga (Kütz.) var. oblonga Navicula pupula Kütz. var. pupula Navicula pupula var. elliptica Hust. Navicula pupula var. rectangularis (Greg.) Grun. Navicula radiosa Kütz. var. radiosa Navicula radiosa var. parva Wallace Navicula rhyncocephala Kütz. var. rhyncocephala Navicula rhyncocephala var. germainii (Wallace)

\section{Patr.}

Navicula seminuloides Hust.

Navicula seminulum Grun. var. seminulum

Navicula seminulum var. hustedtii Patr.

Navicula seminulum var. intermedia Hust.

Navicula sp.

Navicula sp. F

Navicula subtilissima $\mathrm{Cl}$. var. subtilissima

Navicula tripunctata (O. Müll.) Bory var. tripunctata

Navicula viridula var. linearis Hust.

Neidium affine (Ehr.) Pfitz. var. affine

Neidium affine var. amphirhyncus (Ehr.) $\mathrm{Cl}$.

Neidium affine var. ceylonicum (Skv.) Reim.

Neidium apiculatum Reim. var. apiculatum

Neidium dubium (Ehr.) Cl. var. dubium
GOMATRUT p

GYROOBS u

HANTAMP $p$

MASTSMLA $\mathrm{p}$

NAVACCOM u

NAVANGSU u

NAVARV $\mathrm{p}^{*}$

NAVCONF $p$

NAVCONFP $p$

NAVCUS $p$

NAVEX $p$

NAVEXCA p

NAVGOT p*

NAVHAL u

NAVHUST $p^{*}$

NAVKRIEG u

NAVLAN $p$

NAVMIN $p$

NAVMUT $\mathrm{t}-\mathrm{p}$

NAVOBL $p$

NAVPU $p$

NAVPUEL $p$

NAVPURE $p$

NAVRA $p$

NAVRAPA $p$

NAVRHY p

NAVRHYGE u

NAVSE u

NAVSEM $p^{*}$

NAVSEMHU u

NAVSEMIN $\mathrm{p}^{*}$

NAVSP $\quad p$

NAVSPF u

NAVSUBT $p *$

NAVTRI $p$

NAVVIRL $p$

NEIAF $p$

NEIAFAMP $p$

NEIAFCEY p*

NEIAP $p$

NEIDUB $\mathrm{u}$ 
Neidium floridanum Reim. var. floridanum

Neidium iridis (Ehr.) Cl. var. iridis

Neidium iridis var. amphigomphus (Ehr.) A. Mayer

Neidium iridis var. ampliatum (Ehr.) $\mathrm{Cl}$.

Neidium ladogense var. densestriatum (Østr.) Foged

Neidium sp.

Nitzschia amphibia Grun. var. amphibia

Nitzschia capitellata Hust. var. capitellata

Nitzschia fonticola Grun. var. fonticola

Nitzschia frustulum Kütz. var. frustulum

Nitzschia gracilis Hantz.

Nitzschia Hantzschiana Rabh.

Nitzschia linearis (W. Sm.) var. linearis

Nitzschia obtusa W. Sm. var. obtusa

Nitzschia palea (Kütz.) W. Sm. var. palea

Nitzschia romana Grun.

Nitzschia scalaris (Ehr.) W. Sm.

Nitzschia sigma (Kütz.) W. Sm. var. sigma

Nitzschia sp.

Nitzschia tryblionella var. levidensis (W. Sm.) Grun.

Opephora americana M. Perag. var. americana

Opephora martyi Herib. var. martyi

Pinnularia abaujensis (Pant.) Ross var. abaujensis

Pinnularia abaujensis var. linearis (Hust.) Patr.

Pinnularia abaujensis var. rostrata (Patr.) Patr.

Pinnularia appendiculata (Ag.) $\mathrm{Cl}$. var. appendiculata

Pinnularia biceps Greg. var. biceps

Pinnularia biceps var. petersenii Ross

Pinnularia borealis var. rectangularis Carlson

Pinnularia braunii (Grun.) Cl. var. braunii

Pinnularia braunii var. amphicephala (A. Mayer) Hust.

Pinnularia caudata (Boyer) Patr. var. caudata

Pinnularia dactylus Ehr. var. dactylus

Pinnularia latevittata $\mathrm{Cl}$. var. latevittata

Pinnularia latevittata var. domingensis $\mathrm{Cl}$.

Pinnularia legumen (Ehr.) Ehr. var. legumen

Pinnularia sp.

Pinnularia sp. B

Pinnularia subcapitata Greg. var. subcapitata

Pinnularia subcapitata var. paucistriata (Grun.) $\mathrm{Cl}$.

Pinnularia viridis (Nitz.) Ehr. var. viridis

Pinnularia viridis var. minor $\mathrm{Cl}$.

NIEFL $\quad p$

NEIIR $p$

NEIIRAMH $p$

NEIIRAML $p$

NEILADDE $p$

NEISP

NITZAM $p$

NITZCAP $\mathrm{t}-\mathrm{p}$

NITZFONT $p$

NITZFRUS $e-p$

NITZGRAC u

NITZHANT u

NITZLIN $\mathrm{p}$

NITZOBT u

NITZPAL $t-p$

NITZROM $t^{*}$

NITZSCAL u

NITZSIG p

NITZSP $p$

NITZTRYL $\mathrm{t}-\mathrm{p}$

OPEAM $p$

OPEMAR $p$

PINABA $p$

PINABAL $p$

PINABAR $p$

PINAP $\quad \mathrm{p}^{*}$

PINBI $p$

PINBIPET $\mathrm{u}$

PINBORRE $p$

PINBR

$\mathrm{u}$

PINBRAMP $\mathrm{p}^{*}$

PINCAUD $\mathrm{u}$

PINDAC $p$

PINLAT $p$

PINLATDO $p$

PINLEG $p$

PINSP $p$

PINSPB $\mathrm{p}^{*}$

PINSUB $p$

PINSUBPA $p$

PINVIR $p$

PINVIRMI $p$ 
Rhopalodia gibba (Ehr.) O. Müll. var. gibba

Stauroneis anceps Ehr. var. anceps

Stauroneis obtusa Lagerst. var. obtusa

Stauroneis pachycephala $\mathrm{Cl}$. var. pachycephala

Stauroneis palustris Hust.

Stauroneis phoenocenteron (Nitz.) Ehr. var. phoenocenteron

Stauroneis phoenocenteron f. gracilis (Ehr.) Hust.

Stauroneis smithii Grun. var. smithii

Stauroneis sp.

Stenopterobia intermedia (Lewis) V.H. var. intermedia

Stephanodiscus niagarae Ehr. var. niagarae

Stephanodiscus rotula var. minutula (Kütz.) Ross \& Sims

Surirella biseriata Bréb. var. biseriata

Surirella delicatissima Lewis

Surirella linearis $\mathrm{W}$. Sm. var. linearis

Surirella linearis var. constricta (Ehr.) Grun.

Surirella robusta Ehr. var. robusta

Surirella robusta var. splendida (Ehr.) V.H.

Surrirella sp.

Surirella tenera Greg. var. tenera

Synedra acus Kütz. var. acus

Synedra delicatissima W. Sm. var. delicatissima

Synedra delicatissima var. angustissima Grun

Synedra filiformis var. exilis $\mathrm{Cl}$.-Eul.

Synedra incisa Boyer var. incisa

Synedra miniscula Grun. var. minuscula

Synedra parasitica (W. Sm.) Hust. var. parasitica

Synedra pulchella Ralfs ex. Kütz. var. pulchella

Synedra pulchella var. lanceolata O'Meara

Synedra radians Kütz. var. radians

Synedra rumpens Kütz. var. rumpens

Synedra rumpens var. familiaris (Kütz.) Grun.

Synedra rumpens var. fragiliariodes Grun.

Synedra sp.

Synedra sp. A

Synedra ulna (Nitz.) Ehr. var. ulna

Synedra ulna var. amphirhyncus (Ehr.) Grun.

Tabellaria fenestrata (Lyngb.) Kütz. var. fenestrata

Tabellaria flocculosa (Roth) Kütz. var. flocculosa

Triceratium sp.

$\begin{array}{ll}\text { RHOPGIB } & \mathrm{p} \\ \text { STAUANC } & \mathrm{p} \\ \text { STAUOBT } & \mathrm{u} \\ \text { STAUPACH } & \mathrm{u} \\ \text { STAUPAL } & \mathrm{u}\end{array}$

STAUPH $\mathrm{p}$

STAUPHGR $\mathrm{p}$

STAUSM u

STAUSP $\mathrm{p}$

STENINT u

STEPNI u

STEPROMI e

SURBIS $\mathrm{t}-\mathrm{p}$

SURDEL $\mathrm{p}^{*}$

SURLIN $\mathrm{p}^{*}$

SURLINCO $\mathrm{p}^{*}$

SURROB u

SURROBSP $p$

SURSP u

SURTEN $u$

SYNACUS $t-p$

SYNDEL $e$

SYNDELAN e

SYNFILEX $t$ *

SYNINC u

SYNMIN u

SYNPAR p

SYNPUL $p$

SYNPULLA $p$

SYNRAD e

SYNRUM $p$

SYNRUMFA $p$

SYNRUMFR u

SYNSP u

SYNSPA u

SYNUL e

SYNULAMP e

TABFEN $p$

TABFLOC $\quad \mathrm{t}-\mathrm{p}$

TRICSP $\mathrm{p}^{*}$ 
APPENDIX 2

FORTY-SEVEN DIATOM TAXONOMIC GROUPS USED IN MUTLIVARIATE ANALYSES

Acronym for taxonomic group group composed of:

(see Appendix 1 for species acronyms)

S-ACH $\quad$ ACHBIAS + ACHEX + ACHEXCON + ACHEXHE + ACHKRY + ACHLAN + ACHLANDU + ACHLIN + ACHLINCU + ACHMIC ACHMIN + ACHPIN + ACHSP

ACTPUNC ACTPUNC

S-ANOM ANOMSE + ANOMSEAC + ANOMSEAP + ANOMSERB + ANOMVIT

S-AST ASTFOR + ASTRAL

AULAAM AULAAM

AULADIS AULADIS

S-AULAGR AULAGR + AULAGRAN

AULAISL AULAISL

AULAITAL AULAITAL

CALSPA CALSPA

COCPLACL COCPLACL

CYCMEN CYCMEN

CYCPSEUD CYCPSEUD

CYCSTEL CYCSTEL

CYCSTELO CYCSTELO

S-CYM CYMLUN + CYMMIC + CYMMIN + CYMMINSI + CYMMUEL

CYSTEPDU CTSTEPDU

S-EP $\quad$ EPARGAL + EPAD + EPSP

S-EUN $\quad$ EUNBIDT + EUNCARO + EUNCUR + EUNDIOD + EUNELEG + EUNEXIG + EUNFLEX + EUNFOR + EUNINC + EUNIND + EUNLUNA + EUNMAI + EUNMON + EUNNAE + EUNPEC + EUNPECM + EUNSP + EUNVAN + EUNVANIN

FRAGBREV FRAGBREV

S-FRAGCO FRAGCON + FRAGCONP + FRAGCONV 


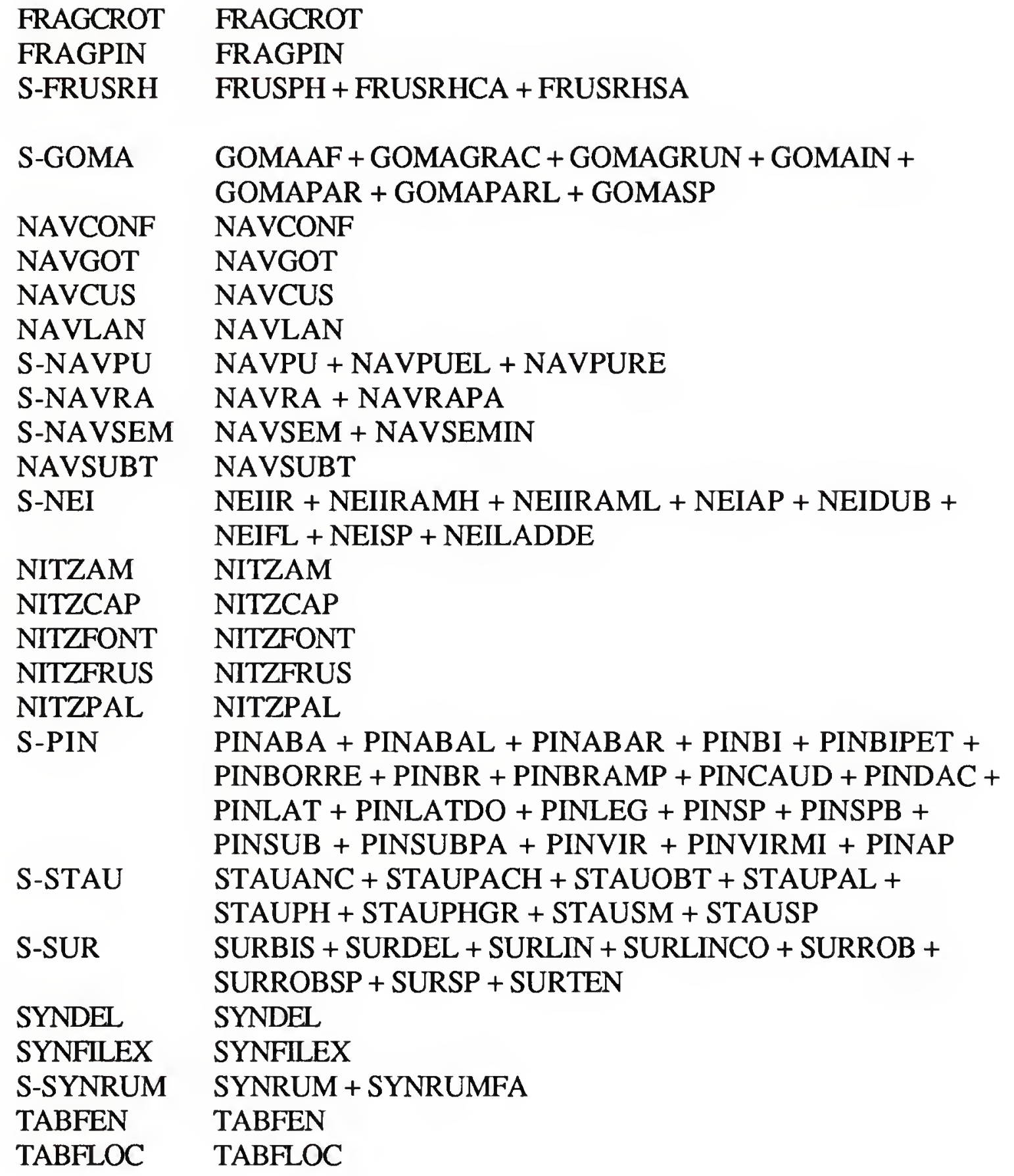




\section{APPENDIX 3}

TAXONOMIC GROUPS USED IN STEPWISE REGRESSION PROCEDURES

(Taxonomic acronyms are defined in Appendices 1 and 2.)

Key to trend in diatom representation over range of macrophyte variable

$$
\begin{aligned}
& \mathrm{i}=\text { increasing over range } \\
& \mathrm{ic}=\text { increasing in curvilinear fashion } \\
& \mathrm{d}=\text { decreasing over range } \\
& \mathrm{dc}=\text { decreasing in curvilinear fashion } \\
& \mathrm{u}=\text { uniform over range }
\end{aligned}
$$

3.1. Predicting percent-volume infestation from diatom percentage data beginning with 17 diatom taxonomic groups.

Acronym of taxonomic group

ACHEX

S-AST

S-AULAGR

AULAITAL

CYMLUN

EUNCUR

FRAGBREV

S-GOMA

S-NAVPU

NAVLAN

NAVRA

NAVSUBT

NITZAM

S-PIN

S-STAU

S-SUR

SYNDEL
Trend

d

d

d

d

i

i

d

i

i

d

d

d

d

d

i

d

d 
3.2. Predicting percent-volume infestation from diatom concentration data beginning with 17 diatom taxonomic groups.

Acronym of taxonomic group

Trend

ACHEX

$\mathrm{dc}$

ACHMIN

$\mathrm{dc}$

ANOMSERB

d

AULAAM

$\mathrm{dc}$

S-AULAGR

$\mathrm{dc}$

CALSPA

$\mathrm{dc}$

COCPLACL

d

CYCSTEL

d

CYCPSEUD

d

NAVLAN

d

$S$-NEI

$\mathrm{dc}$

NITZCAP

$\mathrm{dc}$

NITZFONT

dc

S-PIN

$\mathrm{dc}$

STAUPH

i

SYNFILEX

d

SYNRUM

dc

3.3. Predicting percent-volume infestation from log-transformed diatom accumulation rates beginning with 17 diatom taxonomic groups.

Acronym of taxonomic group

Trend

ACHEX

d

ACHMIN

d

ANOMSERB

d

AULAAM

d

S-AULAGR

d

CALSPA

d

COCPLACL

d

CYCSTEL

d

CYCPSEUD

dc 
NAVLAN

S-NEI

NITZCAP

d

NITZFONT

d

S-PIN

d

STAUPH

d

SYNFILEX

u

SYNRUM

dc

dc

3.4. Predicting percent-area coverage from diatom percentage data beginning with 11 diatom taxonomic groups.

Acronym of taxonomic group

$\log _{10}$ (ACHLIN)

S-ANOM

AULAAM

$\log _{10}$ (AULAGRAN)

CYCPSEUD

S-CYM

S-EUN

S-FRUSRH

NAVRA

STAUPH

TABFEN

\section{Trend}

i

$\mathrm{i}$

d

d

d

ic

i

i

d

i

i

3.5. Predicting percent-area coverage from diatom concentration data beginning with 8 diatom taxonomic groups.

Acronym of taxonomic group

ACHLIN

AULAAM

S-AULAGR

CYCPSEUD

CYCSTEL

EUNINC

STAUPH

SYNFILEX

\section{Trend}

ic

d

dc

d

d

ic

ic

d 
3.6. Predicting percent-area coverage from log-transformed diatom accumulation rates beginning with 11 diatom taxonomic groups.

Acronym of taxonomic group

Trend

ANOMSERB

AULAGRAN

i

CYCPSEUD

d

CYMLUN

d

CYMMIN

S-EUN

FRUSRHCA

S-GOMA

NAVPU

STAUPH

SYNFILEX

ic

i

i

i

i

d

i

d

3.7. Predicting floating-leaved biomass beginning with 9 diatom taxonomic groups identified in cluster analysis of diatom concentration data.

Acronym of taxonomic group

Trend

S-AULAGR

CYCMEN

dc

CYCPSEUD

d

CYSTELO

$\mathrm{u}$

CYSTEPDU

$\mathrm{u}$

FRAGCROT

i?

NITZFONT

i?

NITZPAL

u

S-SYNRUM

$\mathrm{u}$ ?

$\mathrm{u}$ 
3.8. Predicting floating-leaved biomass beginning with 7 diatom taxonomic groups identified from cluster analysis of diatom accumulation rates.

Acronym of taxonomic group

Trend

S-AST

$\mathrm{u}$ ?

AULAISL

d?

TABFLOC

S-NEI

d

S-NAVRA

SYNFILEX

d

TABFEN

dc

$\mathrm{dc}$

dc

3.9. Predicting floating-leaved biomass from log-transformed diatom percentage data beginning with 12 taxonomic groups.

Acronym of taxonomic group

Trend

$\log _{10}(\mathrm{ACHEX}+\mathrm{ACHLIN}+\mathrm{ACHLINCU}$ + ACHMIN)

$\log _{10}$ (S-ANOM)

d

$\log _{10}$ (AULAGR + AULAITAL +

AULAISL + AULAAM)

d

$\log _{10}$ (CYMMUEL)

$\log _{10}$ (CYSTEPDU)

$\log _{10}$ (EUNPEC)

$\log _{10}$ (S-FRUSRH)

$\log _{10}(\mathrm{NAVGOT}+\mathrm{NAVLAN}+$

S-NAVPU + S-NAVRA +

NAVSUBT)

d

$\log _{10}($ NITZAM + NITZCAP +

NITZFRUS)

d

d

i

d

d

$\log _{10}$ (SYNDEL + SYNRUM)

d

$\log _{10}$ (S-STAU)

d

$\log _{10}$ (S-SUR)

d

d 
3.10. Predicting submerged biomass from diatom percentage data beginning with 20 taxonomic groups.

Acronym of taxonomic group

Trend

$\mathrm{S}-\mathrm{ACH}$

$\mathrm{dc}$

S-ANOM

$\mathrm{d}$ ?

AULAAM

d?

S-AULAGR

(AULAISL + AULAITAL)

d

(CYCMEN + CYCPSEUD + CYCSTEL +

CYSTELO)

d

S-CYM

CYSTEPDU

d

EUNPEC

EUNVAN

d?

FRAGCROT

d

d

S-FRUSRH

d?

S-NAVRA

dc

NAVSUBT

d

S-NEI

d

S-NITZ

d

S-PIN

d

S-STAU

d

S-SUR

d

(SYNDEL + S-SYNRUM)

d

d

3.11. Predicting floating + submerged biomass from diatom percentage data beginning with 16 taxonomic groups.

Acronym of taxonomic group

Submerged

$$
\text { Trend }
$$

Floating

S-ACH

S-ANOM

(AULAISL + AULAITAL)

S-CYM

CYSTEPDU d

d

d

dc

d? d

d

d

$\mathrm{dc}$

i? 


\begin{tabular}{lll} 
EUNPEC & $\mathrm{d}$ & $\mathrm{d}$ \\
S-FRUSRH & $\mathrm{dc}$ & $\mathrm{dc}$ \\
\multicolumn{2}{c}{ (NAVGOT + NAVLAN + S-NAVPU } & \\
+ S-NAVRA + NAVSUBT) & $\mathrm{d}$ & $\mathrm{d}$ \\
S-NITZ & $\mathrm{u}$ & $\mathrm{d}$ \\
S-STAU & $\mathrm{d}$ & $\mathrm{d}$ \\
S-SUR & $\mathrm{d}$ & $\mathrm{d}$ \\
(SYNDEL + SYNRUM) & $\mathrm{d}$ & $\mathrm{d}$ \\
FRAGCROT & $\mathrm{d} ?$ & $\mathrm{i} ?$ \\
EUNVAN & $\mathrm{d}$ & $\mathrm{d}$ \\
S-AULAGR & $\mathrm{u}$ & $\mathrm{d}$ \\
AULAAM & $\mathrm{d}$ & $\mathrm{d}$
\end{tabular}

3.12. Predicting emergent biomass from diatom percentage data beginning with17 taxonomic groups.

Acronym of taxonomic group

Trend

$($ ACHEX + ACHLIN + ACHLINCU

$\begin{array}{ll}\begin{array}{l}+ \text { ACHMIN) } \\ \text { (AULAM + AULAGR + AULAITAL) }\end{array} & \mathrm{d} \\ \text { CYCMEN } & \mathrm{d} \\ \text { CYCPSEUD } & \mathrm{d} \\ \text { CYCSTEL } & \mathrm{d} \\ \text { S-CYM } & \mathrm{d} \\ \text { EUNPEC } & \mathrm{d} \\ \text { FRAGCONV } & \mathrm{d} \\ \text { S-FRUSRH } & \mathrm{d} \\ \text { FRAGPIN } & \mathrm{d} \text { ? } \\ \text { S-NAVRA } & \mathrm{d} \\ \text { NAVSUBT } & \mathrm{d} \\ \text { S-NITZ } & \mathrm{d} \text { ? } \\ \text { S-PIN } & \mathrm{d} \\ \text { S-SUR } & \mathrm{d} \\ \text { TABFEN } & \mathrm{d} \\ \text { S-SYNRUM } & \mathrm{d}\end{array}$




\section{APPENDIX 4}

CHL $A$, TOTAL N, AND SECCHI DEPTH VALUES USED TO CALCULATE TSI(AVG)

$\begin{array}{lllc}\text { Lake } & \begin{array}{l}\text { Chl } a \\ \left(\mu \mathrm{g} \mathrm{l}^{-1}\right)\end{array} & \begin{array}{l}\text { Total N } \\ \left(\mathrm{mg} \mathrm{l}^{-1}\right)\end{array} & \begin{array}{c}\text { Sechi depth } \\ (\mathrm{m})\end{array}\end{array}$

$\begin{array}{lrrr}\text { Alligator } & 25.4 & 2.37 & 0.46 \\ \text { Apopka } & 59.3 & 4.03 & 0.20 \\ \text { Bonny } & 36.5 & 1.86 & 0.58 \\ \text { Carr } & 7.0 & 0.87 & 1.81 \\ \text { Catherine } & 1.5 & 0.30 & 3.20 \\ \text { Clay } & 2.1 & 0.36 & 4.00 \\ \text { Crooked } & 1.8 & 0.33 & 3.13 \\ \text { Deep } & 0.9 & 0.16 & \\ \text { Fairview } & 2.4 & 0.50 & 4.80 \\ \text { Harris } & 37.2 & 1.55 & 0.60 \\ \text { Hartridge } & 3.7 & 0.48 & 2.32 \\ \text { Keys Pond } & 1.0 & 0.17 & 5.25 \\ \text { Lindsey } & 5.2 & 0.65 & 1.95 \\ \text { Live Oak } & 5.3 & 0.35 & 2.55 \\ \text { Lochloosa } & 26.5 & 1.05 & 0.97 \\ \text { Loften Ponds } & 1.2 & 0.39 & 2.48 \\ \text { Moore } & 3.5 & 0.35 & 5.28 \\ \text { Mystic } & 3.6 & 0.52 & 7.00 \\ \text { Ocean Pond } & 3.9 & 0.42 & 1.10 \\ \text { Okahumpka } & 5.1 & 0.95 & 1.20 \\ \text { Orange } & 16.8 & 1.11 & 0.80 \\ \text { Patrick } & 4.0 & 1.47 & 2.00 \\ \text { Rowell } & 37.8 & 0.81 & 0.65\end{array}$


Stella

Tomohawk

Townsend

Watertown

Wauberg

Wildcat
2.0

1.2

5.1

15.9

114.7

1.2
0.43

0.21

0.58

1.05

1.57

0.19
4.10

4.00

3.80

1.90

0.57

3.61 


\section{APPENDIX 5}

\section{SUBJECTIVE TROPHIC STATE CLASSIFICATION OF LAKES IN SURVEY}

Key to Trophic Classification categories:

$$
\begin{aligned}
& U=\text { ultraoligotrophic } \\
& O=\text { oligotrophic } \\
& M=\text { mesotrophic } \\
& E=\text { eutrophic } \\
& H=\text { hypereutrophic }
\end{aligned}
$$

\begin{tabular}{llll}
\hline \hline & \multicolumn{3}{c}{ Classification based on: } \\
\cline { 2 - 4 } & $\begin{array}{c}\text { Lake } \\
\text { water-column } \\
\text { nutrients }\end{array}$ & $\begin{array}{c}\text { macrophyte } \\
\text { presence }\end{array}$ & overall \\
\hline & & & \\
Alligator & $\mathrm{H}$ & $\mathrm{O}$ & $\mathrm{H}$ \\
Apopka & $\mathrm{H}$ & $\mathrm{O}$ & $\mathrm{H}$ \\
Bonny & $\mathrm{E}$ & $\mathrm{O}$ & $\mathrm{H}$ \\
Carr & $\mathrm{M}$ & $\mathrm{H}$ & $\mathrm{H}$ \\
Catherine & $\mathrm{U}$ & $\mathrm{M}$ & $\mathrm{M}$ \\
Clay & $\mathrm{U}$ & $\mathrm{H}$ & $\mathrm{H}$ \\
Crooked & $\mathrm{O}-\mathrm{M}$ & $\mathrm{O}-\mathrm{M}$ & $\mathrm{O}-\mathrm{M}$ \\
Deep & $\mathrm{U}$ & $\mathrm{E}$ & $\mathrm{E}$ \\
Fairview & $\mathrm{M}$ & $\mathrm{M}$ & $\mathrm{M}$ \\
Harris & $\mathrm{M}$ & $\mathrm{O}-\mathrm{M}$ & $\mathrm{M}$ \\
Hartridge & $\mathrm{O}$ & $\mathrm{M}$ & $\mathrm{M}$ \\
Keys Pond & $\mathrm{U}$ & $\mathrm{M}$ & $\mathrm{M}$ \\
Lindsey & $\mathrm{M}$ & $\mathrm{H}$ & $\mathrm{H}$ \\
Live Oak & $\mathrm{M}$ & $\mathrm{H}$ & $\mathrm{H}$ \\
Lochloosa & $\mathrm{E}$ & $\mathrm{E}$ & $\mathrm{E}$ \\
Loften Ponds & $\mathrm{U}$ & $\mathrm{M}-\mathrm{E}$ & $\mathrm{M}-\mathrm{E}$ \\
Moore & $\mathrm{O}$ & $\mathrm{M}$ & $\mathrm{M}$ \\
& & &
\end{tabular}




$\begin{array}{llll}\text { Mystic } & \text { M } & \text { H } & \text { H } \\ \text { Ocean Pond } & \text { E } & \text { U } & \text { E } \\ \text { Okahumpka } & \text { M } & \text { H } & \text { H } \\ \text { Orange } & \text { E } & \text { H } & \text { H } \\ \text { Patrick } & \text { M } & \text { H } & \text { H } \\ \text { Rowell } & \text { E } & \text { M } & \text { E } \\ \text { Stella } & \text { M } & \text { E } & \text { E } \\ \text { Tomohawk } & \text { U } & \text { M } & \text { M } \\ \text { Townsend } & \text { O } & \text { H } & \text { H } \\ \text { Watertown } & \text { E } & \text { O } & \text { E } \\ \text { Wauberg } & \text { H } & \text { U } & \text { O } \\ \text { Wildcat } & \text { O } & \text { U } & \text { O }\end{array}$




\section{APPENDIX 6}

PROPORTIONS, SEDIMENTARY CONCENTRATIONS, AND ANNUAL ACCUMULATION RATES OF PERIPHYTIC AND PLANKTONIC DIATOMS 


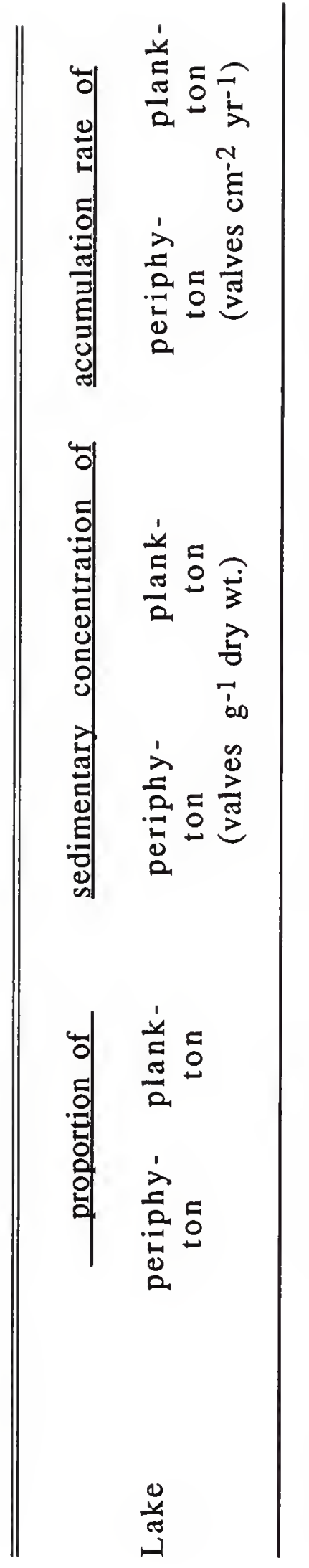

n-

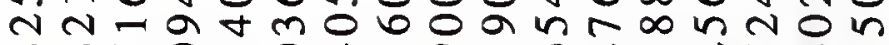
$\infty \infty$ in $000+\pi 0=1 \pi N$

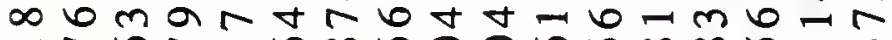

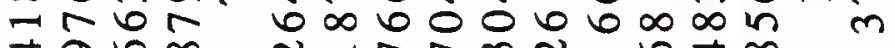

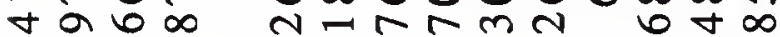
$\infty \pi$ I

$0 \pi N O N+0,0$ N $\infty$ nn a $00 \infty \pi-n$ n $\infty$ b $0 \pi=\infty$

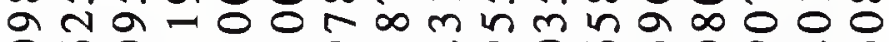

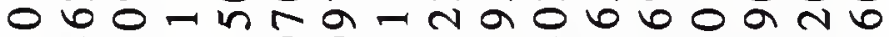
- ta a $000-1 n n+m b=\infty$

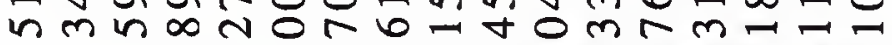

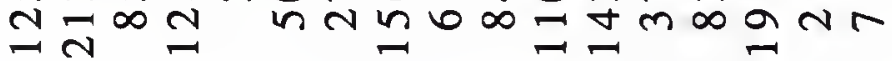

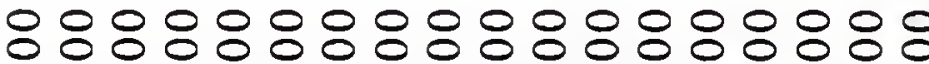
0
0

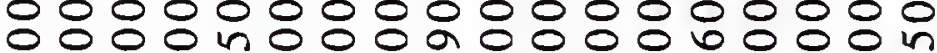

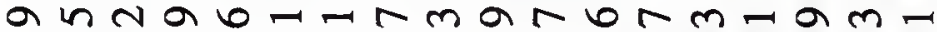

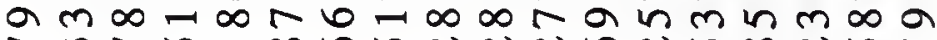

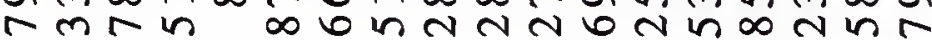

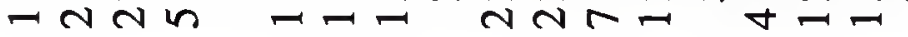

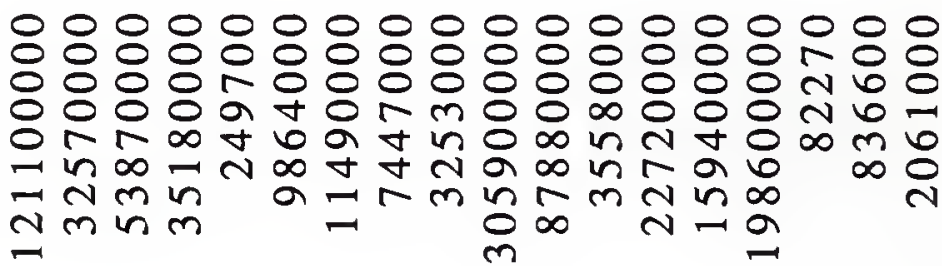
b- 0 m

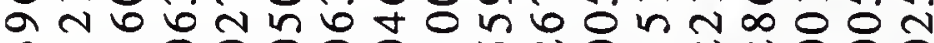

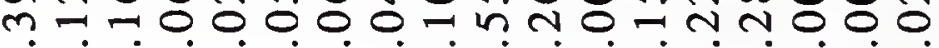
$\dot{0} \dot{0} \dot{0} \dot{0} \dot{0} \dot{0} \dot{0} \dot{0} \dot{0} \dot{0} \dot{0} \dot{0} \dot{0} \dot{0} \dot{0}$

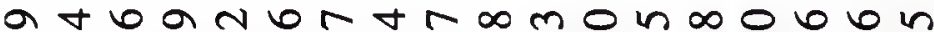
$\infty 6 \mathrm{~N}$ ( n $\infty \infty$ a a a a a $\infty$ t 6 a $\infty \mathrm{r}$ a a a

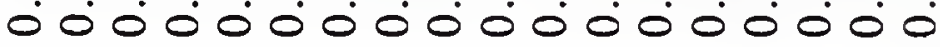

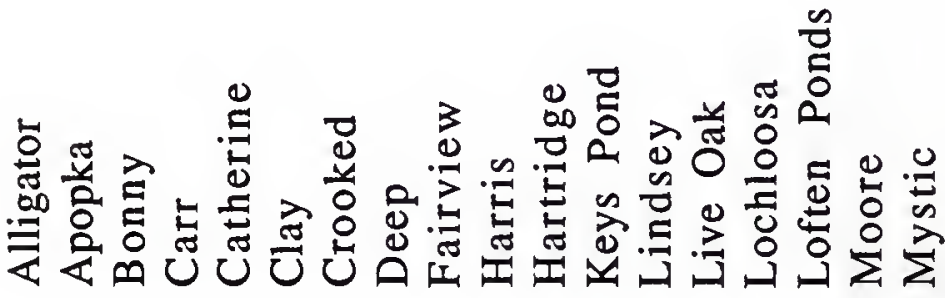




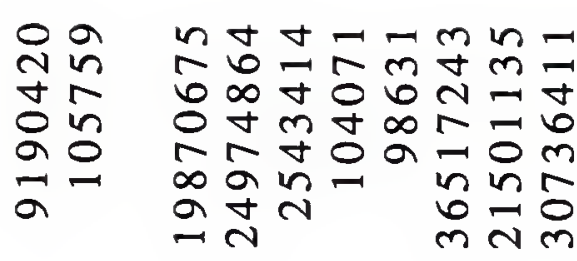

n 6 オ

an $n+4 a 0+\infty$ a $m \quad m$ a n न $010 \pi N \times \infty$ -n NO nNmb-1 0 मी $0 \mathrm{~N}$ in $\infty$ $\infty$ 대
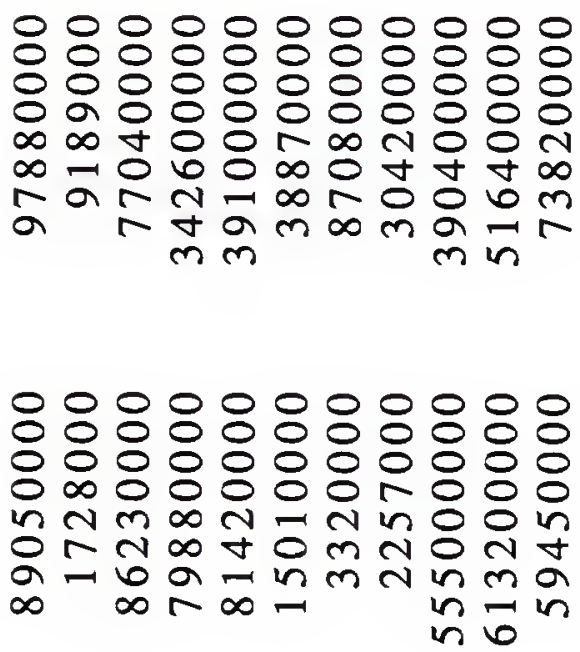

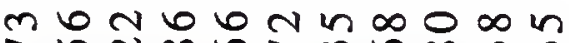

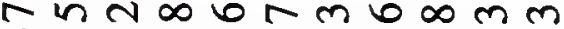
$\forall-n-\pi 00$ n $\dot{0} \dot{0} \dot{0} \dot{0} \dot{0} \dot{0} \dot{0} \dot{0}$

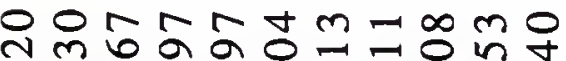

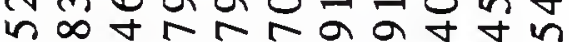
$\dot{0} \dot{0} \dot{0} \dot{0} \dot{0} \dot{0} \dot{0} \dot{0} \dot{0}$

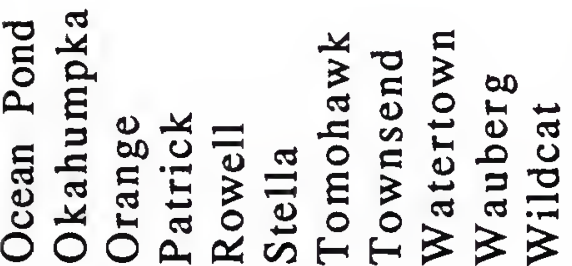




\section{BIBLIOGRAPHY}

Agbeti, M. and M. Dickman. 1987. Use of lake fossil diatom assemblages to determine historical changes in trophic status. Can. J. Fish. Aquat. Sci., 46: 1013-1021.

Allen, H.L. and B.T. Ocevski. 1981. Comparative primary productivity of algal epiphytes on 3 species of macrophyte in the littoral zone of Lake Ohrid, Yugoslavia. Holarct. Ecol., 4(3): $155-160$.

Anderson, N.J. 1990a. Variability of diatom concentrations and accumultion rates in sediments of a small lake basin. Limnol. Oceanogr., 35(2): 497-508.

1990b. Spatial pattern of recent sediment and diatom accumulation in a small, monomictic, eutrophic lake. Journal of Paleolimnology, 3: 143-160.

1990c. Diatom paleoproductivity versus diatom inferred whole-lake paleoproductivity. 11th International Symposium on Living and Fossil Diatoms, San Francisco, 13-17 August, 1990. Abstract.

Bailey, J.H. and R.B. Davis. 1978. Quantitative comparison of lake water quality and surface sediment diatom assemblages in Maine, U.S.A. lakes. Verh. Internat. Verein. Limnol., 20: 531.

Baker, L.A., P.L. Brezonik and C.R. Kratzer. 1981. Nutrient loadingtrophic state relationships in Florida lakes. Florida Water Resources Research Center, Pub. no. 56. 126 p.

Battarbee, R.W. 1973. A new method for the estimation of absolute microfossil numbers, with reference especially to diatoms. Limnol. Oceanogr., 18(4): 647-653. 
1978. Observations on the recent history of Lough Neagh and its drainage basin. Phil. Trans. R. Soc. Lond. Ser. B, 281: 303-344.

1979. Diatoms in lake sediments, p. 177-225. In B.E. Berglund (ed.), Paleohydrological Changes in the Temperate Zone in the Last 15000 Years, Subproject B. Lake and Mire Environments, V. II. Specific methods. International Geological Correlation Programme. Lund, Sweden.

R.J. Flower, A.C. Stevenson, V.J. Jones, R. Harriman and P.G. Appleby. 1988. Diatom and chemical evidence for reversibility of acidification of Scottish lochs. Nature 332(6164): 530-532.

Binford, M.W. and M. Brenner. 1986. Dilution of $210 \mathrm{~Pb}$ by organic sedimentation in lakes of different trophic states, and application to studies of sediment-water interactions. Limnol. Oceanogr. 31: 584-595.

Birks, H.H. 1973. Modern macrofossil assemblages in lake sediments in Minnesota. Pages 173-188. In H.J.B. Birks and R.G. West (eds.). Quaternary Plant Ecology. John Wiley and Sons, NY, New York, U.S.A. 326 p.

1980. Plant macrofossils in Quaternary lake sediments. In H.J. Elster and W. Ohle (eds.). Ergebnisse der Limnologie. Heft 15. E. Schweizerbart'sche Verlagsbuchhandlung (Nägele u. Obermiller), Stuttgart. 60 p.

Blindow, I. 1987. The composition and density of epiphyton on several species of submerged macrophytes- the neutral substrate hypothesis tested. Aquat. Bot., 29: 157-168.

Bradbury, J.P. 1975. Diatom stratigraphy and human settlement in Minnesota. Geol. Soc. Am. Spec. Pap. 171. Boulder, Colorado. 74 p.

Brenner, M. , M.W. Binford and E.S. Deevey. 1990. Lakes, p. 364 391. In R.L. Myers and J.J. Ewel (eds.), Ecosystems of Florida. University of Central Florida Press, Orlando, FL. 
Brugam, R.B. 1978. Human disturbance and the historical development of Linsley Pond. Ecology, 59(1): 19-36.

1979. A re-evalution of the Araphidineae/Centrales index as an indicator of lake trophic status. Freshwater Biol., 9: $451-460$.

Burkholder, J.M. and R.G. Wetzel. 1990. Epiphytic alkaline phosphatase on natural and artificial plants in an oligotrophic lake: Re-evaluation or the role of macrophytes as a phosphorus source for epiphytes. Limnol. Oceanogr., 35(3): 736-747.

Canfield, D.E., Jr. 1981. Final report: Chemical and trophic state characteristics of Florida lakes in relation to regional geology. Institute of Food and Agricultural Studies, Univ. Florida, Gainesville, 434 p.

and C.M. Duarte. 1988. Patterns in biomass and cover of aquatic macrophytes in lakes: a test with Florida lakes. Can. J. Fish. Aquat. Sci., 45:1976-1982.

and M.V. Hoyer. 1988. Influence of nutrient enrichment and light availability on the abundance of aquatic macrophytes in Florida streams. Can. J. Fish. Aquat. Sci., 45: 1467-1472.

K.A. Langeland, M.J. Maceina, W.T. Haller and J.V. Shireman. 1983a. Trophic state classification of lakes with aquatic macrophytes. Can. J. Fish. Aquat. Sci., 40: 1713-1718.

M.J. Maceina and J.V. Shireman. 1983b. Effects of Hydrilla and grass carp on water quality in a Florida lake. Water Resources Bulletin 19(5): 773-778.

J.V. Shireman, D.E. Colle, W.T. Haller, C.E. Watkins, II, and M.J. Maceina. 1984. Prediction of Chlorophyll $a$ concentrations in Florida lakes: importance of aquatic macrophytes. Can. J. Fish. Aquat. Sci., 41: 497-501.

Carignan, R. and J. Kalff. 1980. Phosphorus sources for aquatic weeds: water or sediments? Science, 207: 987-989. 
and

1982. Phosphorus release by

submerged macrophytes: significance to epiphyton and phytoplankton. Limnol. Oceanogr., 27(3): 419-427.

Carlson, R.E. 1977. A trophic state index for lakes. Limnol. Oceanogr., 22(2): 361-369.

Carney, H.J. 1982. Algal dynamics and trophic interactions in the recent history of Frains Lake, Michigan. Ecology, 63(6): 18141826.

Carpenter, S.R. 1981. Submersed vegetation: an internal factor in lake ecosystem succession. Am. Nat., 118(3): 372-383.

and D.M. Lodge. 1986. Effects of submersed macrophytes on ecosystem processes. Aquat. Bot., 26: 341-370.

Cattaneo, A. 1987. Periphyton in lakes of different trophy. Can. J. Fish. Aquat. Sci., 44: 296-303.

and J. Kalff. 1979. Primary production of algae growing on natural and artificial aquatic plants: A study of interactions between epiphytes and their substrate. Limnol. Oceanogr., 24: 1031-1037.

and

1980. The relative contribution of aquatic macrophytes and their epiphytes to the production of macrophyte beds. Limnol. Oceanogr., 25: 280-289.

and 1981. Reply to comment by Gough and Gough. Limnol. Oceanogr., 26(5): 988-989

Charles, D. 1984. Recent pH history of Big Moose Lake (Adirondack Mountains, New York, U.S.A.) inferred from sediment diatom assemblages. Verh. Internat. Verein. Limnol., 22: 1-7.

1985. Relationships between surface sediment diatom assemblages and lakewater characteristics in Adirondack lakes. Ecol., 66(3): 994-1011. 
Christie, C.E. and J.P. Smol. 1990. Paleolimnological reconstructions of nutrient concentrations using diatom assemblages and weighted averageing techniques. 11 th International Symposium on Living and Fossil Diatoms, San Francisco, 13-17August, 1990. Abstract.

Collins, C.D., Sheldon, R.B. and C.W. Boylen. 1987. Littoral zone macrophyte community structure: distribution and association ofspecies along physical gradients in Lake George, New York, U.S.A. Aquat. Bot., 29: 177-194.

Crowder, A.A. , J.M. Bristow, M.R. King and S. Vanderkloet. 1977. The aquatic macrophytes of some lakes in southeastern Ontario. Nat. Can. (Que.), 104: 457-464.

Daniel, C. and F.S. Wood. 1971. Fitting equations to data. WileyInterscience, N.Y. 342 p.

Davis, F.W. 1985. Historical changes in submerged macrophyte communities of upper Chesapeake Bay. Ecol., 66(3): 981-993.

Davis, R.B. 1987. Paleolimnological diatom studies of acidification of lakes by acid rain: an application of Quaternary Science. Quat. Sci. Rev., 6: 147-163.

and D.S. Anderson. 1985. Methods of $\mathrm{pH}$ calibration of sedimentary diatom remains for reconstructing history of $\mathrm{pH}$ in lakes. Hydrobiologia, 120: 69-87.

and F. Berge. 1980. Atmospheric deposition in Norway during the last 300 years as recorded in SNSF lake sediments II. Diatom stratigraphy and inferred $\mathrm{pH}$. Proc. Int. Ecol. Impact. Precip., Norway 1980, SNSF project.

Deevey, E.S., Jr. 1988. Estimation of downward leakage from Florida lakes. Limnol. Oceanogr., 33: 1308-1320.

Dixit, S.S. and R.D. Evans. 1986. Spatial variability in algal microfossils and its bearing on diatom-inferred $\mathrm{pH}$ reconstructions. Can. J. Fish. Aquat. Sci., 43: 1836-1845. 
Duarte, C.M. and J. Kalff. 1990. Patterns in the submerged macrophyte biomass of lakes and the importance of the scale of analysis in the interpretation. Can. J. Fish. Aquat. Sci., 47: 357363.

Eakins, J.D. and R.T. Morrison. 1978. A new procedure for the determination of lead-210 in lake and marine sediments. Int. J. Appl. Radiat. Isotopes, 29: 531-536.

Earle, J.C., H.C. Duthie, W.A. Glooschenko and P.B. Hamilton. 1988. Factors affecting the spatial distribution of diatoms on the surface sediments of three Precambrian shield lakes. Can. J. Fish. Aquat. Sci., 45: 469-478.

Eminson, D. and B. Moss. 1980. The composition and ecology of periphyton communities in freshwaters. 1. The Influence of host type and external environment on community composition. Br. phycol. J., 15: 429-446.

Ennis, G.L. 1975. Distribution and abundance of benthic algae along phosphate gradients in Kootenay Lake, British Columbia. Verh. Internat. Ver. Limnol., 19: 562-570.

Filbo, G.J. and J.W. Barko. 1985. Growth and nutrition of submersed macrophytes in a eutrophic Wisconsin (U.S.A.) impoundment. Freshwater Ecol., 3(2): 275-285.

Fontaine, T.D., III and K. C. Ewel. 1981. Metabolism of a Florida lake ecosystem. Limnol. Oceanogr., 26(4): 754-763.

Fritz, S.C. 1990. Twntieth-century salinity and water-level fluctuations in Devils Lake, North Dakota: Test of a diatombased transfer function. Limnol. Oceanogr., 35: 1771-1781.

Gough, S.B. and L.P. Gough. 1981. Comment on "Primary production of algae growing on natural and artificial aquatic plants: A study of interactions between epiphytes and their substrate" (Cattaneo and Kalff). Limnol. Oceanogr., 26(5): 987-988.

Håkansson, H. 1982. The recent diatom succession of Lake Håvgardssjön, south Sweden. In D.G. Mann (ed.). Proceedings of the Seventh International Diatom Symposium, Philadelphia, 2227 August,1982. p. 411-429. 
Hall, R.I. and J.P. Smol. 1990. A calibration of surficial sediment diatom assemblages from British Columbia lakes along a trophic gradient. 11th International Symposium on Living and Fossil Diatoms, San Francisco, 13-17 August, 1990. Abstract.

Hansson, L.A. 1988. Effects of competitive interactions on the biomass development of planktonic and periphytic algae in lakes. Limnol. Oceanogr., 33(1): 121-128.

Hill, M.O. and H.G. Gaugh, Jr. 1980. Detrended correspondence analysis: an improved ordination technique. Vegetatio, 42: 4758 .

Hodgson, L.M., S.B. Linda and D.E. Canfield, Jr. 1986. Periphytic algal growth in a hypereutrophic Florida lake following a winter decline in phytoplankton. Florida Scientist, 49: 234-241.

Hoyer, M.V. and D.E. Canfield, Jr. 1986. Surface area of aquatic macrophytes. Aquatics. 8(2): 26-27.

Huber, W.C., P.L. Brezonik, J.P. Heany, R.E. Dickinson, S.D. Preston, D.S. Dwornik and M.A. DeMaio. 1982. A classification of Florida lakes. Final report to the Florida Department of Environmental Regulation, Report ENV-05-82-1, Tallahassee, Florida. v. 1-2. 547 p.

Hudson, C. and P. Legendre. 1987. The ecological implications of growth forms in Epibenthic diatoms. J. Phycol., 23:434-441.

Hustedt, F. 1930. Die süsswasser flora Mitteleuropas. Heft 10. Bacillariophyta (Diatomeae). Jena. Gustav Fischer. 466 p.

Österreichs und der Schweiz. In Dr. L. Rabenhorst's

Kryptogamen Flora von Deutschlands, Österreichs und der Schweiz. Band 7. Teil 1-3.

1937-1938. Systematische und ökologische Untersuchungen über die diatomeen Flora von Java, Bali and Sumatra. Arch. f. Hydrobiol., Supplement-Band, 15: 131-177, 16: 187-295, 16: 393-506. 
Hutchinson, G.E. 1975. A treatise on limnology, v. 3. Wiley \& Sons, Inc. New York. $660 \mathrm{p}$.

Huttunen, P. and J. Meriläinen. 1986. Applications of multivariate techniques to infer limnological conditions from diatom assemblages. In J.P. Smol, R.W. Battarbee, R.B. Davis and J. Meriläinen (eds.). Diatoms and Lake Acidity. Dr. W. Junk Publishers, Dordrecht. 307 p.

Jackson, S.T. and D.F. Charles. 1988. Aquatic macrophytes in Adirondack (New York) lakes: patterns of species composition in relation to environment. Can. J. Bot., 66: 1449-1460.

Kilham, P. 1971. A hypothesis concerning silica and the freshwater planktonic diatoms. Limnol. Oceanogr., 16(1): 10-18.

Kratzer, C.R. and P.L. Brezonik. 1981. a Carlson-type trophic state index for nitrogen in Florida lakes. Water Resour. Bull., 17: 713715 .

Landers, D.H. 1982. Effects of naturally senescing aquatic macrophytes on nutrient chemistry and chlorophyll $a$ of surrounding waters. Limnol. Oceanogr., 27(3) 428-439.

Line, J.M. and H.J.B. Birks. 1990. WACALIB version 2.1- a computer program to reconstruct environmental variables from fossil diatom assemblages by weighted averaging. Journal of Paleolimnology, 3(2): 170-173.

Lowe, R.L. 1974. Environmental requirements and pollution tolerance of freshwater diatoms. U.S. Environmental Protection Agency Report EPA-670/4-74-005, National Environmental Research Center, Cincinnati, Ohio. 334 p.

Maceina, M.J. and J.V. Shireman. 1980. The use of a recording fathometer for determination of distribution and biomass of Hydrilla. J. Aquat. Plant Manage., 18: 34-39.

Menzel, D.W. and N. Corwin. 1965. The measurement of total phosphorus in seawater based on the liberation of organically bound fractions by persulfate oxidation. Limnol. Oceanogr., 10: 280-282. 
Murphy, J. and J.P. Riley. 1962. A modified single solution method for the determination of phosphate in natural waters. Anal. Chim. Acta, 27: 31-36.

Nelson, D.W. and L.E. Sommers. 1975. Determination of total nitrogen in natural waters. J. Environ. Qual., 4: 465-468.

Nygaard, G. 1949. Hydrobiological studies on some Danish ponds and lakes, II. The quotient hypothesis and some new or little known phytoplankton organisms. Det. Kingel. Dansk. Vid. Selsk. Biol. Skr., 7: 1-293.

1956. Ancient and recent flora of diatoms and chrysophyceae in Lake Gribsø, p. 32-94. In K. Berg and I.B.C. Peterson. Studies on the Humic, Acid Lake Gribsø. Fol. Limnol. Scand., 8.

Ott, L. 1977. An introduction to statistical methods and data analysis. Duxbury Press. North Scituate, Mass., 730 p.

Parsons, T.R. and J.D. Strickland. 1963. Discussion of spectrophotometric determination of marine-plant pigments, with revised equations for ascertaining chlorophylls and carotenoids. J. Mar. Res., 21: 155-163.

Patrick, R. 1973. Use of algae, especially diatoms, in the assessment of water quality. Biological methods for the assessment of water quality, ASTM STP 528, American Society for Testing and Materials, 1973, p. 76-95.

and C.W. Reimer. 1966-1975. The Diatoms of the United States. Monogr. Acad. Sci. Phila., No. 13, Part 1, v. 1-2.

Porcella, D.B., S.A. Peterson and D.P. Larsen. 1980. An index to evaluate lake restoration. U.S.G.S., Water Supply Paper 1454, U.S. Government Printing Office, Washington, D.C.

Purohit, R. and S.P. Singh. 1985. Submerged macrophytic vegetation in relation to eutrophication level in Kumaun Himalaya (India). Environ. Pollut. Ser. A Ecol. Biol., 39(2): 161-174. 
Renberg, I. and T. Hellberg. 1982. The pH history of lakes in southwestern Sweden, as calculated from the subfossil diatom flora of the sediments. Ambio, 11(1): 30-33.

Richard, D.I., J.W. Small, Jr. and J.A. Osborne. 1984. Phytoplankton responses to reduction and elimination of submerged vegetation by herbicides and grass carp in four Florida lakes. Aquat. Bot., 20: $307-319$.

Robinson, C.T. and S.R. Rushforth. 1987. Effects of physical disturbance and canopy cover on attached diatom community structure in an Idaho stream. Hydrobiologia, 154: 49-59.

Roemer, S.C., K.D. Hoagland and J.R. Roscowski. 1984. Development of a freshwater periphyton community as influenced by diatom mucilages. Can. J. Bot., 62: 1799-1813.

Round, F.E. 1956. A note on some communities of the littoral zone of lakes. Arch. f. Hydrobiol., 52(3): 398-405.

Sand-Jensen, K. and M. Sondergaard. 1981. Phytoplankton and epiphyte development and their shading effect on submerged macrophytes in lakes of different nutrient status. Int. Rev. Gesamten Hydrobiol., 66(4): 529-552.

SAS Institute, Inc. 1985. SAS User's Guide: Statistics. SAS Institute, Inc., Cary, North Carolina. 956 p.

Schardt, J.D. 1983. 1983 Aquatic Flora of Florida Survey Report. Bur. Aquat. Plant Res. Control, Florida Dep. Nat. Resour., Tallahassee. $116 \mathrm{p}$.

Schelske, C.L. 1988. Historic trends in Lake Michigan silica concentrations. Int. Revue ges. Hydrobiol. 73(5): 559-591.

E.F. Stoermer, D.J. Conley, J.A. Robbins and R.M. Glover. 1983. Early eutrophication in the lower Great Lakes: New evidence from biogenic silica in sediments. Science 222: 320322 .

Servant-Vildary, S. and M. Roux. 1990. Multivariate analysis of diatoms and water chemistry in Bolivian saline lakes. Hydrobiologia, 197: 267-290. 
Shannon, E.E. and P.L. Brezonik. 1972. Relationships between lake trophic state and nitrogen and phosphorus loading rates. Envir. Sci. Tech., 6(8): 719-725.

Shireman, J.V. and M.J. Maceina. 1981. The utilization of grass carp, Ctenopharyngodon idella Val., for hydrilla control in Lake Baldwin, Florida. J. Fish. Biol. 19: 629-636.

Shortreed, K.S., A.C. Costella and J.G. Stockner. 1984. Periphyton biomass and species composition in 21 British Columbia lakes: seasonal abundance and response to whole-lake nutrient additions. Can. J. Bot., 62: 1022-1031.

Siver, P.A. 1978. Development of diatom communities on Potamogeton robbinsii Oakes. Rhodora, 80: 417-431.

Stockner, J.G. 1971. Paleolimnology as a means of assessing eutrophication. Verh. Internat. Verein. Limnol., 18:1018-1030. and F.A. Armstrong. 1971. Periphyton of the Experimental Lakes Area (ELA), northwestern Ontario. J. Fish. Res. Board Can., 28: 215-229.

and W.W. Benson. 1967. The succession of diatom assemblages in the recent sediments of Lake Washington. Limnol. Oceanogr., 12: 513-532.

Stoermer, E.F., J.A. Wolin, C.L. Schelske and D.J. Conley. 1990. Siliceous microfossil succession in Lake Michigan. Limnol. Oceanogr., 35(4): 959-967.

Tarver, D.P., J.A. Rodgers, M.J. Mahler, R.L. Lazor. 1979. Aquatic and wetland plants of Florida. Bureau of Aquatic Plant Research and Control, Flor. Dept. of Nat. Res., Tallahassee. 127 p.

ter Braak, C.J.F. 1987. CANOCO - a FORTRAN program for canonical community ordination. TNO Institute of Applied Computer Science, Wageningen, Netherlands. 
Van Dam, H., G. Suurmond and C. ter Braak. 1980. Impact of acid precipitation on diatoms and chemistry of Dutch moorland pools. Proc. Int. Conf. Ecol. Impact Acid Precip., Norway 1980, SNSF project.

Van der Werff, A. 1955. A new method of concentrating and cleaning diatoms and other organisms. Verh. Internat. Verein. Limnol., 12: 276-277.

Watts, W.A. 1978. Plant macrofossils and Quaternary paleoecology. p. 89-99. In E.J. Cushing and H.E. Wright (eds.). Quaternary Paleoecology. Yale University Press, New Haven.

Whitmore, T.J. 1985. Diatom transfer functions for assessing the cultural eutrophication of Florida lakes. Master's Thesis, Univ. of Florida, Gainesville. 143 p.

1989. Florida diatom assemblages as indicators of trophic state and pH. Limnol. Oceanogr. 34(5): 882-895.

in press. Sedimentary diatom concentrations and accumulation rates as predictors of lake trophic state. Hydrobiologia.

Yentsch, C.S. and D.W. Menzel. 1963. A method for the determination of phytoplankton chlorophyll and phaeophytin by flourescence. Deep Sea Res., 10: 221-231.

Yeo, R.R. 1966. Yields of propagules of certain aquatic plants. Weeds, 14: 110-113. 


\section{BIOGRAPHICAL SKETCH}

Thomas J. Whitmore was born in Bridgeport, Connecticut on July 27, 1955. Tom graduated from the University of Connecticut in 1977 with a Bachelor of Science degree from the Biology Department. His studies emphasized geology and paleontology, and included a 12credit independent study on the paleoecology of the Miocene and Pliocene sediments of the South Carolina coastal plain. Tom completed a graduate course in micropaleontology at Western Connecticut State College and entered the University of Florida for graduate work in 1979.

Though intending research in invertebrate paleontology, Tom met Edward S. Deevey, Jr. and began studies with Ed on the paleolimnology of Florida lakes. Tom studied the "Ecology and Systematics of Diatoms" with Charles Reimer at Iowa Lakeside Laboratory in the summer of 1981, and submitted his master's thesis entitled "Diatom Transfer Functions for Assessing the Cultural Eutrophication of Florida Lakes" in 1985.

Tom continued graduate work in Ed Deevey's laboratory at the Florida Museum of Natural History until Ed's death in 1988. In 1990, Ed's lab relocated to join Claire Schelske in the Department of Fisheries and Aquaculture at the University of Florida. Tom continued graduate studies under the guidance of Frank Nordlie, Chairman of the Department of Zoology. He also participated in field 
work and research in 1989-90 on the paleolimnology of the Yunnan Plateau of China under the direction of Mark Brenner, his long-time friend and colleague.

Tom's professional interests include further research on assessing the trophic trajectories of lakes, reconstructing climatic and anthropogenic influences on lakes in southern China, and interpreting long-term climatic patterns in Florida from lake sedimentary indicators. 
I certify that I have read this study and that in my opinion it conforms to acceptable standards of scholarly presentation and is fully adequate, in scope and quality, as a dissertation for the degree of Doctor of Philosophy.

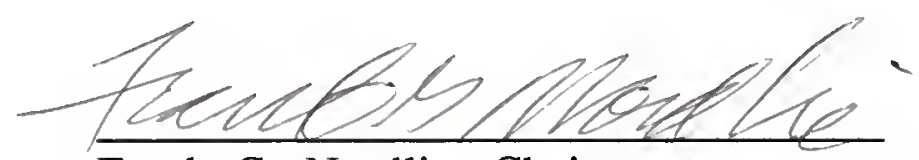

Frank G. Nordlie, Chairman

Professor of Zoology

I certify that I have read this study and that in my opinion it conforms to acceptable standards of scholarly presentation and is fully adequate, in scope and quality, as a dissertation for the degree of Doctor of Philosophy.

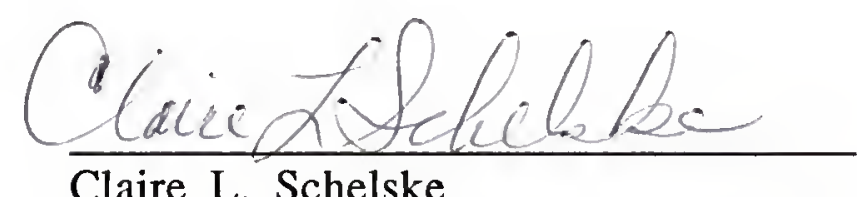

Claire L. Schelske

Carl S. Swisher Professor of Water Resources

I certify that $I$ have read this study and that in my opinion it conforms to acceptable standards of scholarly presentation and is fully adequate, in scope and quality, as a dissertation for the degree of Doctor of Philosophy.

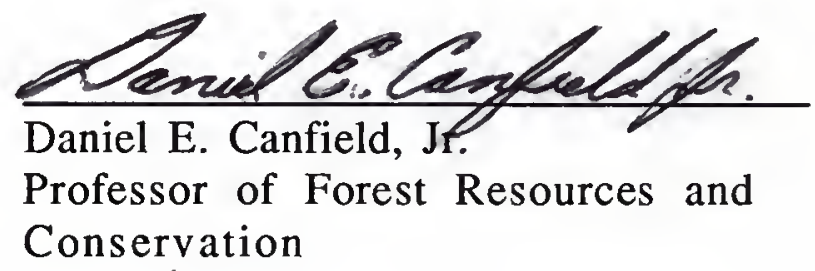


I certify that I have read this study and that in my opinion it conforms to acceptable standards of scholarly presentation and is fully adequate, in scope and quality, as a dissertation for the degree of Doctor of Philosophy.

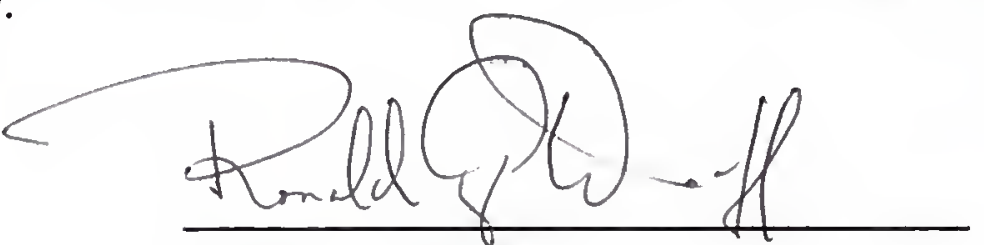

Ronald G. Wolff

Associate Professor of Zoology

I certify that I have read this study and that in my opinion it conforms to acceptable standards of scholarly presentation and is fully adequate, in scope and quality, as a dissertation for the degree of Doctor of Philosophy.

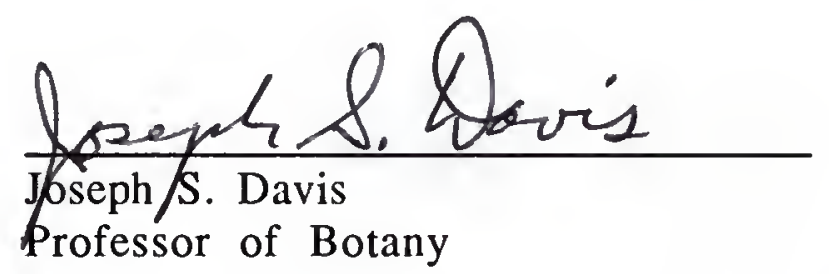

This dissertation was submitted to the Graduate Faculty of the Department of Zoology in the College of Liberal Arts and Sciences and to the Graduate School and was accepted as partial fulfillment of the requirements for the degree of Doctor of Philosophy.

May 1991

Dean, Graduate School 
UNIVERSITY OF FLORIDA

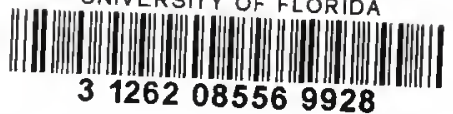

